Portland State University

PDXScholar

Fall 12-17-2018

\title{
Long-term Variation of Summer Phytoplankton Communities in an Urban Lake in Relation to Lake Management and Climate Conditions
}

Yuan Xiao Grund

Portland State University

Follow this and additional works at: https://pdxscholar.library.pdx.edu/open_access_etds

Part of the Environmental Sciences Commons, and the Social Psychology Commons Let us know how access to this document benefits you.

Recommended Citation

Grund, Yuan Xiao, "Long-term Variation of Summer Phytoplankton Communities in an Urban Lake in Relation to Lake Management and Climate Conditions" (2018). Dissertations and Theses. Paper 4728. https://doi.org/10.15760/etd.6612

This Thesis is brought to you for free and open access. It has been accepted for inclusion in Dissertations and Theses by an authorized administrator of PDXScholar. Please contact us if we can make this document more accessible: pdxscholar@pdx.edu. 
Long-term Variation of Summer Phytoplankton Communities in an Urban Lake in Relation to Lake Management and Climate Conditions

by

Yuan Xiao Grund

A thesis submitted in partial fulfillment of the requirements for the degree of

Master of Science

in

Environmental Science and Management

Thesis Committee:

Yangdong Pan, Chair

Eugene Foster

John Rueter

Mark Rosenkranz

Portland State University

2018 


\begin{abstract}
Eutrophication is one of the primary factors causing harmful cyanobacteria blooms in freshwater lakes; climate change such as warmer temperature can potentially further increase both frequency and intensity of blooms. This study investigated the long-term changes in water quality and summer phytoplankton assemblages in Oswego Lake, OR, in relation to lake management practices (e.g., hypolimnetic aeration and alum treatments), as well as climatic and regional meteorological conditions. Both water quality and phytoplankton assemblages were sampled biweekly during summer seasons between 2001 and 2013. The concentrations of total phosphorus (TP), soluble reactive phosphorus (SRP) and total nitrogen $(\mathrm{TN})$ decreased $66 \%, 93 \%$ and $31 \%$, respectively, in response to the hypolimnetic aeration and alum treatments since 2005 . The results of summer phytoplankton assemblages showed a $62 \%$ reduction of cyanobacteria biovolume and a switch from cyanobacteria dominance (2001-2005) to diatom and chlorophyte dominance (2006-2013). Cluster analysis identified four statistically different groups of summer phytoplankton assemblages (denoted Groups 1-4). Nonmetric multidimensional scaling analysis indicated that the four groups were associated with different water quality conditions. Group 1 occurred prior to hypolimnetic aeration and was primarily comprised of cyanobacteria, associated with water conditions of high nutrients and high primary production. Group 2, dominated by cyanobacteria and chlorophytes, occurred between hypolimnetic aeration and alum surface application. Group 2 was associated with turbid water conditions. Group 3 was dominated by diatoms, occurring after alum surface application. Group 4 included Rstrategist phytoplankton that quickly respond to environmental changes, occurring in the
\end{abstract}


years following alum injection, drawdown and inflow alum treatment. Both Group 3 and 4 were associated with reduced nutrients in the lake. The results demonstrated a strong temporal relationship between the long-term changes in water quality and summer phytoplankton assemblages and the lake management practices. The Pacific Decadal Oscillation (PDO) index, an El-Niño-like pattern of Pacific climate variability, showed a statistically significant correlation with the summer phytoplankton dynamics, while the multivariate ENSO index (MEI) and regional meteorological variables (air temperature, rainfall, wind speed, wind direction and solar radiation) were not significantly related to the changes of phytoplankton communities during the study period. In conclusion, the study results suggest that the lake management practices had strong effects on both production and community compositions of phytoplankton, and suggest the need for a future study on large-scale climate impacts on lake ecosystems and best management practice. 


\section{Acknowledgements}

I would like to express my deepest appreciation to my advisors:

Dr. Yangdong Pan, who has given me excellent guidance, encouragement and advice throughout my time as his student. I admire Dr. Pan a very kind and intelligent professor who constantly provides constructive suggestions in my coursework study, thesis research and my career, and who shows a passion for water science, has extensive knowledge of data analysis, and encourages my enthusiasm for science.

Dr. Eugene Foster, who cares for me and my thesis research and has continuously provided me with great support, guidance and encouragement. I am very grateful for Dr. Foster's support in providing me with a recommendation for my application to the master's program and helping me in literature reviews and setting up my thesis objectives during my early research.

Mark Rosenkranz, who inspires me with his excellent work attitude, and provides consistent support to my internship work and thesis research. I am very grateful for Mark's great support during my period of recovery from a broken leg and also during my pregnancy, and for Mark's sharing of his extensive knowledge on water quality management, which made the completion of my thesis possible.

Dr. John Rueter, who inspires me with his excellent teaching of Phytoplankton Ecology. I would also like to thank him for serving on my committee. 
Also, I would like to thank all the folks in the lab group for their time spent reviewing my thesis defense presentation and providing useful suggestions. I especially would like to give thanks to Dr. Joe Maser, Nicole Alfafara, Dr. Dan Sobota, Melinda Borgens, Erin Costello, Anna Withington, Dr. Patrick Edwards, Hannah Smiley, Bern Romey, and Dr. Nadia Gillett.

I must thank Lake Oswego Corporation for giving me the opportunity to do my internship work with them and providing funding which allowed me to undertake this research. I especially would like to give thanks to Mark Rosenkranz, Jeff Ward, Lillian Gehres, Madee Rubenson, Laurent Nickel, Sean Griffin, Gebe Winfrey, and Christina Stauffer.

Finally, I would like to give my whole hearted thanks to my husband Ted Grund, my son Nicholas Grund, Victoria Xiao, Brian Moelker, my parents and other family members. Special thanks to Ted for his support and encouragement, including proof reading of my writing, taking care of our son, and experiencing all of the ups and downs of my research. 


\section{Table of Contents}

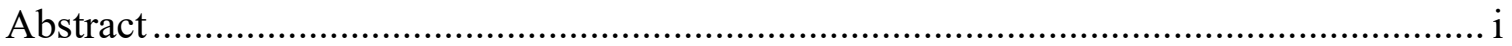

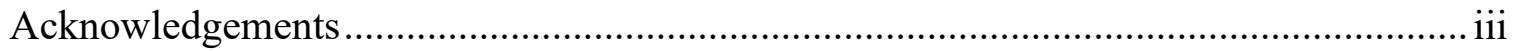

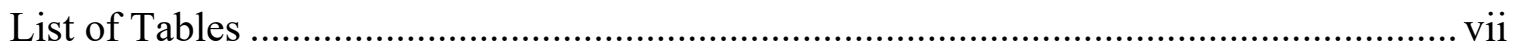

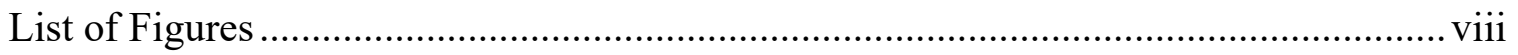

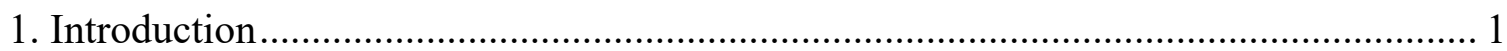

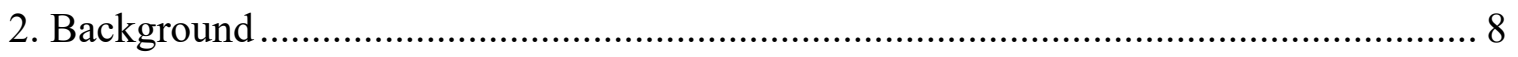

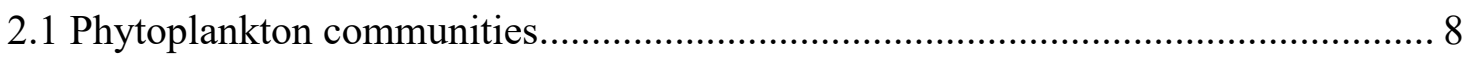

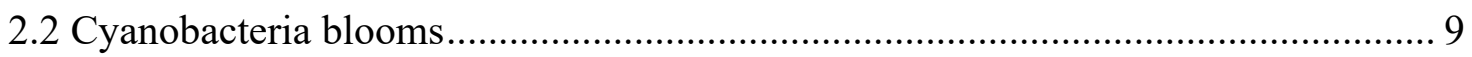

2.3 Effects of management and climate change on phytoplankton in urban ecosystems

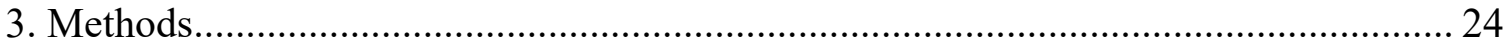

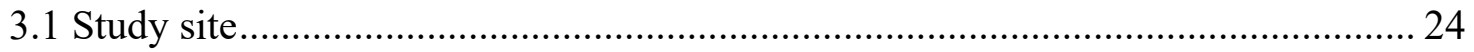

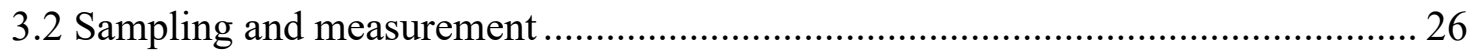

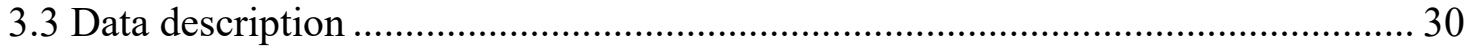

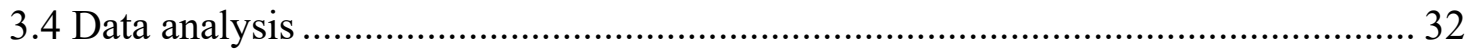

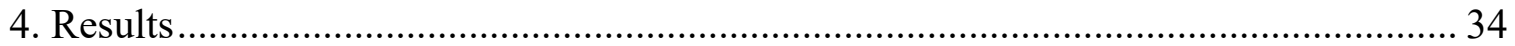

4.1 Changes of environmental conditions over 13 years ...................................... 34

4.2 Changes of phytoplankton assemblages in relation to environmental conditions .. 36

4.3 Changes of phytoplankton assemblages in relation to lake management practices 39

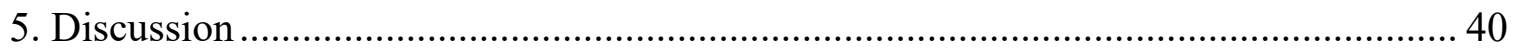

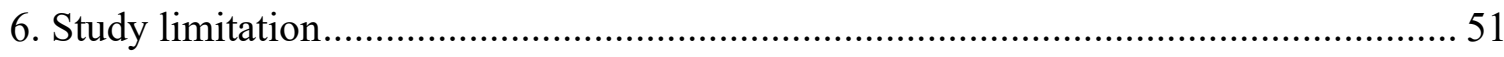

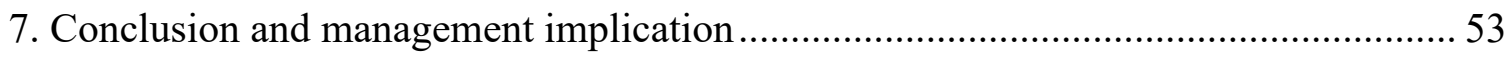

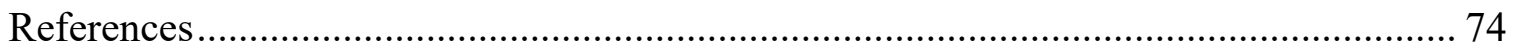

Appendix A: Water quality parameters between 2001 and 2013 in the deep basin of

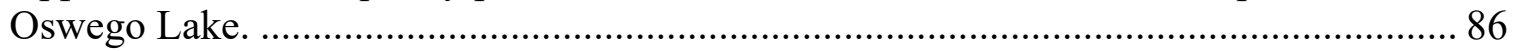

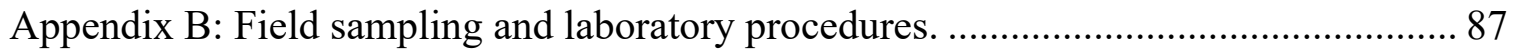


Appendix C: Wind rose diagram showing wind speed and wind direction across day time (5am - 9pm) between July and September from 2001 to 2013 at the weather station at Oswego Lake.

Appendix D: List of phytoplankton taxa and divisions. 95

Appendix E: Phytoplankton relative abundance between July and September from 2001 to 2013 in the deep basin of Oswego Lake.

Appendix F: Cluster dendrogram of phytoplankton assemblages showing four groups. . 98

Appendix G: Boxplots showing comparisons of the July-August-September means of epilimnetic TP, SRP and chlorophyll a for pre- and post-initial alum treatment in 2005.99

Appendix H: Time series of the multivariate ENSO index (MEI) and Pacific Decadal Oscillation (PDO) index between July and September from 2001 to 2013. 100

Appendix I: Time series of the multivariate ENSO index (MEI), showing the study period between 2001 and 2013 and two extreme El Niño events (1997-1998 and 2015-2016).101

Appendix J: Boxplots of cyanobacteria, epilimnetic water temperature and rainfalls between July and September from 2001 to 2013. 


\section{List of Tables}

Table 1: Morphometric characteristics of Oswego Lake.

Table 2: Major management practices implemented in Oswego Lake between 2001 and 2013

Table 3: Phytoplankton dominant taxa and indicator taxa of 4 groups based on the cluster analysis.

Table 4: Results from the environmental vectors fitting in the ordination space of the NMDS plot with variable scores along the two ordination axes (NMDS1-2), goodness-of-

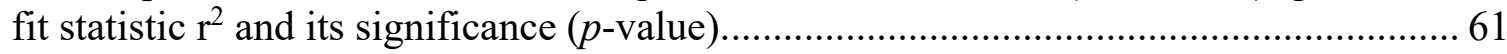




\section{List of Figures}

Figure 1: Conceptual diagram showing the major factors that affect cyanobacteria blooms.

Figure 2: Conceptual illustration of various approaches currently in use to control cyanobacteria blooms (from Paerl et al., 2016)

Figure 3: Location of Oswego Lake within its watershed.

Figure 4: Boxplots showing year-to-year variations of the selected environmental variables between July and September from 2001 to 2013 in the deep basin of Oswego

Lake.

Figure 5: Boxplots showing year-to-year variations of the phytoplankton assemblages among the major taxonomic groups between July and September from 2001 to 2013 in the deep basin of Oswego Lake.

Figure 6: Boxplots showing comparison of relative abundance of the phytoplankton taxonomic groups among 4 cluster groups based on the cluster analysis.

Figure 7: Plots of non-metric multidimensional scaling (NMDS) analysis showing temporal variation of the phytoplankton assemblages between July and September from 2001 to 2013 in the deep basin of Oswego Lake

Figure 8: Timeline of the lake management practices and the occurrence of the cluster groups based on phytoplankton assemblages between July and September from 2001 to 2013 


\section{Introduction}

Urban lakes have a high societal value, providing valuable access to water for local residents. However, increasing human population and urban development have substantially accelerated the eutrophication process in urban waterbodies (Birch \& McCaskie, 1999; J. W. Moore, Schindler, Scheuerell, Smith, \& Frodge, 2003). Urban watershed runoffs from diverse sources, such as wastewater treatment plants, fertilized residential lawns and impervious road surfaces, introduce large amount of nutrients, sediments and other contaminants to urban lakes (Carpenter et al., 1998; Roy et al., 2008). Consequently, many urban lakes have experienced algal blooms and reduced water quality associated with noxious odors, depletion of dissolved oxygen, cyanobacteria toxins, impaired recreation, and degraded drinking water supplies (Dodds et al., 2009; Heinzmann \& Chorus, 1994; Kotak et al., 1993; Oberholster, Botha, \& Cloete, 2006; Qin et al., 2010).

Excessive nutrient input is one of the primary causes of lake eutrophication that results in algal blooms (Huisman \& Hulot, 2005; Paerl et al., 2016; Schindler \& Vallentyne, 2008). Both nutrients, nitrogen $(\mathrm{N})$ and phosphorus $(\mathrm{P})$, are essential elements for the growth of phytoplankton, and they are usually limiting nutrients in control of phytoplankton growth in lakes (Butusov \& Jernelöv, 2013; Reynolds, 2006). Enrichment of N and P promotes the growth of phytoplankton in general (McCauley, Downing, \& Watson, 1989). Particularly, in lakes in temperate regions, during the summer growing season, $\mathrm{N}$ and $\mathrm{P}$ inputs were found to be responsible for the shift in phytoplankton communities towards dominance by cyanobacteria (Downing, Watson, \& McCauley, 2001; Watson, McCauley, 
\& Downing, 1997) and for the production of cyanobacteria toxins (Davis, Berry, Boyer, \& Gobler, 2009; Rapala, Sivonen, Lyra, \& Niemelä, 1997; Rolland, Bird, \& Giani, 2005).

In order to control algal blooms due to eutrophication, the greatest efforts have been made to reduce nutrients available to phytoplankton production (Ibelings, Bormans, Fastner, \& Visser, 2016; Paerl et al., 2016). Since certain cyanobacteria are able to fix atmospheric $\mathrm{N}$, management strategy for reduction of $\mathrm{P}$ is more feasible than that of $\mathrm{N}$ (Elser et al., 2007; Lewis, Wurtsbaugh, \& Paerl, 2011; Schindler et al., 2008).

Watersheds are the ultimate source of $\mathrm{P}$ input to lakes, so reduction in supply of $\mathrm{P}$ in watersheds is a sustainable approach to prevent blooms (Hamilton, Salmaso, \& Paerl, 2016). However, a great deal of evidences has shown that $P$ can remain in high concentrations in lake water after significant reduction of $\mathrm{P}$ from watershed loading, due to continued release of excess legacy P from lake sediments (Søndergaard, Jensen, \& Jeppesen, 2003; Van der Molen \& Boers, 1994). Ideally, reduction of nutrients to control algal blooms should focus on P in both watersheds and lake sediments (Cooke, Welch, Peterson, \& Nichols, 2005).

Control of algal blooms in urban lakes is a challenge (Birch \& McCaskie, 1999; Huser, Futter, Lee, \& Perniel, 2016). While reduction of nutrient loading can be partly achieved through watershed point-source permit management based on Total Maximum Daily Loads (TMDLs) according to the Clean Water Act (1972) (National Research Council, 1992), management of nutrient loading from non-point sources (NPS) is usually complex and difficult due to diverse NPS pollution that are transmitted via overland, underground and atmospheric paths and varies according to weather effects (Carpenter et al., 1998). 
Effective NPS management is based on best management practices (BMPs), such as development and maintenance of wetlands, retention ponds and vegetation buffer strips (Paerl et al., 2016). However, for urban lakes, those strategies often face implementation challenges, such as fragmented responsibilities in a single watershed and resistance to change in developed urban areas (Roy et al., 2008). For example, Aguiar et al. (2015) found that effective riparian buffer zones were about 12-meters in width, with woody vegetation removing $43 \%$ of TN and $36 \%$ of TP, shrubs $41 \%$ and $32 \%$, and grasses $21 \%$ and $17 \%$, respectively. However, especially in developed urban areas, it becomes very costly to change urban settings in order to retroactively construct riparian/wetland buffer zones (Huser, Futter, et al., 2016; Roy et al., 2008). Thus, in-lake management is more practical and cost efficient compared to watershed nutrient management in urban lakes (Huser, Futter, et al., 2016).

In-lake nutrient management mostly targets bioavailable phosphorus resuspended from sediments to the water column (Bormans, Maršálek, \& Jančula, 2016; Søndergaard et al., 2003; Van der Molen \& Boers, 1994). Hypolimnetic aeration and aluminum sulfate (alum) treatment are both traditionally and commonly used approaches to reduce $\mathrm{P}$ in urban lakes (Bormans et al., 2016; Huser, Egemose, et al., 2016; Welch \& Cooke, 1999). During periods of summer thermal stratification, hypolimnetic anoxia supports sediment phosphorus release to the water column (Søndergaard et al., 2003). Hypolimnetic aeration reduces hypolimnetic anoxia by increasing dissolved oxygen content of the hypolimnion without de-stratifying the lake (Soltero, Sexton, Ashley, \& McKee, 1994). Alum treatment of lake water forms aluminum hydroxide floc that is highly coagulated to phosphorus. It not only precipitates phosphorus from the water column, but also adsorbs 
and retains phosphorus from sediments when it settles down to the bottom, thus blocking internal phosphorus loading, which effect can last for about 13 to 15 years on average (Huser, Egemose, et al., 2016; Welch \& Cooke, 1999). Alum floc has high adsorption capacity and can directly adsorb and precipitate particles, such as cyanobacteria cells, from the water column (Cooke et al., 2005). Combined with hypolimnetic aeration technology to maintain oxic conditions above the sediments, phosphorus can be immobilized by alum in the sediments and become unavailable to fuel blooms (B. C. Moore et al., 2012). Furthermore, in the case where the major tributary to the lake contributes inflow water carrying high phosphorus loading, alum directly applied to the inflow water can remove phosphorus prior to discharge to the lake (Heinzmann \& Chorus, 1994; Pilgrim \& Brezonik, 2005).

Climate change poses new challenges for the control of algal blooms (Jöhnk et al., 2008; Paerl et al., 2016). Climate warming, resulting in warmer water temperatures, enhances the strength and duration of thermal stratification and increases internal nutrient loading, favoring buoyancy regulated cyanobacteria with optimal growth at warmer temperatures (often $>25^{\circ} \mathrm{C}$ ) (Kosten et al., 2012; Rigosi, Carey, Ibelings, \& Brookes, 2014; Robarts \& Zohary, 1987). Furthermore, climate warming increases variability in reginal meteorological conditions, such as extreme rainfall and extensive droughts, which modifies watershed hydrologic dynamics in increasing external nutrient loading, further favoring bloom formation (Paerl et al., 2016; Rigosi et al., 2014). Climate warming has been widely recognized as an important factor in the increased frequency and intensity of cyanobacteria blooms, and therefore, has an impact on current bloom control strategies (Kosten et al., 2012; Magnuson et al., 1997; Paerl \& Paul, 2012; Shimoda et al., 2011; 
Winder \& Sommer, 2012). For example, a physical bloom control approach, artificial mixing, had successfully controlled blooms of Microcystis, a cosmopolitan cyanobacterium of eutrophic freshwater, in Lake Nieuwe Meer, a recreational lake in the city of Amsterdam, since 1993 until an extreme summer heatwave occurred in Europe in 2003, the hottest summer recorded during the last century. During the experiment in Lake Nieuwe Meer in 2003, artificial mixing was switched on and off in order to reduce the energy costs of artificial mixing without inducing blooms. However, in August, at the peak of the summer heatwave, there were almost instant blooms of Microcystis as soon as artificial mixing was switched off, providing evidence that the heatwave, as a result of climate warming, promoted the bloom and caused the intermittent mixing strategies in control of the bloom to fail (Jöhnk et al., 2008). Intergovernmental Panel on Climate Change (IPCC, 2014) predicted that climate warming is unequivocal and is projected to rise $2.6-4.8^{\circ} \mathrm{C}$ over the $21^{\text {st }}$ century. Although the interaction effect between eutrophication and climate change on cyanobacteria blooms is still uncertain, the general understanding is that eutrophication and climate change act as two key factors favoring the blooms (Carey, Ibelings, Hoffmann, Hamilton, \& Brookes, 2012; Kosten et al., 2012; Paerl \& Huisman, 2008; Rigosi et al., 2014). Bloom management cannot be successful without properly addressing the challenges of both nutrients and climate conditions in favoring bloom occurrence.

Our understanding of phytoplankton communities in response to nutrient management practices and climate change is insufficient. Many studies have reviewed the efficacy of bloom control practices (e.g., hypolimnetic aeration and alum treatment), but most evaluations were based on a single approach and the short-term effects on nutrient 
concentrations, chlorophyll $a$ and/or total phytoplankton abundance (Huser, Futter, et al., 2016; Suikkanen, Laamanen, \& Huttunen, 2007). Reports of integrated multiple practices are only available for a few lakes (B. C. Moore \& Christensen, 2009; Soltero et al., 1994). The responses of phytoplankton communities were often reported briefly, probably due to lack of long-term, comparable data of taxonomic identifications for phytoplankton species (Suikkanen et al., 2007). Changes of phytoplankton compositions usually indicate shifts in environmental conditions (Reynolds, 2006). In perspective of the goal of nutrient management in control of blooms, the responses of phytoplankton communities to the changes of environmental conditions is more informative. In addition, previous studies have found the impacts of large-scale climatic events, such as El Niño Southern Oscillation (ENSO) and Pacific Decadal Oscillation (PDO), on phytoplankton community dynamics (Harris \& Baxter, 1996; McGowan, Patoine, Graham, \& Leavitt, 2005; Winder \& Schindler, 2004; Winder \& Sommer, 2012). But the significant climatic effects were related to phytoplankton spring communities and annual succession patterns, less focused on summer growing seasons. Furthermore, large-scale climatic events can modify reginal meteorological conditions that can possibly impact summer phytoplankton in long-term aspect (McGowan et al., 2005). Therefore, study of climate change focusing on summer phytoplankton communities is helpful to understand climate influence on summer cyanobacteria blooms and provides implications for bloom mitigation.

In this study, I characterized the changes in summer phytoplankton assemblages and their relationships with environmental variables in Oswego Lake, an urban lake in Oregon, USA, over a 13-year period (2001-2013). Specifically, I want to (1) characterize the 
changes in summer phytoplankton assemblages in terms of dominant species and indicator species; (2) relate the changes of phytoplankton communities to water quality, lake management practices, large-scale climatic conditions, using the multivariate ENSO index (MEI) and PDO index, and regional meteorological conditions characterized by air temperature, rainfall, wind speed, wind direction and solar radiation. I therefore hypothesized that lake management practices, large-scale climatic conditions and regional meteorological conditions would have effects in driving the changes of phytoplankton communities, with nutrient-targeted management practices expected to have stronger influence on water quality and phytoplankton than climate and meteorological conditions. With the purpose of understanding the basic response mechanism of phytoplankton communities to lake management and climate change, this study may provide important information for future urban lake management to effectively predict, prevent and control harmful cyanobacteria blooms. 


\section{Background}

\subsection{Phytoplankton communities}

Phytoplankton is the foundation of the aquatic food web, and phytoplankton communities are diverse and dynamic, spatially and temporally, in aquatic habitat (Hutchinson, 1961; Reynolds, 2006; Sommer, Gliwicz, Lampert, \& Duncan, 1986). The dynamics of phytoplankton communities is the outcome of phytoplankton species competitions for light and nutrients, and of avoidance from grazing, determined by species-specific biological features and growth mechanics. For example, Sommer et al. (1986) used the Plankton Ecology Group (PEG) model to describe the annual succession pattern of phytoplankton composition and abundance due to seasonal changes of temperature, nutrient fluxes, light availability and grazing pressure. Furthermore, Reynolds (2006) and other ecologists developed the idea that the predominant community species are predictable in relation to their habitat characteristics because the most-favored species traits, survival strategies and community assemblages will occur (Grime, 1977; Keddy, 1992; Southwood, 1977). Changes of phytoplankton community compositions usually indicate shifts in environmental conditions (Reynolds, 2006). 


\subsection{Cyanobacteria blooms}

Cyanobacteria are the oldest known fossil organisms, possibly dated back to 3.5 million years ago (Golubic \& Seong-Joo, 1999). They are highly diverse photosynthetic bacteria in unicellular or multicellular forms, living in freshwater, ocean, and terrestrial environments (Whitton \& Potts, 2007). Cyanobacteria are generally considered to beneficially contribute to photosynthesis and nitrogen fixation and they perform an important ecosystem function as primary producers in many food chains (Whitton \& Potts, 2007). However, certain cyanobacterial genera, such as Microcystis, Anabaena (recently renamed Dolichosermum) and Oscillatoria, can produce toxins (cyanotoxins) that are harmful to human health, other organisms and the environment (Carmichael, 1997). Harmful cyanobacteria blooms are a severe problem with rapidly increasing worldwide concerns due to their negative impacts on water quality, human health and ecosystem as well as the complexity of their prevention and remediation (Dodds et al., 2009; Kosten et al., 2012; Paerl \& Huisman, 2008).

Understanding the environmental factors causing cyanobacteria's successful growth and increasing presence in water bodies is essential to effectively predict, prevent and control cyanobacteria blooms. It is no surprise that a great number of research projects and studies have been conducted to identify the causative factors that contribute to cyanobacteria blooms. No single factor drives cyanobacteria blooms; in reality, it is due to the complex combination and interactions of physical, chemical and biological phenomena that favor the establishment of blooms (Kosten et al., 2012). In general, the 
growth of cyanobacteria favors nutrient-rich, high water temperature, sufficient light, low $\mathrm{CO}_{2} /$ high $p \mathrm{H}$, and stratified water conditions (Figure 1).

The enrichment of nutrients, primarily nitrogen and phosphorus, in freshwater lakes is responsible for cyanobacteria blooms (Huisman \& Hulot, 2005; Paerl et al., 2016). Nitrogen and phosphorus are both essential elements for growth of phytoplankton. Nitrogen is a major component of chlorophyll $a$ and amino acids, while phosphorus is a fundamental building block of cell membranes, DNA and RNA, and ATP and ADP (Butusov \& Jernelöv, 2013; Reynolds, 2006). They are both usually considered as limiting nutrients in control of phytoplankton growth in lakes (Reynolds, 2006). However, some cyanobacteria are able to fix atmospheric nitrogen and nitrogen fixation can be sufficient to support phytoplankton growth; thus, phytoplankton growth in lakes is more likely limited by phosphorus (Schindler et al., 2008).

Cyanobacteria growth is warm temperature-dependent. Paerl and Huisman (2008) used vivid language, "Blooms like it hot", to describe cyanobacteria metabolism requirement of warm temperature. Thus, blooms often form in summer in temperate freshwater lakes. Although different cyanobacteria species response to temperature in various degrees, higher growth rates are generally observed in higher water temperature conditions, until optimal temperature value is reached because each species has its own set of temperature range that it can tolerate. Robarts and Zohary's (1987) analysis showed that cyanobacteria has accelerating growth rate between 25 and $40{ }^{\circ} \mathrm{C}$ based on a large number of published field and laboratory data. Warmer water temperature is a favorable condition for growth of cyanobacteria in general. 
Cyanobacteria perform photosynthesis and utilize light energy to fix carbon dioxide to self-supply nutrients for life activities. Therefore, light availability is essential to the growth of cyanobacteria. Cyanobacteria have two mechanisms that enable them to effectively harvest light as a result of adaption to environment: pigmentation and buoyancy (Carey et al., 2012; Reynolds, 2006). Cyanobacteria contain photosynthetic pigments of chlorophyll $a$ and phycobiliproteins. Chlorophyll $a$ that is common in phytoplankton absorbs wavelengths of $400-450 \mathrm{~nm}$ and $650-700 \mathrm{~nm}$. In addition to chlorophyll $a$, cyanobacteria have phycobiliproteins to absorb wavelength of 400-650 nm that is more prevalent in deeper water (Glazer, 1997), resulting in greater efficiency in light capturing for photosynthesis than other phytoplankton. Cyanobacteria also contain gas vesicles that allow cyanobacteria to regulate buoyancy in the vertical water column to uptake light in epilimnion and nutrients in hypolimnion during summer stratification (Reynolds, Oliver, \& Walsby, 1987). The buoyancy-regulation mechanism benefits cyanobacteria in competition with other phytoplankton (Reynolds et al., 1987; Walsby, 1994).

The low $\mathrm{CO}_{2} /$ high $p \mathrm{H}$-hypothesis by King (1970) states that cyanobacteria are more efficient in obtaining carbon dioxide than phytoplankton. Photosynthetic activity makes strong demands on carbon dioxide. As photosynthesis increases, dissolved carbon dioxide in water decreases, resulting in increased water $p \mathrm{H}$. Reduced supply of dissolved carbon dioxide can be a limiting factor in the growth of phytoplankton. However, cyanobacteria have evolved an effective photosynthetic $\mathrm{CO}_{2}$ concentrating mechanism (CCM) that is perhaps the most effective $\mathrm{CO}_{2}$-uptake mechanism in any photosynthetic organism (Badger \& Price, 2003). Shapiro (1997) manipulated Squaw Lake, Wisconsin 
by injection of carbon dioxide for a study of the relationship between carbon dioxide and cyanobacteria. The result of this study suggests that the growth of cyanobacteria is not dependent on the condition of low $\mathrm{CO}_{2} /$ high $p \mathrm{H}$, but rather that cyanobacteria are able to continually grow in conditions of low $\mathrm{CO}_{2} /$ high $p \mathrm{H}$ in which the growth of most phytoplankton is limited. The continuing growth of cyanobacteria extends the decreasing rate of dissolved carbon dioxide, and therefore maintain their dominance over other phytoplankton.

Summer vertical thermal stratification in freshwater system favors cyanobacteria. The stability of water is resistant to vertical mixing of epilimnion and hypolimnion, and this resistance is due to water density gradients that are induced by water temperature (Wetzel, 2001). Cyanobacteria are able to regulate buoyancy in the water column, which allows them to obtain light in epilimnion and nutrient in hypolimnion. Cyanobacteria blooms form thick layer scums at the surface of water as a canopy, attenuating light penetration into the water, which suppresses non-buoyant phytoplankton and enhances their domination in the water system (Paerl \& Huisman, 2008). However, artificial mixing, as an example, increases turbulence in water and reduces water stability, which results in cyanobacteria losing their advantage of buoyancy (Visser, Ibelings, Bormans, \& Huisman, 2016).

Cyanobacteria abundance is directly regulated by aquatic food web structure (Shapiro, Lamarra, \& Lynch, 1975). Phytoplankton is a primary producer, while zooplankton and phytoplanktivorous fish are primary consumers of phytoplankton (Reynolds, 2006). However, planktivorous fish, feeding on zooplankton, usually allow opportunity for the 
growth of phytoplankton; on the contrary, piscivorous fish, feeding on planktivorous fish, increase grazing pressure of zooplankton on phytoplankton (Reynolds, 2006). This trophic structure has been well studied theoretically, such as in the Trophic Cascade Model (Carpenter, Kitchell, \& Hodgson, 1985) and the Top-down or Bottom-up Theory (Horppila, Peltonen, Malinen, Luokkanen, \& Kairesalo, 1998), and practically in biomanipulation management on control of cyanobacteria blooms (Triest, Stiers, \& Onsem, 2016). Interestingly, cyanobacteria can produce mucilage and/or toxin, and form large colonies or filaments in resistance to grazing. For instance, Drenner et al. (2002) reported that although the stocking of piscivorous fish increased zooplankton abundance and decreased phytoplankton density, the phytoplankton dominant community shifted to inedible cyanobacteria.

Watershed land use types have been acknowledged as a strong factor to freshwater phytoplankton structure (Katsiapi, Mazaris, Charalampous, \& Moustaka-Gouni, 2012; Paul et al., 2012). Previous studies suggest that urban lakes are generally more prone to have cyanobacteria blooms than non-urban lakes (Katsiapi et al., 2012; Schueler \& Simpson, 2001). Urban lakes tend to be rather small and shallow with large watershed to lake area ratio, indicating that their watersheds exert a strong influence on the lakes (Schueler \& Simpson, 2001). Urban watersheds are often areas draining water from wastewater treatment plants, fertilizers from golf course and residential lawns, and storm run-off from impervious cover into the lake, introducing great amount of nutrients, sediments and other contaminants to the lakes (Carpenter et al., 1998; Roy et al., 2008). External loading leads to increasing sedimentation of nutrients and organic materials in 
lakes and subsequently reinforcing internal cycling of nutrients, fueling cyanobacteria blooms (Søndergaard et al., 2003).

Climate warming has the potential to directly affect the physical, chemical, and biological characteristics of lakes, and to indirectly affect lakes through its influences on watershed ecosystem. "Blooms like it hot" (Paerl \& Huisman, 2008) suggests that cyanobacteria eventually benefit from the consequences of global warming. Temperature increase driven by global warming extends the period of stratification, which is a favorable condition for cyanobacteria growth (Livingstone, 2003; Livingstone \& Dokuli, 2001; Magnuson et al., 1997; Shimoda et al., 2011; Winder \& Schindler, 2004). Severe occurrences of precipitation and drought driven by climate change also lead to favorable condition for cyanobacteria growth (Carey et al., 2012; Paerl \& Huisman, 2008; Reichwaldt \& Ghadouani, 2012; Settele et al., 2014). For example, heavy storms increase the turbidity of a water body by causing suspension of sediment in the water and flushing ambient sediment into the water. This condition disturbs cyanobacteria communities in the short-term, however, favor cyanobacteria growth in the long-term (Reichwaldt \& Ghadouani, 2012). 
2.3 Effects of management and climate change on phytoplankton in urban ecosystems

\subsubsection{Approaches for managing cyanobacteria blooms}

There are a number of methods for preventing, controlling and mitigating cyanobacteria blooms, and many case studies of the success or failure of these methods have been well documented (Ibelings et al., 2016; Paerl et al., 2016) (Figure 2). Bloom management is usually at first based on limiting the availability of nutrients for cyanobacteria development (Cooke et al., 2005; McCauley et al., 1989; Schindler \& Vallentyne, 2008), because the enrichment of nutrients, primarily nitrogen $(\mathrm{N})$ and phosphorus $(\mathrm{P})$, in freshwater lakes is responsible for cyanobacteria blooms (Huisman \& Hulot, 2005; Paerl et al., 2016). Both $\mathrm{N}$ and $\mathrm{P}$ are usually considered to be limiting nutrients in control of phytoplankton growth in lakes (Reynolds, 2006). However, some cyanobacteria are able to fix atmospheric $\mathrm{N}$; thus, phytoplankton growth in lakes is more likely limited by $\mathrm{P}$ (Schindler et al., 2008). The 16-year long experiment of a whole-lake nutrient enrichment by Schindler et al. (2008) demonstrated that $\mathrm{P}$ was the limiting nutrient alone and $\mathrm{N}$ reduction induced the growth of $\mathrm{N}$-fixing cyanobacteria. Although other studies showed that $\mathrm{N}$ reduction in control of blooms was equally important due to consideration of downstream eutrophication in $\mathrm{N}$ sensitive estuarine and coastal waters (Elser et al., 2007; Lewis et al., 2011), nutrient management in lakes to control blooms is usually focused on P first.

A number of studies have shown that $\mathrm{P}$ remained at high concentrations in the water column after significant reductions of $\mathrm{P}$ from watershed loading, which was due to 
continued release of excess legacy P from lake sediments (Søndergaard et al., 2003; Van der Molen \& Boers, 1994). Internal recycling of phosphorus plays an important role in natural processes of lakes, because phosphorus is an essential nutrient to organisms and has been recognized as the least abundant element in comparison to other major nutrients, such as carbon, hydrogen, nitrogen, oxygen, and sulfur (Wetzel, 2001). Exchange of phosphorus between sediments and the overlying water continuously occurs in lakes. Particulate phosphorus in water slowly sinks to the bottom, while dissolved phosphorus is absorbed quickly by bacteria, algae and plants in the water column and eventually deposits as organic detritus to the sediments. Simultaneously, phosphorus in sediments returns to the water under an array of physical, chemical and biological processes. This release of phosphorus from sediments is generally called internal loading to be distinguished from external loading. Dissolved phosphorus diffuses across the sedimentwater interface physically due to concentration gradients. Also, the movement of benthic invertebrates and fish results in disturbance of sediments, which generates resuspension of phosphorus particulate to the water. Similarly, wind-induced turbulence, typically in shallow lakes, can cause phosphorus resuspension as well. During summer in deep stratified lakes, phosphorus can release from sediments to the water as a result of redox reactions under anoxic condition, in which iron (III) reduce to iron (II) and release bonded phosphate to soluble forms. Some phytoplankton species contribute phosphorus recycling when they migrate from their resting stage in the sediment to life stage in the water (Pettersson, 1998). More detailed processes of internal phosphorus loading are illustrated by Wetzel (2001). Among various mechanisms of internal phosphorus loading, chemical equilibria process contributes the most significant release in comparison to other processes (Wetzel, 2001). Among various lake management 
practices in control of internal phosphorus loading, applications of alum and hypolimnetic aeration have been found the effective methods in precipitation and inactivation of phosphate in sediments.

\subsubsection{Alum}

Alum represents a group of aluminum salts. Alum commonly used as a clarifying agent (coagulation-flocculation reactant) of water is aluminum sulfate $\left(\mathrm{Al}_{2}\left(\mathrm{SO}_{4}\right)_{3}\right)$ (Cooke et al., 2005). Alum is soluble in water. When alum is applied to water, the aluminum ion dissociates in water and undergoes a series of hydrolysis reactions. Aluminum hydrolysis reactions are $p \mathrm{H}$ dependent. Large colloidal floc of aluminum hydroxide $\left(\mathrm{Al}(\mathrm{OH})_{3}\right)$ is the predominant product between $p \mathrm{H} 6$ and 8 , while soluble $\mathrm{Al}(\mathrm{OH})_{2}{ }^{+}$and $\mathrm{Al}^{3+}$ occur at lower $p \mathrm{H}$ and soluble $\mathrm{Al}(\mathrm{OH})_{4}{ }^{-}$occurs at higher $p \mathrm{H}$ (Cooke et al., 2005). Thus, the reactions between alum and phosphorus are also $p \mathrm{H}$ dependent. At low $p \mathrm{H}$, such as sewage water, phosphorus is removed from the water column primarily by precipitation of $\mathrm{AlPO}_{4}$. But in lakes, usually with higher $p \mathrm{H}$, phosphorus and particles are primarily removed by coagulation and flocculation process of formation of aluminum hydroxide floc (Cooke et al., 2005). It is very important to determine the optimal dosage of alum in treatment because excessive additions of alum will decrease $p \mathrm{H}$ and increase soluble aluminum forms, including $\mathrm{Al}(\mathrm{OH})_{2}{ }^{+}$and $\mathrm{Al}^{3+}$, producing toxic effects to aquatic systems (Gensemer \& Playle, 1999). The treatment dose can be estimated based on $p \mathrm{H}$ and alkalinity of the lake water and mobile phosphorus (iron bonded phosphorus and loosely attached phosphorus under anoxic condition) in the sediment (Cooke et al., 2005). In order to buffer $p \mathrm{H}$ in alum treatment, sodium aluminate $\left(\mathrm{NaAlO}_{2}\right)$ is usually added with 
alum content. The buffered treatment can maintain a $p \mathrm{H}$ between 6 and 8 and enhance phosphorus removal (Cooke et al., 2005).

Alum surface application was the first (Jernelov, 1970) and most commonly used method (Schütz, 2016), which allows aluminum flocs to precipitate phosphorous through the entire water column and to inactivate phosphorus in the sediments by forming a barrier to the release of sediment phosphorus. Aluminum hydroxide floc is highly coagulated to phosphorus. It not only precipitates phosphorus from the water column, but also adsorbs and retains phosphorus from sediments when it settles to the bottom, thus blocking internal phosphorus loading, with the effect lasting for more than 10 years (Cooke et al., 2005). Alum floc has high adsorption capacity and can directly adsorb and precipitate particles, such as cyanobacteria cells from the water column (Cooke et al., 2005). Later, the alum hypolimnetic injection method was developed to directly target sediments, the source of internal phosphorus loading, and lower the adverse effects on aquatic organisms (Cooke et al., 2005). One-time alum treatment applied to whole lake was usually employed with a large dose in order to apply adequate aluminum to bond phosphorus in both water and sediments (Cooke et al., 2005). However, the effectiveness of phosphorus inactivation is reduced not only by decreasing adsorption capacity of aluminum floc, but also by burial of active Al-P layer due to new sedimentation and sediment mixing process (Cooke et al., 2005; Lewandowski, Schauser, \& Hupfer, 2003). Successive low-dose application has been developed for the purpose of maintaining aluminum floc for high effectiveness (Cooke et al., 2005; Lewandowski et al., 2003; B. C. Moore, Christensen, \& Richter, 2009). In the case where the major tributary to the lake contributes the inflow water carrying high phosphorus loading, alum directly applied 
to the inflow water can remove phosphorus prior to discharge to the lake (Heinzmann \& Chorus, 1994; Pilgrim \& Brezonik, 2005).

Alum treatment has been commonly used to reduce internal phosphorus loading in lakes of the United States and other countries (Huser, Egemose, et al., 2016; Welch \& Cooke, 1999). The review by Welch and Cooke (1999) on alum effectiveness showed that total phosphorus was reduced by an average of $37 \%$ (ranged from $13 \%$ to $65 \%$ ) and chlorophyll $a$ decreased by an average of $57 \%$ (ranged from $28 \%$ to $75 \%$ ), as results of alum treatments to 7 out of 7 stratified lakes. Huser et al. (2016) further analyzed 114 lakes treated with alum and reported that total phosphorus was reduced by an average of $64 \%$ and chlorophyll $a$ decreased by an average of $62 \%$. Both studies suggest that alum treatment overall is effective in controlling in-lake phosphorus and improvement of water quality based on reduction of chlorophyll $a$ concentration.

\subsubsection{Hypolimnetic aeration}

Hypolimnetic anoxia supports sediment phosphorus release to the water column. Hypolimnetic aeration reduces hypolimnetic anoxia by increasing dissolved oxygen content of hypolimnion without de-stratifying the lake (Cooke et al., 2005; Soltero et al., 1994). Hypolimnetic aeration can be accomplished by injection of oxygen or air into hypolimnion. The air-lift aerators, especially the partial air-lift aerators, were commonly used (Soltero et al., 1994). Hypolimnetic aerators receive compressed air at the lake bottom, transport the bottom water up by rising air bubbles and increase dissolved oxygen content in water through the gradient of dissolved oxygen, then return the aerated 
water to the lake bottom and release excess air to the lake surface (Cooke et al., 2005; Soltero et al., 1994).

Hypolimnetic aeration has been used for a number of lakes and reservoirs to reduce blooms and improve water quality. Cooke et al. (2005) reviewed 28 cases and found that hypolimnetic aeration resulted in an increase of hypolimnetic dissolved oxygen (DO) in most cases, often to at least $7 \mathrm{mg} \mathrm{DO} / \mathrm{L}$. For example, in Newman Lake, alum addition along with hypolimnetic aeration had improved control of internal P loading (Moore et al., 2012). However, Cooke et al. (2005) found that hypolimnion aeration was not as effective as alum in the reduction of hypolimnetic phosphorus, which might be due to lack of P-binding agents, such as Fe, Mn or Al.

\subsubsection{Effects of climate change on phytoplankton}

Climate warming has the potential to directly affect physical, chemical, and biological characteristics of lakes, and to indirectly affect lakes through its influences on the watershed ecosystem (Kosten et al., 2012; Paerl et al., 2016; Rigosi et al., 2014; Robarts \& Zohary, 1987). Intergovernmental Panel on Climate Change (IPCC) defines climate change as a testable change of climate over an extended period, typically decades or longer, due to natural variability and/or human activity (IPCC, 2007). According to IPCC AR5 (IPCC, 2014), warming of the climate system is unequivocal and a changing climate is having widespread impacts on human and natural systems. Lake surface water temperature is closely correlated with air temperature. Previous studies have showed that warmer air temperatures resulted in warmer epilimnetic temperature, longer duration of 
summer stratification, stronger stability of thermal stratification, and deeper thermocline depth (Livingstone, 2003; Livingstone \& Dokuli, 2001; Magnuson et al., 1997; Shimoda et al., 2011; Winder \& Schindler, 2004). Climate effects on nutrients are complex because climate has effects on physical, chemical and biological processes of nutrient cycles. For example, prolonged and stable stratification will result in hypolimnetic anoxia that increase internal phosphorus loading (Carey et al., 2012; Settele et al., 2014). At the catchment level, warming stimulates rock weathering and soil erosion, and intensified precipitation due to warming increases runoff of sediments and nutrients to the receiving lakes (Carey et al., 2012; Paerl \& Huisman, 2008; Reichwaldt \& Ghadouani, 2012). Climate change, characterized by conditions such as rising temperature and changing precipitation patterns, causing extreme weather conditions like storms and droughts, modifies the abiotic and biotic environment favorable to the growth of cyanobacteria (Reichwaldt \& Ghadouani, 2012). Bloom-forming cyanobacteria contain gas vacuoles that allow cyanobacteria to regulate buoyancy in the vertical water column to uptake light in epilimnion and nutrients in hypolimnion during summer stratification (Carey et al., 2012). Cyanobacteria also have greater growth rate than other phytoplankton in warmer water temperature conditions (Paerl \& Huisman, 2008). Increasing water temperature results not only in boosting the growth of cyanobacteria but also increasing strength and duration of summer stratification, thus, enhancing bloom formation (Carey et al., 2012; Elliott, 2010; Jöhnk et al., 2008; Settele et al., 2014). The El Niño Southern Oscillation (ENSO) is the most important large-scale hydrometeorological phenomenon that contributes to extreme climatic events on interannual time scales (Wolter, 1989). Multivariate ENSO index (MEI) is a method used to characterize ENSO events in the first principal component of six observed variables over 
the tropical Pacific Ocean (sea level pressure, surface zonal and meridional wind components, sea surface temperature, surface air temperature, and cloudiness), based on long-term marine records from the Comprehensive Ocean-Atmosphere Data Set (COADS) (Wolter \& Timlin, 1993, 1998). It is computed every month, averaging monthly means into bimonthly seasons (Dec/Jan, Jan/Feb, ... Nov/Dec). The positive values of MEI represent the warm ENSO phase (El Niño), while the negative values of MEI represent the cold ENSO phase (La Niña). According to Mazzarella et al. (2010), MEI was the most representative meteorological index for ENSO compared to other indices. The effects of ENSO on lake ecosystems have been observed in North America (Harris \& Baxter, 1996; McGowan et al., 2005; Winder \& Schindler, 2004). For example, McGowan et al.'s (2005) study of six lakes in Saskatchewan, Canada suggests that the maximum summer phytoplankton abundance in 1997 was consistent with the very strong 1997 El Niño (Wolter \& Timlin, 1998).

The Pacific Decadal Oscillation (PDO) is another large-scale climate phenomenon that has an impact on the surface air temperature and precipitation of western North America (Mantua, Hare, Zhang, Wallace, \& Francis, 1997). The PDO has been described as an ENSO-like pattern of Pacific climatic fluctuation, but distinguished from ENSO by 1) the persistence for more than two decades during the $20^{\text {th }}$ century while typical ENSO events persist for 6 to 18 months; 2) the influences particularly in the North Pacific while ENSO's influences are in tropics; and 3) unclear mechanisms casing PDO while causes for ENSO variability were well-known (Mantua \& Hare, 2002). The PDO index is defined as the leading principal component of North Pacific monthly sea surface temperature variability (Mantua \& Hare, 2002). Positive PDO index indicates warm 
phase, while negative PDO index indicates cool phase. The effects of PDO on the Northwest North America is that the conditions of warm temperature and low precipitation are associated with the warm PDO phase, while the opposite conditions are associated with the cool PDO phases (Mantua \& Hare, 2002). The PDO has been associated with ecological variabilities, such as salmon production (Mantua et al., 1997), lake ice cover (Bonsal, Prowse, Duguay, \& Lacroix, 2006), lake water level (Peterson, Silsbee, \& Redmond, 1999), and plankton community dynamics (Winder \& Schindler, 2004; Winder \& Sommer, 2012). For example, the long-term study (a period of 40 years from 1962 to 2002) of climatic effects on phytoplankton pattern in Lake Washington (about $300 \mathrm{~km}$ north of Oswego Lake) showed significant effects of large-scale meteorological phenomena, including PDO and ENSO, on the phytoplankton spring blooms through its effect of warming on the extended duration of lake stratification (Winder \& Schindler, 2004; Winder \& Sommer, 2012). 
3. Methods

3.1 Study site

Oswego Lake $\left(45^{\circ} 24^{\prime} 34^{\prime \prime} \mathrm{N}, 122^{\circ} 41^{\prime} 47^{\prime \prime} \mathrm{W}\right)$ is located in northwest Oregon, approximately $13 \mathrm{~km}$ south of the city of Portland. The lake, a former channel of the Tualatin River, was formed by the Missoula Floods of the last ice age, rich in flood sediments that were deposited in the lake bed (Foster, 2009). The lake area was rich in iron ore, and ore mining and smelting was the central industry in the lake town in the mid-1800s. The lake was dammed for power generation and the area surrounding the lake was developed as a residential district in the 1900s. Now the lake consists of one deep basin, two shallow basins and two canals (Figure 3 ). It has a maximum depth of $16.7 \mathrm{~m}$ and a total area of $1.7 \mathrm{~km}^{2}$ (Table 1). The lake's flow system includes one outflow, three inflows, and almost 70 storm water outfalls in its watershed. The lake has a watershed area of 18.6 $\mathrm{km}^{2}$ entirely within the limits of the city of Lake Oswego. The watershed is mostly comprised of urban areas $(68 \%)$ and forest cover $(19 \%)$. The climate in the region is characterized by wet, mild winters and dry, warm summers, directly affected by the Pacific Ocean (Franczyk \& Chang, 2009). Between 2001 and 2013, the average monthly temperatures ranged from a low of $4.2^{\circ} \mathrm{C}$ in December to a high of $20.2^{\circ} \mathrm{C}$ in July, and the average annual precipitation was $962.1 \mathrm{~mm}$. More than $70 \%$ of the annual precipitation was during October through March, with less than 10\% falling between July and September. 
Oswego Lake was previously a hypereutrophic lake and had a long history of cyanobacteria blooms (D. M. Johnson, 1985). Since the 1950's the full water right of 1.6 $\mathrm{m}^{3} \mathrm{~s}^{-1}$ had been withdrawn from the Tualatin River 24 hours a day, year-round to the lake for power generation. Although this practice was reduced since the mid 1990's, the inflow of nutrient-rich Tualatin River water resulted in bringing in large loads of phosphorus-rich sediments into the lake (ODEQ, 2001). For example, from November 1986 to December 1987, 38.9 million cubic meters of water were imported from the Tualatin River, with a loading of $487,000 \mathrm{~kg}$ sediment and $14,000 \mathrm{~kg}$ phosphorus (SRI, 1987). Oswego Lake is also the destination for the surface run-off from the local watershed managed by the City of Lake Oswego. Additionally, in 1996, the lake experienced a major flood that contributed a great deal of sediment from the Tualatin River. As a result, there was a large reservoir of phosphorus-rich sediment in the lake, which caused significant summer algae growth. A Microcystis bloom during late summer 2004 necessitated restricting lake use to non-contact activities because of the potential for illness due to the presence of microcystin toxin.

A number of management practices have been employed in Oswego Lake to reduce and prevent cyanobacteria blooms. Prior to 2001, copper sulfate was used to the lake to reduce the algae concentration. This practice was stopped in 2001 because of the possible adverse effects on the aquatic environment. Between 2001 and 2013, the primary management effort was focused on reduction of in-lake phosphorus to control blooms, which included hypolimnetic aeration, alum surface application, alum injection, inflow water volume reduction and inflow alum treatment. In addition, two water level drawdowns dropped the water level 3 meters in 2006 for 138 days and 7 meters in 2010 
for 264 days. Although the purpose of these drawdowns was lake and facility maintenance, the consequence of water level fluctuations can be important in affecting the lake ecosystem (Bakker \& Hilt, 2016; Pan et al., 2018). Table 2 includes more detailed information about the in-lake management practices implemented in Oswego Lake between 2001 and 2013. In addition, current watershed management in place in order to reduce nutrient loading to the lake, besides the Tualatin River inflow control, includes several storm water best management practices (e.g., wet retention ponds, dry detention ponds, swales, infiltration rain gardens, underground injection control systems, and lined planter rain gardens), and bank stabilization through promotion of native vegetation and removal of invasive species along stream banks.

\subsection{Sampling and measurement}

Physical, chemical and biological parameters were measured weekly or biweekly at eight sampling sites in Oswego Lake for long-term water quality monitoring. The sampling sites, corresponding with the various aspects of lake morphology, include one site at each of two shallow basins, the outlet and two canals, and three sites at the main lake basin. Two sampling sites between July and September from 2001 to 2013 were chosen for this study, including the main lake center sampling site (Appendix A), where maximum depth is more than 15 meters and captures summer thermal stratification, and the Oswego Canal sampling site, which reflects the Tualatin River inflows (Figure 3).

At the lake center, water temperature, $p \mathrm{H}$, percent saturation of dissolved oxygen, and specific conductivity were recorded at every meter from $0.38 \mathrm{~m}$ to $15 \mathrm{~m}$ below the 
surface using YSI 6600 multiparameter water quality sonde. The values of epilimnetic water quality parameters were generated by averaging the YSI sonde measurements at depths between 1 and 5 meters. Turbidity, using grab sample at elbow depth, was measured using the Hatch 2100Q Turbidimeter.

Water samples for total suspended solids (TSS), nutrients, chlorophyll $a$ and phytoplankton were collected using Kemmerer sampler from specific depths. The epilimnion samples were the equal-volume composite of water samples taken at discrete depths of 1, 2, 3, 4, and 5 meters. The hypolimnion samples were the equal-volume composite of water samples taken at discrete depths of 10,12, and 14 meters. The canal samples were collected by placing Kemmerer sampler in the middle of the water column usually about 1 meter deep.

Epilimnetic TSS samples were stored in capped bottles, kept in a cooler in the field and in the refrigerator in the Lake Oswego Corporation (LOC) laboratory until the time of analysis. TSS was measured by filtering 1-liter well-mixed water sample through a weighted standard glass-fiber filter (Whatman 934-AH filter, $47 \mathrm{~mm}$ ), and by measuring the weight of the residue retained on the filter that was dried to a constant weight at $103{ }^{\circ} \mathrm{C}$ in the oven (APHA, 2012) (Appendix B1). The difference in weight of the filter represents the TSS.

Nutrients were sampled for total phosphorus (TP), soluble reactive phosphorus (SRP), and total nitrogen (TN). Samples were stored in new bottles, kept in a dark cooler in the field, and shipped overnight with ice packs to Aquatic Research, Inc. (ARI) in Seattle, 
Washington. ARI received the samples the next day and analyzed the samples based on the ascorbic acid method to determine TP and SRP (detection limits of $0.002 \mathrm{mg} / \mathrm{L}$ for TP and $0.001 \mathrm{mg} / \mathrm{L}$ for SRP), and the persulfate digestion method to determine $\mathrm{TN}$ (detection limit of $0.100 \mathrm{mg} / \mathrm{L}$ ) (APHA, 2012; Godomski, 2013).

Chlorophyll $a$ samples were obtained by filtering $300-500 \mathrm{~mL}$ of sampling water with the addition of $1 \mathrm{~mL}$ of saturated magnesium carbonate $\left(\mathrm{MgCO}_{3}\right)$ solution through one piece of $0.45 \mu \mathrm{m}$ glass fiber filter. The filter was folded, stored in a capped centrifuge tube, kept in a dark cooler in the field, and stored in a dark freezer in the LOC laboratory until the time of analysis. Chlorophyll $a$ measurement was processed in subdued light to avoid degradation. Chlorophyll $a$ was extracted by centrifuging the sample with the addition of $90 \%$ aqueous acetone. Then the optical densities of the $90 \%$ acetone extracts and the acidified extracts with addition of $0.1 \mathrm{~mL} 0.1 N$ hydrochloric acid (HCL) were determined with a spectrophotometer (APHA, 2012) (Appendix B2). The concentration of chlorophyll $a$ was calculated as follows:

$$
\text { Chlorophyll a }(u g / L)=\frac{26.7 \times[(664 b-750 b)-(665 a-750 a)] \times 19.5}{V \div 1000}
$$

Where:

$$
\begin{aligned}
& 26.7=\text { absorbance correction constant } \\
& 19.5=\text { volume of extract }(\mathrm{mL}) \\
& \mathrm{V}=\text { volume of sample }(\mathrm{mL})
\end{aligned}
$$

$664 b, 750 b, 665 a, 750 a=$ optical densities of $90 \%$ acetone extracts before and after acidification 
Phytoplankton samples (500 mL each) were stored in bottles, preserved with $3 \mathrm{~mL}$ Lugol's solution per sample, kept in a dark cooler in the field, and shipped overnight with ice packs to WATER Environmental Services, Inc. (WES) in Seattle, Washington. WES determined phytoplankton cell volume dimensions and identifications using a $0.1 \mathrm{~mL}$ Palmer-Maloney nanoplankton chamber with a calibrated whipple disc under Leitz compound microscope at $400 \mathrm{X}$ high magnification or at $1000 \mathrm{X}$ magnification with oil immersion. Geometric cell dimensions of at least 10 organisms of each phytoplankton were computed to obtain average cell volume per taxon and used to calculate cell volumes for the lake sample. Phytoplankton identification was made to species level where possible. Species identifications were conducted primarily according to Prescott (1975, 1980), Patrick and Reimer (1966, 1975), Smith (1950), Wehr and Sheath (2003), and recent journal article sources (M. Gibbons, 2013) (Appendix B3). 


\subsection{Data description}

\subsubsection{Phytoplankton data}

The phytoplankton taxon biovolumes were converted to the percentage of total biovolume of each sample in order to characterize phytoplankton assemblages. The division dataset was created based on the untrimmed phytoplankton species dataset that included 129 taxa (Appendix D). The species dataset was created by removing the rare species that occurred $<3$ samples among all samples to reduce noise for further multivariate analysis (Poos \& Jackson, 2012), which resulted in a total of 50 taxa (Appendix D).

Since cyanobacteria, diatoms and chlorophytes, accounting for more than $80 \%$ of total phytoplankton biovolume, dominated the phytoplankton assemblages over 13 years, the data analysis of divisions was focused on these three largest divisions (Appendix E). Further, cyanobacteria were divided into two groups, nitrogen-fixers and non-nitrogenfixers, because the occurrence of nitrogen-fixing cyanobacteria may suggest nitrogen limitation in environmental conditions (Schindler, 1977).

\subsubsection{Environmental data}

In addition to water quality, climate and weather conditions were used to identify the environmental impact on the changes of phytoplankton assemblages. Large-scale climatic effects were characterized by using the multivariate ENSO index (MEI) obtained 
from the NOAA (https://www.esrl.noaa.gov/psd/enso/mei/table.html) and the Pacific Decadal Oscillation (PDO) index obtained from the Joint Institute for the Study of the atmosphere and Oceans, University of Washington, Washington (http://research.jisao.washington.edu/pdo/PDO.latest). The MEI ranks (obtained from https://www.esrl.noaa.gov/psd/enso/mei/rank.html, updated on 6 April 2018) were used because the MEI ranks are useful to interpret ENSO strengths that are defined by a 1-69 scale. The lowest number (1) indicates the strongest La Niña case while the highest number (69) indicates the strongest El Niño case. MEI ranks from 1-14-21 denote strong-moderate-weak La Niña conditions, while 49-56-69 denote weak-moderate-strong El Niño conditions, respectively. The local weather conditions were characterized by monthly means of air temperature, wind speed, wind direction and solar radiation on daily data between 5am and 9pm (summer day time), and monthly sum of rainfall on 24hour daily data. The monthly averages of wind speed and wind direction were calculated using R function 'timeAverage' in package 'openair' to treat wind direction correctly through vector-averaging (Carslaw \& Ropkins, 2018; Grange, 2014). The weather data were obtained from the weather station on the roof of the LOC's office next to the outlet of the lake (Figure 3). 


\subsection{Data analysis}

To describe the long-term changes in phytoplankton assemblages, a combination of hierarchical agglomerative cluster method with Ward's minimum variance method (Ward Jr., 1963) was used to identify relatively homogeneous groups of phytoplankton assemblages using the Bray-Curtis dissimilarity index (Bray \& Curtis, 1957). Analysis of Similarity (ANOSIM) was used to test statistical significance of the differences among the cluster groups (Clarke, 1993). Dominant taxa and indicator taxa were further used to characterize the cluster groups of similar phytoplankton assemblages. Dominant taxa were defined as most abundant taxa that account for more than $50 \%$ of total phytoplankton biovolume within the group. Indicator taxa were defined as the taxa, belonging to cyanobacteria, diatoms and chlorophytes, with an indicator species index $>0.5(p<0.05)$ based on Dufrene-Legendre indicator species analysis (Dufrene \& Legendre, 1997). $P$ values of indicator species for all taxa were determined using Monte Carlo permutation tests (1000 times).

Further, nonmetric multidimensional scaling (NMDS) based on Bray-Curtis dissimilarity matrix was used to visualize the changes among the groups of phytoplankton assemblages over time. NMDS is a multivariate ordination technique commonly used in ecological community analysis (Clarke, 1993). NMDS projects each sample into a species-defined ordination space with two or more dimensions based on their ranked dissimilarity. The goodness-of-fit for the NMDS projections was measured as a stress value which quantifies the deviation from a monotonic relationship between the distance among samples in the original Bray-Curtis dissimilarity matrix and the distance among 
samples in the ordination plot. The NMDS was run 20 times each with a random starting configuration. The final NMDS dimension was selected based on the lowest stress value among the best solutions.

The changes of phytoplankton assemblages were expected to associate with environmental factors. In order to assess this relationship, the environmental variables were related to the NMDS ordination space defined by the species data using "envfit" function in R (Oksanen et al., 2013). The importance of each environmental variable was assessed using a squared correlation coefficient $\left(\mathrm{r}^{2}\right)$. Furthermore, the lake management practices were related to the cluster groups of phytoplankton assemblages in a timeline manner for assessing the management effects on the dynamics of phytoplankton communities.

Data analysis was performed using R (R Development Core Team, 2014). Specifically, the packages 'vegan' and 'MASS' were used for the cluster and NMDS analysis, the package 'labdsv' for the indicator species analysis, and the package 'timevis' for the time relationship between lake management practices and the cluster groups of phytoplankton assemblages. 


\section{Results}

\subsection{Changes of environmental conditions over 13 years}

During the study period, water in the lake epilimnion in general had moderate nutrients (mean $\mathrm{TP}=39 \mu \mathrm{g} \mathrm{L}^{-1}$; mean SRP $=3 \mu \mathrm{g} \mathrm{L}^{-1}$; mean $\mathrm{TN}=460 \mu \mathrm{g} \mathrm{L}^{-1}$ ), low specific conductivity $\left(\right.$ mean $\left.=161 \mu \mathrm{S} \mathrm{cm}^{-1}\right)$, alkaline $p \mathrm{H}($ mean $=8.5)$ and moderate primary productivity (mean chlorophyll $a=16 \mu \mathrm{g} \mathrm{L}^{-1}$ ) (Figure 4 A \& D).

Concentrations of nutrients changed over 13 years. The greatest changes occurred in epilimnetic TP and SRP in 2005 when the alum surface treatment was applied (Figure 4A). Mean epilimnetic TP declined from $72 \mu \mathrm{g} \mathrm{L}^{-1}$ (2001-2004) to $25 \mu \mathrm{g} \mathrm{L}^{-1}$ (20052013), a $66 \%$ reduction, while mean epilimnetic SRP declined from $8 \mu \mathrm{g} \mathrm{L}^{-1}$ to $0.6 \mu \mathrm{g} \mathrm{\textrm {L } ^ { - }}$ 1, a 93\% reduction. Mean epilimnetic TN gradually declined from $585 \mu \mathrm{g} \mathrm{L}^{-1}$ to $403 \mu \mathrm{g}$ $\mathrm{L}^{-1}$, a $31 \%$ reduction. In contrast, mean epilimnetic TN:TP ratio increased from 9 to 18 . Meanwhile, the most visible changes of hypolimnetic nutrients occurred in 2001 when hypolimnetic aeration began (Figure 4B). Mean hypolimnetic TP declined from $292 \mu \mathrm{g}$ $\mathrm{L}^{-1}$ (2001) to $69 \mu \mathrm{g} \mathrm{L}^{-1}$ (2002-2013), a 77\% reduction, with mean hypolimnetic SRP decreasing from $62 \mu \mathrm{g} \mathrm{L}^{-1}$ to $14 \mu \mathrm{g} \mathrm{L}^{-1}$ (77\%) and mean hypolimnetic TN decreasing from $2,083 \mu \mathrm{g} \mathrm{L}^{-1}$ to $880 \mu \mathrm{g} \mathrm{L}^{-1}(58 \%)$. In addition, concentrations of nutrients in inflow water from the Tualatin River were high during the study period (Figure 4C). Over 13 years, mean inflow TP was $112 \mu \mathrm{g} \mathrm{L}^{-1}$; mean inflow SRP was $45 \mu \mathrm{g} \mathrm{L}^{-1}$; and mean inflow TN was 3,667 $\mu \mathrm{g} \mathrm{L}^{-1}$. Both lowest inflow TP $\left(\right.$ mean $\left.=50 \mu \mathrm{g} \mathrm{L}^{-1}\right)$ and SRP $($ mean $=9 \mu \mathrm{g}$ $\mathrm{L}^{-1}$ ) occurred in 2012, the first year when inflow was treated with alum. 
Several other epilimnetic water quality variables, such as $p \mathrm{H}$, turbidity and total suspended solids (TSS), varied in a similar pattern, showing an increasing trend in higher values between 2001 and 2004 and then dropping to relatively lower values between 2005 and 2013 (Figure 4D). Mean $p \mathrm{H}$ ranged from 9.4 (2001-2004) to 8.1 (2005-2013), with mean turbidity ranging from $10 \mathrm{NTU}$ to $3 \mathrm{NTU}$ and mean TSS ranging from $10 \mathrm{mg}$ $\mathrm{L}^{-1}$ to $4 \mathrm{mg} \mathrm{L}^{-1}$. Mean chlorophyll $a$ was higher between 2001 and 2006 except 2002 and lower between 2007 and 2013 (2001 and 2003-2006: $25 \mu \mathrm{g} \mathrm{L}^{-1}$; 2002: $12 \mu \mathrm{g} \mathrm{L}^{-1}$; 20072013: $11 \mu \mathrm{g} \mathrm{L}^{-1}$ ). Specific conductivity, $p \mathrm{H}$, turbidity and TSS strongly correlated to chlorophyll $a$ (Pearson correlation coefficient $r=0.60, r=0.54, r=0.57, r=0.44$, respectively, $p<0.01, \mathrm{n}=38$ ). Epilimnetic dissolved oxygen was saturated (mean $=$ 117\%). Epilimnetic water temperature varied between $18.1^{\circ} \mathrm{C}$ and $24.3{ }^{\circ} \mathrm{C}$ with an average of $22.0^{\circ} \mathrm{C}$.

Climate and meteorological conditions were moderate during the study period (Figure 4E). Annual means of MEI ranks between July and September from 2001 to 2013 indicated moderate El Niño in 4 years (2002, 2006, 2009 and 2012, ranks from 50 to 56) and moderate to strong La Niña (moderate: 2007 and 2011, ranks=17; strong: 2010, rank=6), with weak ENSO strength (ranks from 22 to 48) in other years. Annual means of PDO indices between July and September from 2001 to 2013 indicated a cold phase in 2001 followed by a warm phase about 4 years (2002-2005). The PDO phase was then neutral until 2007, following a cold phase from 2008 to 2013. Summer air temperatures were moderate, ranging from 18.0 to $21.4^{\circ} \mathrm{C}$ with an average of $20.1{ }^{\circ} \mathrm{C}$. Summer wind speed ranged from 0.04 to $0.38 \mathrm{~m} \mathrm{~s}^{-1}$ with an average of $0.18 \mathrm{~m} \mathrm{~s}^{-1}$, indicating calm to light air conditions. The prevailing wind directions were west-northwest and east during 
the study period, accounting for $17.4 \%$ and $15.8 \%$ of all wind directions, respectively (Appendix C). Two summers in 2004 (mean rainfall $=92 \mathrm{~mm}$ ) and $2013(72 \mathrm{~mm})$ were wetter than on average of other years $(15 \mathrm{~mm})$. Summer solar radiation ranged from 263 $\mathrm{W} \mathrm{m} \mathrm{m}^{-2}$ to $356 \mathrm{~W} \mathrm{~m}^{-2}$ with an average of $307 \mathrm{~W} \mathrm{~m}^{-2}$.

4.2 Changes of phytoplankton assemblages in relation to environmental conditions

Between July and September from 2001 to 2013, a total of 129 phytoplankton taxa belonging to eight divisions were identified, including 45 chlorophytes, 31 cyanobacteria, 25 diatoms, and 28 taxa belonging to the other five divisions (Appendix D). Phytoplankton assemblages were numerically dominated by cyanobacteria (mean relative abundance $=45 \%)$, followed by diatoms $(23 \%)$ and chlorophytes $(15 \%)$ (Appendix E).

Summer phytoplankton assemblages changed year-to-year over 13 years (Figure 5 and Figure 7). Overall, the relative abundance of cyanobacteria biovolume decreased $\left(\mathrm{R}^{2}=0.5, p<0.001\right)$ while that of diatom biovolume increased $\left(\mathrm{R}^{2}=0.5, p<0.001\right)$. Between 2001 and 2007, summer phytoplankton communities were dominated by cyanobacteria (mean relative abundance $=66 \%$ ), most comprised of non-nitrogen fixers, Lyngbya sp. (now known as Limnoraphis) and Microcystis sp.. Between 2008 and 2012, relative abundances of cyanobacteria were much lower $($ mean $=17 \%)$. In 2013, cyanobacteria was again dominant (49\%). Nitrogen fixers, Aphanizomenon flos- aquae, Anabaena sp.iroides and Anabaena planctonica, were most abundant cyanobacteria from 2008 to 2013. Diatoms increased from less than $10 \%$ to more than $30 \%$ over the study period, primarily comprised of Melosira sp. and Fragilaria sp.. In addition, two noticeable 
changes occurred in 2002 and 2006, the second years of the operations of 2001 hypolimnetic aeration and 2005 alum surface application. Relative abundance of cyanobacteria dropped $40 \%$ in both 2002 and 2006 compared to the previous years. Chlorophyte (41\%) was high in 2002, while diatoms (35\%) was high in 2006.

The cluster analysis identified 4 groups based on phytoplankton assemblages between July and September from 2001 to 2013 (Table 3, Figure 6, Figure 7A-D and Appendix F), and the groups were significantly different $(p=0.001)$ among each other based on ANOSIM. Group 1 (G1) was dominated by cyanobacteria that accounted for, on average, $81 \%$ of the total phytoplankton biovolume, which was mainly comprised of nonnitrogen fixers (67\%). Lyngbya sp., a filamentous non-nitrogen fixing cyanobacteria, was both the dominant species and the indicator species of G1. Group 2 (G2) was dominated by cyanobacteria (60\%) and chlorophytes (24\%). The dominant species and indicator species in this group were Microcystis sp. and Closteriopsis longissimi that were both common species found in eutrophic freshwaters. Group 3 (G3) had the highest relative abundance of diatoms (35\%) that was more abundant than cyanobacteria (30\%). G3 was comprised of common summer eutrophic assemblages, including non-motile diatoms (Melosira sp. and Fragilaria sp.), motile dinoflagellates (Ceratium hirundinella), nitrogen fixing cyanobacteria (Aphanizomenon flos-aquae and Anabaena sp.), and chlorophyte (Pandorina sp.). Group 4 (G4) was dominated by chlorophytes (38\%) and diatoms $(30 \%)$, while cyanobacteria were least abundant in this group. The dominant species and the indicator species of G4 belonged to cosmopolitan taxa found in various water trophic conditions, including oligotrophic to mesotrophic Oocystis sp. and 
eutrophic Coelastrum sp.. Regarding species diversity, G3 was most diverse (Shannon's diversity index $=2.9)$, followed by G4 (2.4), G2 (2.1) and G1 (1.9).

The NMDS plots revealed that phytoplankton assemblages shifted from cyanobacteria dominance to diatom and chlorophyte dominance over 13 years along NMDS axis I (Figure 7E-F). The NMDS axis I primarily reflected the gradients of nutrients (e.g., epilimnetic and hypolimnetic TP and TN, and inflow SRP) (Table 4 and Figure 7A-D). This change corresponded to the four groups identified by the cluster analysis. The NMDS axis I separated the cyanobacteria dominated G1 and G2 with nutrient-rich conditions from the diatom and chlorophyte dominated G3 and G4 with lower nutrient concentrations. Specifically, hypolimnetic nutrients were associated with G1, although only hypolimnetic TP and TN was significant vectors, while inflow SRP was significantly associated with G2. Other environmental variables that significantly correlated with the NMDS space defined by phytoplankton assemblages included $p \mathrm{H}$, dissolved oxygen and chlorophyll $a$, indicating high primary production (G1), as well as specific conductivity, turbidity and TSS, indicating turbid water condition (G2), and NP ratio (G4). The PDO index was statistically significant associated with the NMDS space and positively associated with G2. Climatic MEI, air temperature, rainfall, wind speed, wind direction and solar radiation did not show significant association with the NMDS space (Table 4). 
4.3 Changes of phytoplankton assemblages in relation to lake management practices

The changes of phytoplankton assemblage cluster groups were well associated with lake management practices in temporal terms (Figure 8). G1 dominated by cyanobacteria was associated with the period before the major management practices (hypolimnetic aeration in August 2001 and alum injection in March 2008). G2 dominated by cyanobacteria and chlorophytes occurred between one year after hypolimnetic aeration and one year before inflow reduction (June 2005) and alum surface application (August 2005). G3 dominated by diatoms and cyanobacteria occurred after alum surface application. G4 dominated by chlorophytes and diatoms occurred in 2009 (the year after alum injection), 2011 (the year after long period of drawdown) and 2013 (the year after inflow alum treatment). 


\section{Discussion}

The phytoplankton communities of Oswego Lake have experienced profound changes in the 13-year study period. The summer phytoplankton assemblages have shifted from cyanobacteria dominance to diatom and chlorophyte dominance (Figure 5 and Figure 8). The changes of summer phytoplankton assemblages were significantly correlated with the changes of physical and chemical water conditions and the large climatic pattern PDO (Figure 7) and strongly associated with lake management practices (hypolimnetic aeration and alum application) (Figure 8).

The results illustrate that alum treatment to Oswego Lake was the major contribution to a substantial reduction of phosphorus in the water column and improvement of water quality overall (Figure 4 and Appendix G). The concentration of epilimnetic TP and SRP declined by $66 \%$ and $93 \%$, respectively, compared to the period prior to alum treatment (Figure 4A). Meanwhile, the concentration of epilimnetic chlorophyll $a$ and turbidity decreased by $48 \%$ and $69 \%$, respectively (Figure 4D).

The results were comparable to the other cases of alum applications to lakes where alum resulted in reduction of in-lake total phosphorus and chlorophyll $a$ concentrations and improvement of water clarity (Huser, Egemose, et al., 2016; Welch \& Cooke, 1999). For example, Mirror and Shadow lakes, WI, were both within residential watersheds. The lakes are eutrophic due to storm sewer loading and internal loading. Alum additions successfully reduced mean TP from 93 to $20 \mu \mathrm{g} \mathrm{L}^{-1}$ (78\% reduction) in Mirror Lake and from 55 to $23 \mu \mathrm{g} \mathrm{L}^{-1}$ (58\% reduction) in Shadow Lake (Welch \& Cooke, 1999). 
Similarly, in Dollar Lake, OH, a small urban lake, alum lowered surface TP by $65 \%$ from the pretreatment concentration of $82 \mu \mathrm{g} \mathrm{L}^{-1}$ and chlorophyll $a$ by $61 \%$ from $41 \mu \mathrm{g} \mathrm{L}^{-1}$ for 7 years (Welch and Cooke, 1999). Huser, Egemose et al.'s (2016) study on the shortterm effects of alum on 83 urban lakes of varying size, morphology and hydrology also found that alum reduced epilimnetic TP from 101 to $36 \mu \mathrm{g} \mathrm{L}^{-1}$ (64\% reduction) and chlorophyll $a$ from 43 to $16 \mu \mathrm{g} \mathrm{L}^{-1}$ (63\% reduction), and increased Secchi depth from 1.6 to $2.4 \mathrm{~m}(50 \%$ increase $)$.

Few studies report the change of SRP but only TP when evaluating alum effectiveness on nutrient and cyanobacteria bloom control, probably because TP is relatively easy to measure (Huser, Futter, et al., 2016), although bioavailable forms of P, such as SRP, are more important than TP in understanding water quality and cyanobacteria blooms (Hatch, Reuter, \& Goldman, 1999). In Oswego Lake, the substantial decline of SRP by 93\% between pre- and post-alum treatment may be a strong evidence for successful reduction of $\mathrm{P}$ by alum treatment (Figure 4A and Appendix G).

In addition, previous studies have found that alum effectiveness lasted for about 13 to 15 years on average but declined over time due to bioturbation, sediment settling processes, and burial by new sediments (Huser, Futter, et al., 2016; Welch \& Cooke, 1999). The concentrations of TP and SRP in Oswego Lake were retained well between 2005 and 2013 at concentrations after the initial alum treatment in 2005, probably due to the annual alum treatments, including surface application, injection and inflow alum addition, and the effect of sediment oxidation by hypolimnetic aeration (B. C. Moore et al., 2012). 
While in-lake nutrient concentrations were substantially reduced after the alum application and hypolimnetic aeration, a shift from the phytoplankton communities dominated by cyanobacteria to diatoms and chlorophytes has been observed (Figure 5 and Figure 8). Although there is no single factor that drives phytoplankton community dynamics; in reality, it is due to the complex combination and interactions of physical, chemical, and biological phenomena, such as light, temperature, nutrients and food-web structure (Kosten et al., 2012). However, it has been widely accepted that phosphorus is typically the limiting nutrient in lakes and has strong correlation with phytoplankton production (Carpenter, 2008; McCauley et al., 1989; Prairie, Duarte, \& Kalff, 1989; Schindler, 2012; Schindler et al., 2008); therefore, phosphorus is commonly used as a primary trophic indicator (Carlson, 1977). Eutrophic lakes with internal phosphorus loading during vertical thermal stratification are particularly favorable for the massive development of cyanobacteria because cyanobacteria are able to regulate their buoyancy and access nutrient-rich hypolimnetic water (Carey et al., 2012).

Many lake restoration programs focused on reduction of phosphorus have proved to be effective in reducing cyanobacteria blooms (Huser, Futter, et al., 2016; Zamparas \& Zacharias, 2014). For example, Newman Lake, WA, is a dimictic lake and has stable thermal stratification between May and September. Cyanobacteria blooms in Newman Lake occurred annually in the 1970s and 1980s primarily due to summer hypolimnetic oxygen depletion and internal phosphorus loading (B. C. Moore et al., 2009). Cyanobacteria had a peak in 1989 , accounting for $>90 \%$ of total phytoplankton biovolume (B. C. Moore \& Christensen, 2009). Since 1989, a serial management practices implemented in Newman Lake for control of in-lake phosphorus and 
cyanobacteria blooms included whole-lake alum treatment, hypolimnetic oxygenation and microfloc alum injection. Cumulative management efforts have successfully reduced average summer TP from pre-restoration $55 \mu \mathrm{g} \mathrm{L}^{-1}$ to an average of $21 \mu \mathrm{g} \mathrm{L}-1$ over 7 years. Cyanobacteria blooms were no longer evident after the first whole-lake alum treatment, and cyanobacteria comprise $<8 \%$ of total phytoplankton biomass, while diatoms comprise between $50 \%$ and $75 \%$ and chlorophytes comprise $<15 \%$ of total phytoplankton biomass (B. C. Moore et al., 2012, 2009). Species shifts also occurred. Almost exclusive Microcystis sp. decreased after the first alum treatment with increasing Anabaena flos-aquae in the cyanobacteria assemblage (B. C. Moore et al., 2009). Later, Melosira sp. became the most abundant phytoplankton during aeration (Thomas, Funk, Moore, \& Budd, 1994). This shift in phytoplankton assemblages from cyanobacteria dominance to diatom and chlorophyte dominance was most likely a response to lower phosphorus availability (B. C. Moore \& Christensen, 2009).

The observations of changes of nutrients and phytoplankton communities after alum addition and hypolimnetic aeration in Oswego Lake are very similar to the findings in Newman Lake. Previous lake analysis on Oswego Lake identified that internal loading was one of the most significant sources of phosphorus in the lake (H. Gibbons \& Welch, 2004). Therefore, hypolimnetic aeration since 2001 and alum application since 2005 have been implemented in Oswego Lake to reduce internal P loading in control of cyanobacteria blooms. Since 2005 after alum treatment to Oswego Lake, coupled with hypolimnetic aeration, summer phytoplankton assemblages showed a $62 \%$ reduction of cyanobacteria biovolume (Figure 5), and cyanobacteria dominated phytoplankton communities gradually shifted to diatom and chlorophyte dominance (Figures 7 and 
Figure 8). Based on the concept of community ecology, the succession of dominant species is partly the consequence of changes to the environmental conditions (Reynolds, 2006). Compared to the "pre-shift" years of 2001 to 2004, the most remarkable changes in nutrient levels have occurred since 2005 , which may be the most probable explanation for the presence of the diatom dominant phytoplankton communities (Group 3). Furthermore, in Oswego Lake, the dominance of Melosira occurred in summer stratification periods, which is very likely a direct result of hypolimnetic aeration. Melosira is not capable of independently staying within the photic zone, due to its heavy silicon body, without upwelling water current during summer stratification. It is apparent that the hypolimnetic aeration in Oswego Lake circulated lake water and generated vertical mixing of the water sufficient to resuspend Melosira in the photic zone for growth. Lund (1971) observed a significant increase in summer Melosira population during the artificial destratification of a small lake in the English Lake District. Similarly, Thomas et al. (1994) reported that Melosira particularly adapted to hypolimnetic aeration that induced a turbulent environment and became the most abundant phytoplankton during summer aeration in Newman Lake. Therefore, the hypolimnetic aeration in Oswego Lake apparently played an important role in establishing a dominance of Melosira in summer phytoplankton communities. Results have shown, however, that hypolimnetic aeration alone prior to alum treatment did not significantly lower nutrient concentrations (Figure 4A), and that the major shift of dominant species from cyanobacteria to diatoms and chlorophytes occurred after the alum treatment (Figure 5 and Figure 8), which suggests that hypolimnetic aeration alone was not sufficient, but the synergistic effect of hypolimnetic aeration and alum treatment is most likely decisive. Hypolimnetic aeration, as a common management technique, has 
been reported to be successful in reducing internal phosphorus loading from the anoxic lake sediments, thus controlling cyanobacteria (Beutel \& Horne, 1999; Cooke et al., 2005). In Oswego Lake, the hypolimnetic nutrients (TP, SRP and TN) dropped steeply in 2002, the second year of the operation of hypolimnetic aeration (Figure 4B). However, between 2001 and 2004, the epilimnetic nutrients were still high (Figure 4A). And cyanobacteria were most dominant, accounting for $>80 \%$ of total phytoplankton biovolume, with the exception of 2002 when cyanobacteria comprised $51 \%$ and chlorophytes comprised of $41 \%$ (Figure 5). Moreover, Microcystis was most dominant in 2002 and a Microcystis bloom occurred in 2004. These observations may reflect high nutrient inputs from external sources (Oberholster et al., 2006).

Oswego Lake, within an urban watershed, has a high watershed/drainage area to lake area ratio of more than 10:1, indicating a strong influence of watershed to the lake (Schueler \& Simpson, 2001). The drainage pipe network contains 70 stormwater outfalls surrounding the lake, and $40 \%$ of storm water from the City of Lake Oswego drains into the lake directly through the pipes (Rubenson, 2016). In urbanized watersheds, the problem of stormwater runoff from impervious surfaces, such as roofs, roads and driveways, has been widely recognized, which is that piped runoff rapidly transfers nutrients, sediments and other pollutants throughout the urban watershed to the receiving waters, resulting in degradation of water quality in receiving waters (Roy et al., 2008). In the watershed of Oswego Lake, imperviousness has been found to be the primary landscape characteristic influencing phosphorous loading, therefore, stormwater runoff is an important phosphorus source to the lake (Rubenson, 2016). 
In addition, three stream inflows contribute significant phosphorus to the lake. Rubenson (2016) found that the concentrations of total phosphorus and total suspended solids were similar in piped drainages and streams, but due to higher flows in streams, streams contribute a higher load of phosphorus to the lake. Annually, approximate 376 kilograms of phosphorus loads into the lake from the Tualatin River and approximate 1023 kilograms from Springbrook Creek (ODEQ, 2001). Eroded riparian and soil along the riverbank input significant phosphorus into Lost Dog Creek that further transports phosphorus to the lake (B. S. Johnson, 2009). Soil erosion is a major source of phosphorus in the watersheds of northwestern Oregon that is between an uplifted subduction complex of the Coast Range and active andesitic volcanoes of the Cascade Range (Abrams \& Jarrell, 1995; Retallack \& Burns, 2016). Much of the watersheds in northwestern Oregon are underlain by volcaniclastic marine sandstones and siltstones and large areas of the basin floor are covered by nutrient-rich silts from the Missoula Floods dating back to the last ice age (Foster, 2009; Retallack \& Burns, 2016). These watershed geological characteristics dictate that the Oswego Lake watershed is a native phosphorus source to the lake. As watershed nutrient loading is still high, hypolimnetic aeration targets internal loading of phosphorus from sediments may not be effective in reduction of phosphorus in the lake (Liboriussen et al., 2009).

It is apparent that reduction of phosphorus in the primary stream tributaries to the lake is necessary to further reduce in-lake phosphorus. The Tualatin River is the primary water supply to the lake during summer in order to maintain water level in the lake for summer water uses, such as recreation and irrigation. During the study period, phosphorus concentrations of inflow water from the Tualatin River were relatively high (mean TP 
$=112 \mu \mathrm{g} \mathrm{L}{ }^{-1}$, mean SRP $=45 \mu \mathrm{g} \mathrm{L}^{-1}$ ) (Figure 4C). Beginning in 2005, the annual inflow duration was reduced from 3-5 months (2001-2004) to 2-3 months (after 2005), for the purpose of reducing inflows; consequently, nutrient loading from the Tualatin River to the lake were reduced. Although the canal TP and SRP declined after inflow duration reduction in 2005 , inflow volume reduction was not as substantial as reduction of in-lake TP and SRP when the lake was treated with alum (Figure 4C). This result suggests that the significant reduction of in-lake phosphorus in 2005 was very likely due to the in-lake nutrient management practices (alum and hypolimnetic aeration).

Beginning in 2012, the inflow water was treated with alum before entering the lake. Inflow phosphorus steeply decreased immediately after the inflow alum treatment in 2012, and inflow SRP remained low in 2012 and 2013 (Figure 4C), which suggests that alum was effective in removing phosphorus from inflow to the lake. Meanwhile, the fact that chlorophyte and diatom dominated phytoplankton communities (Group 4) occurring in the following year of inflow alum treatment suggests that inflow alum may contribute to the change of phytoplankton communities. The effectiveness of inflow alum treatment in removal of phosphorus prior to discharge into the lake and in improvement of lake water quality was also found in other studies where the major tributary to the lake contributes inflow water carrying high phosphorus loading (Heinzmann \& Chorus, 1994; Pilgrim \& Brezonik, 2005). For example, in two urban eutrophic lakes in Minnesota, Tanners Lake and Fish Lake, the treatments to the inflow water with alum resulted in reduction of in-lake TP, accompanied by decreases in chlorophyll $a$ and improvement in Secchi disk depth (Pilgrim \& Brezonik, 2005). In addition, a significant correlation was found between inflow SRP and in-lake SRP in Oswego Lake (Pearson correlation 
coefficient $r=0.52, p<0.001, \mathrm{n}=38$ ), suggesting that reducing SRP in inflow water may result in reduction of SRP in the lake; thus, inflow alum treatment is necessary in nutrient management in Oswego Lake.

The management activities in Oswego Lake during the study period, besides hypolimnetic aeration and alum addition directly targeting water quality, included two water level drawdowns, which dropped the water level 3 meters in 2006 for 138 days and 7 meters in 2010 for 264 days. Although the purpose of two drawdowns were lake and facility maintenance, the consequence of water level drawdown can be important in affecting lake ecosystem (Bakker \& Hilt, 2016; Pan et al., 2018). For example, during drawdown, nutrients and plankton in the lake can be partly removed while the water body is flushed out. Drawdown, in some extend, can be seen as a "reset" and an important disturbance of the lake ecosystem. In Oswego Lake, no significant change in the phytoplankton community was observed after the first drawdown; however, in two years following the second drawdown, chlorophytes reached one of three high relative abundance values (Figure 5) and a more diversified assemblage of chlorophytes and diatoms presented, which indicated that duration and strength of drawdown may affect lake ecosystems. Group 4 probably was a result of the second drawdown because the phytoplankton species in Group 4 are regarded as R-strategist that can respond quickly and positively to environmental changes (Reynolds, 2006).

In this study, the Pacific Decadal Oscillation (PDO) index showed a statistically significant correlation with the summer phytoplankton communities that, however, were not significantly correlated with the multivariable ENSO index (MEI) in Oswego Lake 
(Figure 7D and Table 4). This result is comparable to a study in Lake Washington, which found that the impact of PDO on the spring plankton communities was stronger than ENSO (Winder \& Schindler, 2004). Winder and Schindler (2004) showed that vernal warming induced advanced stratification onset and phytoplankton spring bloom in Lake Washington by 20 days, which coincided with the warm phase of the PDO. Meanwhile, the delayed stratification termination was described by the regression model of air temperature and the PDO index. Thus, Winder and Schindler (2004) concluded that PDO is an important driver for physical processes in Lake Washington. However, in my study, PDO switched phases from warm to cool during 2005 and 2006, a period that coincided with the beginning of the lake's alum treatment in 2005 (Figure 8 and Appendix H). Although many studies have reported that changing climatic conditions can directly and indirectly affect phytoplankton species succession, structure and composition through altering lake's physical, chemical and biological conditions (i.e., water column thermal stratification, thermocline depth, nutrient availability, and zooplankton succession), as well as watershed hydrological conditions (i.e., basin streamflow) (Livingstone, 2003; Livingstone \& Dokuli, 2001; Magnuson et al., 1997; Shimoda et al., 2011; Winder \& Schindler, 2004), isolation of climate impacts is very difficult due to complex internal feedbacks to stressors and complicated confounding factors, such as eutrophication and acidification in lakes themselves (Adrian et al., 2009). Without further analysis of the correlation between PDO and a wide spectrum of lake parameters such as annual variabilities and stratification characteristics across a long period of time due to the PDO cycles of 20-30 years (Mantua \& Hare, 2002), any conclusions regarding significant PDO impacts on the changes in summer phytoplankton communities would be premature. 
In addition, correlations of weather conditions (air temperature, rainfall, wind speed, wind direction and solar radiation) and summer phytoplankton communities were insignificant during the study period in Oswego Lake (Figure 7H and Table 4). However, it is notable that the high production of cyanobacteria might be in response to high rainfalls and high water temperatures in 2004 and 2013, including a Microcystis bloom in 2004 (Appendix J). In the region of the Oswego Lake watershed, the summer is usually characterized as warm and dry. Warming favors blooms of harmful cyanobacteria and likely increases cyanobacteria dominance in phytoplankton communities (Paerl \& Huisman, 2008). Wetter summers than usual can increase external nutrient loading to the lake and thus increase cyanobacterial biomass (Reichwaldt \& Ghadouani, 2012), especially if the lake is in an urban setting with nutrient rich soil within the watershed. 


\section{Study limitation}

The influence of climate impacts on phytoplankton communities in this study was not conclusive. Firstly, the Pacific Decadal Oscillation (PDO) index showed a statistically significant correlation with the summer phytoplankton communities that, however, were not significantly correlated with the multivariable ENSO index (MEI) and weather conditions (air temperature, rainfall, wind speed, wind direction and solar radiation) in Oswego Lake. Meanwhile, PDO switched phases from warm to cool during 2005 and 2006, a period that coincided with the beginning of the lake's alum treatment in 2005. Without further analysis of the correlation between PDO and a wide spectrum of lake parameters such as annual variabilities and stratification characteristics across a long period of time due to the PDO cycles of 20-30 years (Mantua \& Hare, 2002), any conclusions regarding significant PDO impacts on the changes in summer phytoplankton communities would be premature. Secondly, the multivariable ENSO index (MEI) was found no significant correlation with the summer phytoplankton community variabilities in Oswego Lake. It should be noted that this study falls by chance between two extreme El Niño events (1997-1998 and 2015-2016) (Appendix I). Both events have been reported to have strong impacts on phytoplankton in freshwater and coastal waters (Cavole et al., 2016; McGowan et al., 2005). However, in this study from 2001 to 2013, the intensity of both El Niño and La Niña were mostly categorized as weak or moderate. This study found no significant relationship between MEI and the phytoplankton community dynamics, which was probably due to the low variability of ENSO as well. Therefore, I cannot conclude the changes of the phytoplankton communities were due to lake management alone, although that was a major finding of this study. 
In addition, this study did not investigate food web structure that directly regulate phytoplankton population (Shapiro et al., 1975). Research on food web networks in lake ecosystems should afford a deeper understanding of phytoplankton dynamics. 


\section{Conclusion and management implication}

This study investigated a long-term change of phytoplankton communities in an urban lake to better understand what factors most likely impacted such change. During the years 2001 to 2013, the summer phytoplankton communities of Oswego Lake shifted in dominance from cyanobacteria to diatoms and chlorophytes. This shift very likely resulted from the reduction of in-lake phosphorus due to alum treatments, coupled with hypolimnetic aeration, because a strong temporal relationship was found between these management practices and the changes of in-lake phosphorus and phytoplankton communities.

Alum treatment in Oswego Lake, as well as in other lake restoration projects, has been effective in reduction of in-lake phosphorus concentration and in control of cyanobacteria blooms (Cooke et al., 2005). Although assessment on management cost was not conducted in this study, other studies have documented that water treatment using chemicals, such as alum, can be very costly (EPA, 2015). Costs of alum application depend on dosage used, area treated, and equipment and labor costs. EPA (2015) reported that the costs associated with alum application could be more than $\$ 28$ million in capital and \$1.4 million in annual operation and maintenance for a dredging and alum treatment plan intended to last more than 50 years in Lake Lawrence $\left(1.3 \mathrm{~km}^{2}\right)$, Washington.

The results of this study implied that watershed external nutrient loading can be significant to Oswego Lake, which is consistent with Rubenson's (2016) study of the 
influence of stormwater drains and landscape characteristics on phosphorus loading in Oswego Lake. Urban watershed loads through stormwater runoff from impervious surfaces and soil erosion lead to increasing sedimentation of nutrients and organic materials in lakes and subsequently reinforcing internal cycling of nutrients, fueling cyanobacteria blooms (Søndergaard et al., 2003). Current watershed management is in place to reduce nutrient loading to the lake. In addition to Tualatin River inflow control, there has been implementation of several storm water best management practices (e.g., wet retention ponds, dry detention ponds, swales, infiltration rain gardens, underground injection control systems, and lined planter rain gardens), and bank stabilization through promotion of native vegetation and removal of invasive species along stream banks. The watershed is the ultimate source of nutrient input to lakes, so reduction in supply of nutrients from the lake watershed is a sustainable and cost-efficient approach for longterm efforts to protect water quality.

The influence of climate impacts on phytoplankton communities in this study was not conclusive. Firstly, the Pacific Decadal Oscillation (PDO) index showed a statistically significant correlation with the summer phytoplankton communities in Oswego Lake. However, PDO switched phases from warm to cool during 2005 and 2006, a period that coincided with the beginning of the lake's alum treatment in 2005 . Without further analysis of the correlation between PDO and a wide spectrum of lake parameters such as annual variabilities and stratification characteristics across a long period of time due to the PDO cycles of 20-30 years (Mantua \& Hare, 2002), any conclusions regarding significant PDO impacts on the changes in summer phytoplankton communities would be premature. Secondly, no significant correlation was found between the multivariable 
ENSO index (MEI) and the variability of the summer phytoplankton communities in Oswego Lake, probably due to the low variability of the climate factor during the study period. However, rising temperatures, increasing runoff of nutrients, and other climate change may favor cyanobacteria and accelerate deterioration of aquatic ecosystems; therefore, climate impacts should be carefully considered in ongoing analysis on both watershed and in-lake management.

The challenges of water quality management in Oswego Lake still exist, including dynamic lake system, expensive alum treatment and hypolimnetic aeration, significant nutrient input from watershed, and uncertain climate impacts on lake ecosystem. Adaptive management could be useful for facilitating decision making on lake management with an emphasis on reducing costs and uncertainties of the system over time in order to improve management. Adaptive management is a learning-based approach, integrating science and management, and incorporating what has been learned from past operations into ongoing management decision making. The modelling process plays an important role in adaptive management, as integrating existing scientific information, understanding of the system, and performance of management practices to frame predictions about impacts of management strategies for helping managers to achieve objectives. This study suggests that managers should consider utilizing a comprehensive water quality and hydrodynamic model that links management practices to watershed and lake ecological processes and climate variabilities, representing benefits and costs in terms of management inputs and outcomes, and allowing evaluation and prediction of management impacts. 
Tables 
Table 1: Morphometric characteristics of Oswego Lake.

\begin{tabular}{ll}
\hline Parameter & Values \\
\hline Surface area & $1.7 \mathrm{~km}^{2}$ \\
Maximum depth & $16.7 \mathrm{~m}$ \\
Mean depth & $7.9 \mathrm{~m}$ \\
Volume & $12.7 \times 10^{6} \mathrm{~m}^{3}$ \\
Maximum length & $5.1 \mathrm{~km}$ \\
Maximum width & $0.6 \mathrm{~km}$ \\
Shoreline length & $19.2 \mathrm{~km}$ \\
Residence time & $2 \mathrm{months}$ \\
Surface elevation & $30 \mathrm{~m}$ \\
Watershed area & $18.6 \mathrm{~km}^{2}$ \\
\hline
\end{tabular}


Table 2: Major management practices implemented in Oswego Lake between 2001 and 2013. (The information was provided by Mark Rosenkranz, the Water Resources Manager of Lake Oswego Corporation.)

\begin{tabular}{|c|c|c|c|c|}
\hline & Description & Objectives & Operation period & $\begin{array}{l}\text { Nutrient } \\
\text { response }\end{array}$ \\
\hline $\begin{array}{l}\text { Hypolimnetic } \\
\text { aeration }\end{array}$ & $\begin{array}{l}\text { Increase oxygen } \\
\text { levels near lake } \\
\text { bottom in order to } \\
\text { reduce P released } \\
\text { from sediments. } \\
\text { Hypolimnetic } \\
\text { aeration circulates } \\
\text { oxygenated water } \\
\text { from the bottom of } \\
\text { the thermocline to } \\
\text { the bottom of the } \\
\text { lake. This is } \\
\text { accomplished in } \\
\text { aeration towers that } \\
\text { use a bubble plume } \\
\text { to circulate low } \\
\text { oxygen water up near } \\
\text { the thermocline, thus } \\
\text { forcing higher } \\
\text { oxygen water down } \\
\text { near the sediment. } \\
\text { Hypolimnetic } \\
\text { aeration maintains } \\
\text { lake stratification. }\end{array}$ & $\begin{array}{l}\text { Providing more } \\
\text { oxygen at the } \\
\text { sediment } \\
\text { maintains the Fe- } \\
\text { P complex, } \\
\text { reducing P release } \\
\text { to the overlying } \\
\text { water and become } \\
\text { bioavailable for } \\
\text { algae growth. }\end{array}$ & $\begin{array}{l}\text { Since } 2001.8 \text {, } \\
\text { during thermal } \\
\text { stratification } \\
\text { period }\end{array}$ & P decreases \\
\hline Alum & $\begin{array}{l}\text { Add aluminum } \\
\text { sulfate to water to } \\
\text { form hypo-reactive } \\
\text { aluminum hydroxide } \\
\text { floc that adsorbs and } \\
\text { precipitates dissolved } \\
\text { phosphate to } \\
\text { sediments. }\end{array}$ & $\begin{array}{l}\text { Precipitate } \mathrm{P} \text { in } \\
\text { water column to } \\
\text { the sediment, } \\
\text { reducing } \\
\text { bioavailable P. }\end{array}$ & $\begin{array}{l}\text { Alum surface } \\
\text { application: } \\
\text { - In 2005.8: used } \\
\text { dry powdered } \\
\text { compound; since } \\
\text { 2006: used } \\
\text { liquid alum } \\
\text { - applied early } \\
\text { spring to late } \\
\text { summer yearly; } \\
\text { usually started } \\
\text { right after rain } \\
\text { season } \\
\text { Alum injection: } \\
\text { Since 2008, } \\
\text { usually applied in } \\
\text { March until late } \\
\text { summer }\end{array}$ & P decreases \\
\hline
\end{tabular}


Table 2: Continued

\begin{tabular}{|c|c|c|c|c|}
\hline & Description & Objectives & $\begin{array}{l}\text { Operation } \\
\text { period }\end{array}$ & Nutrient response \\
\hline Drawdown & $\begin{array}{l}\text { Discharge water } \\
\text { from the lake } \\
\text { through outlet gate } \\
\text { to the Willamette } \\
\text { River. }\end{array}$ & $\begin{array}{l}\text { The primary } \\
\text { purpose of } \\
\text { drawdown is for } \\
\text { seawall and dock } \\
\text { maintenance. } \\
\text { The 2010-2011 } \\
\text { drawdown was } \\
\text { required for a } \\
\text { sewer pipe } \\
\text { replacement; and } \\
30,000 \text { cubic yards } \\
\text { of sediment was } \\
\text { removed. }\end{array}$ & $\begin{array}{l}\text { 2006.11: lasted } \\
\text { for 138 days }(\approx 5 \\
\text { months), } \\
\text { drawdown } 3 \\
\text { meters. } \\
\text { 2010.9: lasted for } \\
\text { 264 days ( } \approx 9 \\
\text { months), } \\
\text { drawdown } 7 \\
\text { meters. }\end{array}$ & $\begin{array}{l}\text { Major disturbance } \\
\text { to the lake } \\
\text { ecosystem. } \\
\text { Potential effects of } \\
\text { drawdown: } \\
\text { - Erosion of } \\
\text { exposed } \\
\text { sediment } \\
\text { - Sediment } \\
\text { freezing } \\
\text { - Potential to } \\
\text { freeze aquatic } \\
\text { plants } \\
\text { - Potential high } \\
\text { turbidity during } \\
\text { rain events }\end{array}$ \\
\hline $\begin{array}{l}\text { Tualatin River } \\
\text { inflow control }\end{array}$ & $\begin{array}{l}\text { The primary water } \\
\text { inflow during } \\
\text { summer (June-Sept.) } \\
\text { is from the Tualatin } \\
\text { River. A headgate } \\
\text { on Oswego Canal } \\
\text { controls water flow } \\
\text { into Oswego Lake } \\
\text { from the Tualatin } \\
\text { River and timing of } \\
\text { water use depends } \\
\text { on spring rainfall. }\end{array}$ & $\begin{array}{l}\text { Maintain water } \\
\text { level in the lake for } \\
\text { the purpose of } \\
\text { summer recreation } \\
\text { and irrigation use. }\end{array}$ & $\begin{array}{l}\text { 2001-2004: } \\
\text { opened for 3-5 } \\
\text { months yearly; } \\
\text { Since 2005: } \\
\text { opened for 2-3 } \\
\text { months yearly; } \\
\text { * Since 2012.8, } \\
\text { inflow treated } \\
\text { with alum. }\end{array}$ & $\begin{array}{l}\text { Due to relative high } \\
\text { concentration of } \mathrm{N} \\
\text { and } \mathrm{P} \text { in the } \\
\text { Tualatin River, } \mathrm{N} \text { is } \\
\text { expected to } \\
\text { increase in the lake } \\
\text { during the time of } \\
\text { headgate opening. } \\
\text { Theoretically, } \\
\text { because of alum } \\
\text { treatment, } \mathrm{P} \text { is not } \\
\text { expected to be } \\
\text { high. However, in } \\
\text { practice, } \mathrm{P} \text { removal } \\
\text { is not complete so a } \\
\text { fair amount is } \\
\text { imported during } \\
\text { summer. }\end{array}$ \\
\hline
\end{tabular}


Table 3: Phytoplankton dominant taxa and indicator taxa of 4 groups based on the cluster analysis. The assemblage of species composes of more than $50 \%$ of total phytoplankton biovolume.

\begin{tabular}{|c|c|c|c|}
\hline Assemblage & $\begin{array}{l}\text { Taxonomic } \\
\text { group }\end{array}$ & $\begin{array}{l}\text { Relative } \\
\text { Abundance }\end{array}$ & $\begin{array}{l}\text { Indicator } \\
\text { value }\end{array}$ \\
\hline \multicolumn{4}{|l|}{ Group 1} \\
\hline Lyngbya sp. & non-N fixing Cyanobacteria & $52 \%$ & 0.8 \\
\hline Unicellular cyano & Cyanobacteria & & 0.5 \\
\hline \multicolumn{4}{|l|}{ Group 2} \\
\hline Microcystis sp. & non-N fixing Cyanobacteria & $31 \%$ & 0.7 \\
\hline Closteriopsis longissimi & Chlorophyte & $23 \%$ & 0.9 \\
\hline \multicolumn{4}{|l|}{ Group 3} \\
\hline Melosira sp. & Diatom & $25 \%$ & 0.7 \\
\hline Ceratium hirundinella & Dinoflagellate & $10 \%$ & \\
\hline Aphanizomenon flos-aquae & $\mathrm{N}$-fixing Cyanobacteria & $9 \%$ & \\
\hline Fragilaria sp. & Diatom & $6 \%$ & \\
\hline Anabaena sp. & $\mathrm{N}$-fixing Cyanobacteria & & 0.5 \\
\hline Pandorina sp. & Chlorophyte & & 0.5 \\
\hline \multicolumn{4}{|l|}{ Group 4} \\
\hline Coelastrum sp. & Chlorophyte & $26 \%$ & 0.6 \\
\hline Fragilaria sp. & Diatom & $21 \%$ & 0.6 \\
\hline Ceratium hirundinella & Dinoflagellate & $9 \%$ & \\
\hline Oocystis sp. & Chlorophyte & & 0.7 \\
\hline Asterionella Formosa & Diatom & & 0.5 \\
\hline
\end{tabular}


Table 4: Results from the environmental vectors fitting in the ordination space of the NMDS plot with variable scores along the two ordination axes (NMDS1-2), goodness-offit statistic $\mathrm{r}^{2}$ and its significance ( $p$-value). Results were sorted on $\mathrm{r}^{2}$.

\begin{tabular}{|c|c|c|c|c|c|c|c|}
\hline Variables & Abbreviation & Unit & NMDS1 & NMDS2 & $r^{2}$ & \multicolumn{2}{|c|}{$p$-Value } \\
\hline $\begin{array}{l}\text { Epilimnetic specific } \\
\text { conductance }\end{array}$ & epiSpCond & $\mathrm{mS} . \mathrm{cm}^{-1}$ & -0.87 & 0.50 & 0.60 & 0.001 & $* * *$ \\
\hline Epilimnetic $p \mathrm{H}$ & epipH & & -1.00 & 0.02 & 0.55 & 0.001 & $* * *$ \\
\hline $\begin{array}{l}\text { Epilimnetic total suspended } \\
\text { solids }\end{array}$ & epiTSS & $\mathrm{mg} \cdot \mathrm{L}^{-1}$ & -0.73 & 0.68 & 0.46 & 0.001 & $* * *$ \\
\hline $\begin{array}{l}\text { Epilimnetic total } \\
\text { phosphorus }\end{array}$ & epiTP & $\mu g . L^{-1}$ & -0.97 & 0.23 & 0.45 & 0.001 & $* * *$ \\
\hline Epilimnetic chlorophyll $a$ & epiChla & $\mu \mathrm{g} . \mathrm{L}^{-1}$ & -0.98 & -0.21 & 0.44 & 0.001 & $* * *$ \\
\hline Epilimnetic total nitrogen & epiTN & $\mu \mathrm{g} . \mathrm{L}^{-1}$ & -0.95 & 0.30 & 0.42 & 0.001 & $* * *$ \\
\hline Epilimnetic turbidity & epiTurbidity & NTU & -0.80 & 0.60 & 0.42 & 0.001 & $* * *$ \\
\hline $\begin{array}{l}\text { Pacific Decadal Oscillation } \\
\text { index }\end{array}$ & PDO & & -0.81 & 0.59 & 0.41 & 0.002 & $* *$ \\
\hline Hypolimnetic total nitrogen & hypoTN & $\mu \mathrm{g} . \mathrm{L}^{-1}$ & -0.81 & -0.59 & 0.33 & 0.002 & $* *$ \\
\hline $\begin{array}{l}\text { Epilimnetic nitrogen to } \\
\text { phosphorus ratio }\end{array}$ & epiNP & & 0.84 & -0.54 & 0.29 & 0.005 & $* *$ \\
\hline $\begin{array}{l}\text { Inflow soluble reactive } \\
\text { phosphorus }\end{array}$ & inflowSRP & $\mu \mathrm{g} . \mathrm{L}^{-1}$ & -0.93 & 0.36 & 0.28 & 0.008 & $* *$ \\
\hline $\begin{array}{l}\text { Hypolimnetic total } \\
\text { phosphorus }\end{array}$ & hypoTP & $\mu \mathrm{g} . \mathrm{L}^{-1}$ & -0.95 & -0.31 & 0.22 & 0.006 & $* *$ \\
\hline $\begin{array}{l}\text { Epilimnetic percent } \\
\text { saturation of dissolved } \\
\text { oxygen }\end{array}$ & epiDOpct & $\%$ & -0.89 & -0.45 & 0.18 & 0.034 & $*$ \\
\hline Air temperature & airTemp & ${ }^{\circ} \mathrm{C}$ & 0.44 & -0.90 & 0.16 & 0.063 & . \\
\hline $\begin{array}{l}\text { Epilimnetic water } \\
\text { temperature }\end{array}$ & epiTemp & ${ }^{\circ} \mathrm{C}$ & -0.76 & -0.65 & 0.14 & 0.087 & . \\
\hline $\begin{array}{l}\text { Hypolimnetic soluble } \\
\text { reactive phosphorus }\end{array}$ & hypoSRP & $\mu g . L^{-1}$ & -0.96 & -0.27 & 0.12 & 0.107 & \\
\hline $\begin{array}{l}\text { Epilimnetic soluble reactive } \\
\text { phosphorus }\end{array}$ & epiSRP & $\mu g . L^{-1}$ & -0.82 & 0.57 & 0.11 & 0.141 & \\
\hline Multivariate ENSO index & MEI & & -0.98 & 0.19 & 0.10 & 0.183 & \\
\hline Solar irradiation & Solarrad & $\mathrm{W} \cdot \mathrm{m}^{-2}$ & 0.19 & -0.98 & 0.08 & 0.245 & \\
\hline Wind speed $(u)$ & Windsp & $\mathrm{m} \cdot \mathrm{s}^{-1}$ & -0.61 & 0.79 & 0.07 & 0.291 & \\
\hline Wind direction $(v)$ & Winddir & degree & 0.33 & -0.95 & 0.07 & 0.296 & \\
\hline Rainfall & Rain & $\mathrm{mm}$ & 0.11 & 0.99 & 0.04 & 0.516 & \\
\hline Inflow total phosphorus & inflowTP & $\mu g . L^{-1}$ & -1.00 & 0.10 & 0.03 & 0.599 & \\
\hline Inflow total nitrogen & inflowTN & $\mu \mathrm{g} . \mathrm{L}^{-1}$ & 0.93 & 0.36 & 0.03 & 0.577 & \\
\hline
\end{tabular}

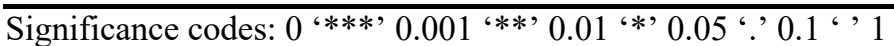
$p$-values based on 1000 permutations. 
Figures 


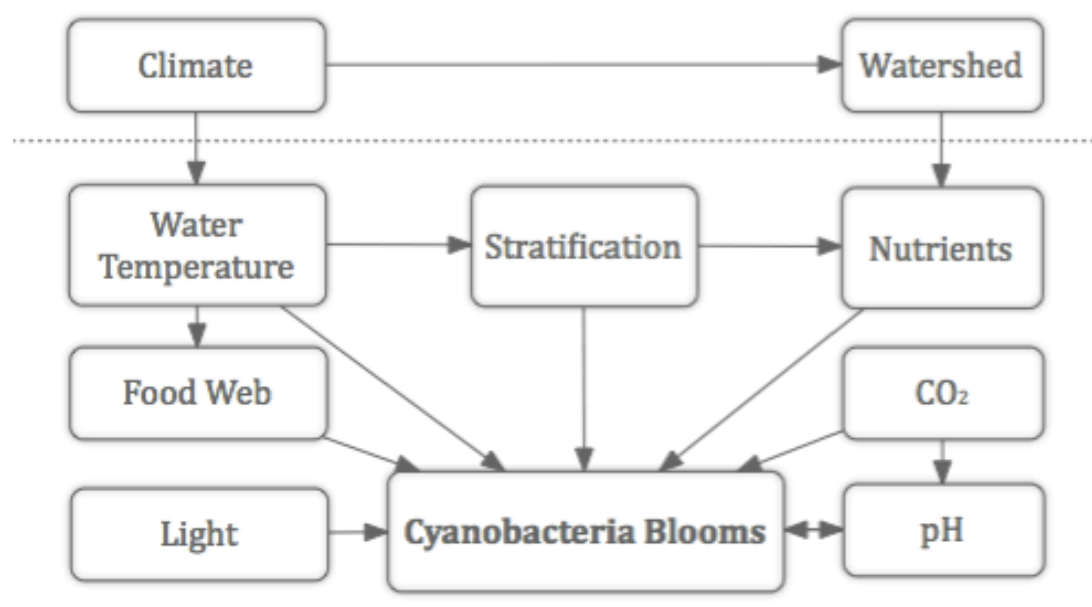

Figure 1: Conceptual diagram showing the major factors that affect cyanobacteria blooms.

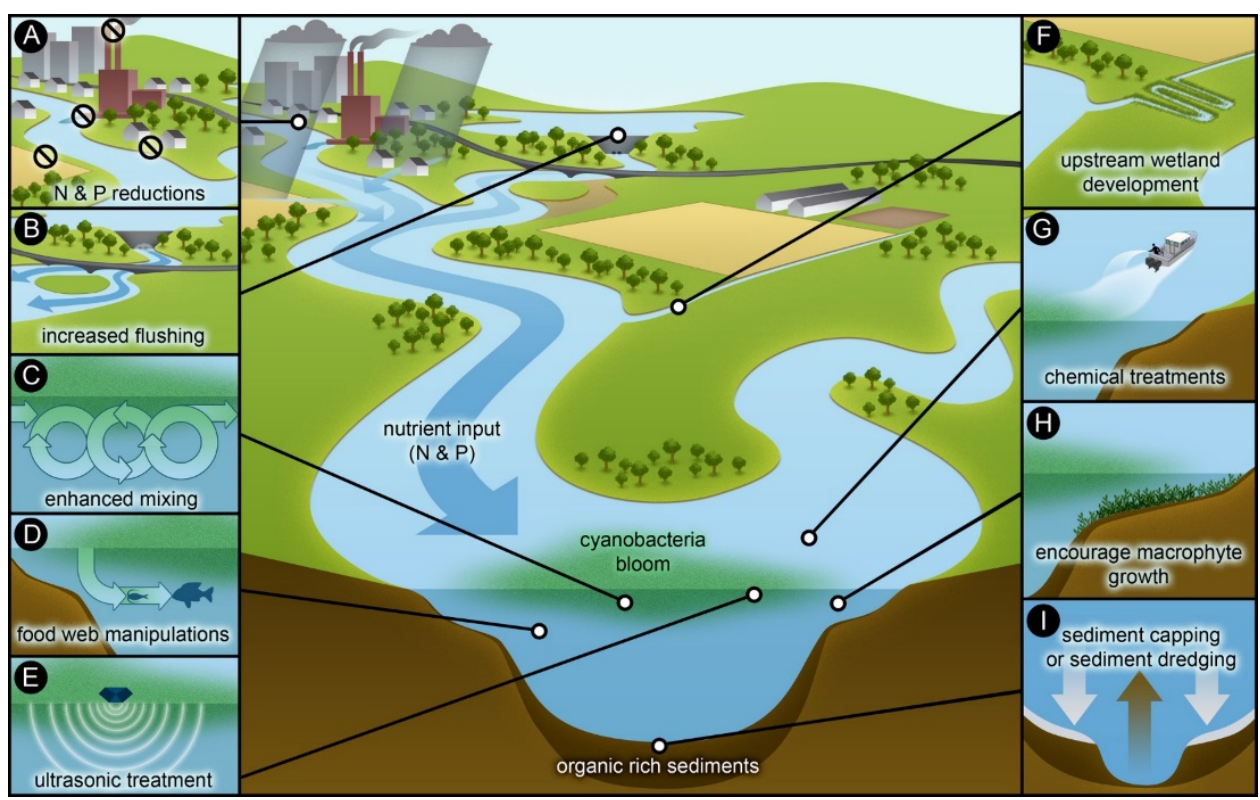

Figure 2: Conceptual illustration of various approaches currently in use to control cyanobacteria blooms (from Paerl et al., 2016). 


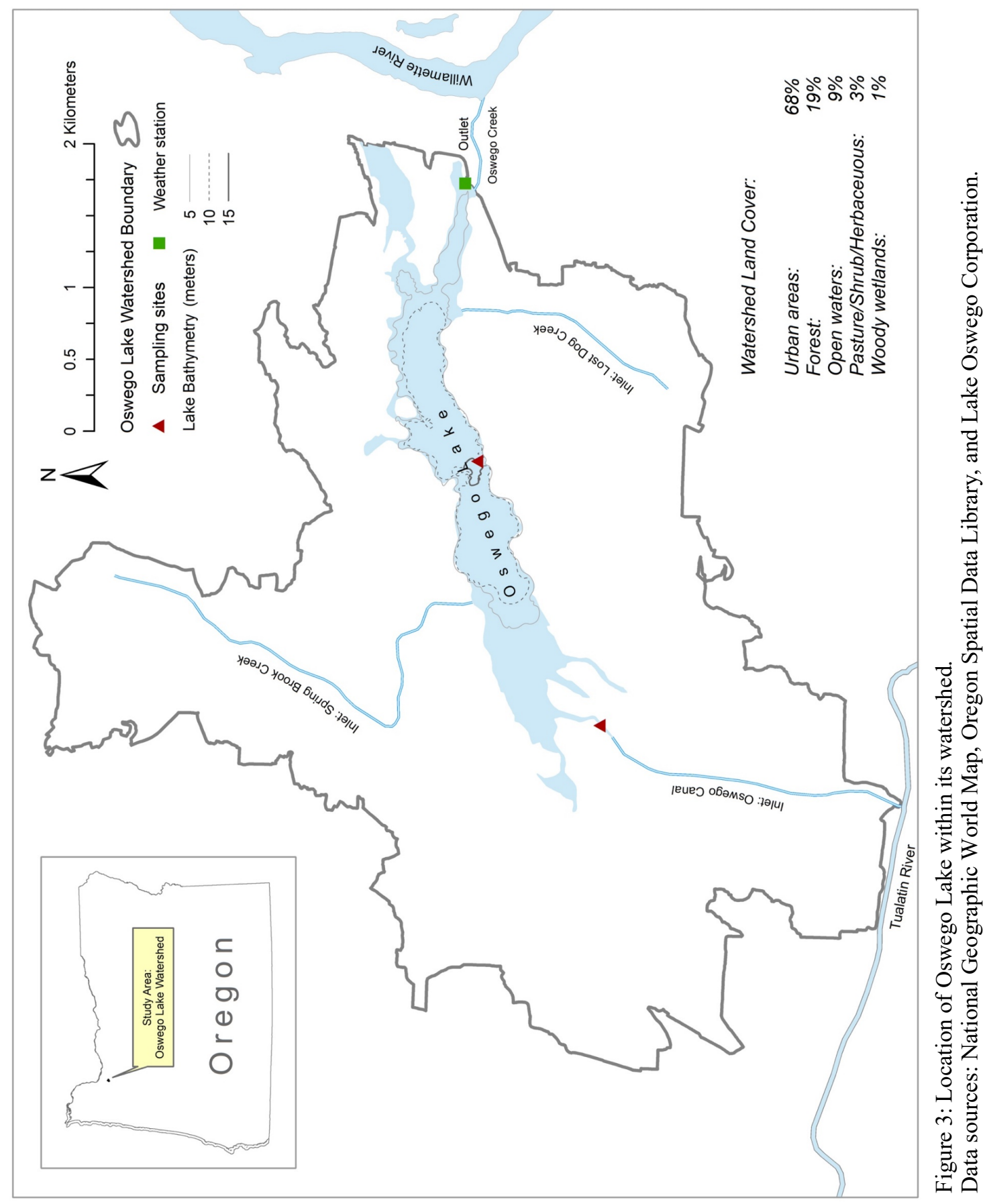


(A)

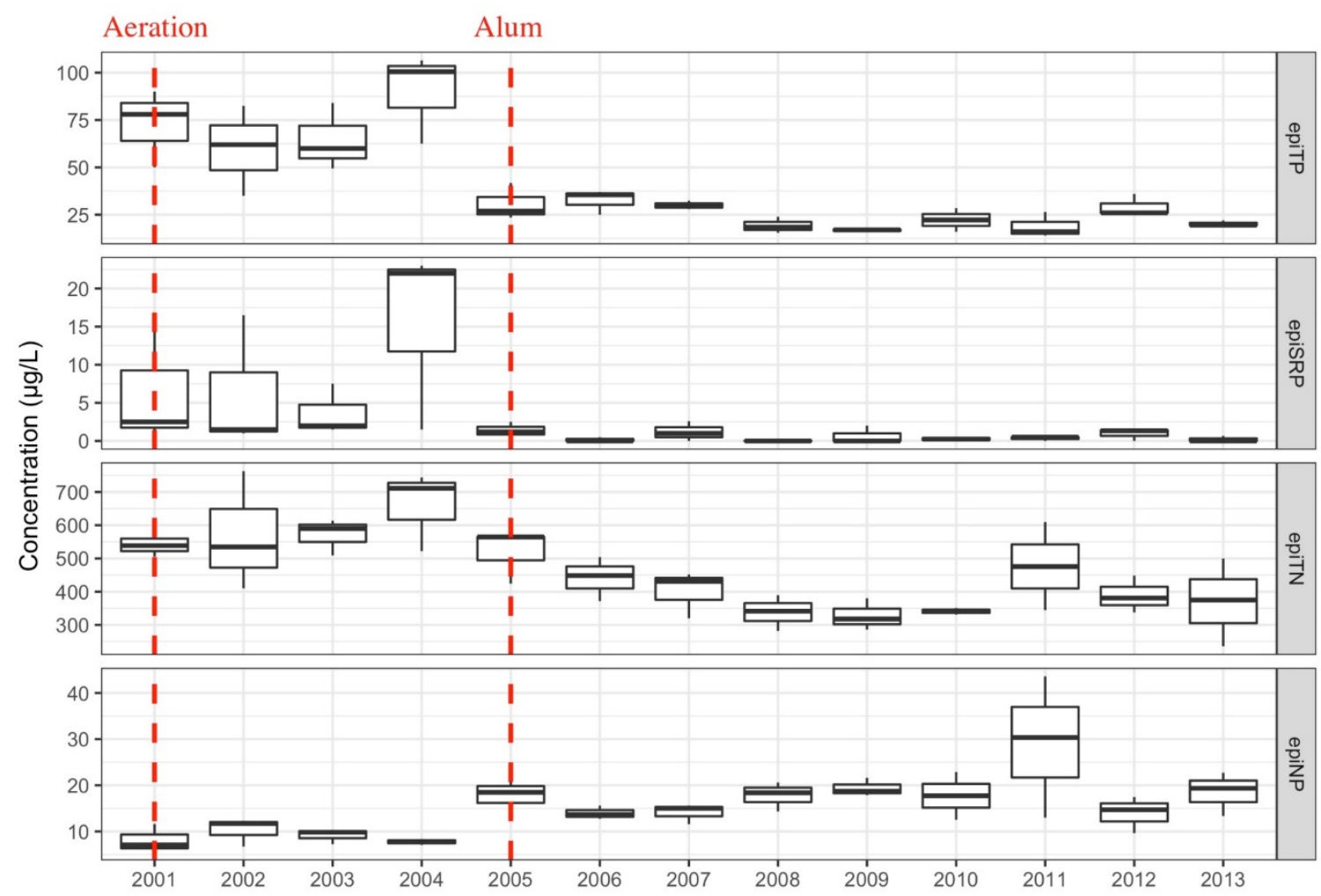

Figure 4: Boxplots showing year-to-year variations of the selected environmental variables between July and September from 2001 to 2013 in the deep basin of Oswego Lake. (A) epilimnetic nutrients. Figure continued on the following pages.

The box includes the data between first and third quantiles and the median (black bar). The upper whisker extends to the largest value no further than 1.5 IQR (the interquartile range), while the lower whisker extends to the smallest value at the most 1.5 IQR.

Abbreviations: epi - epilimnion; hypo - hypolimnion; TP - total phosphorus; SRP - soluble reactive phosphorus; TN - total nitrogen; NP - nitrogen to phosphorus ratio; Temp - temperature; SpCond specific conductance; DOpct - percent saturation of dissolved oxygen; TSS - total suspended solids; Chla chlorophyll $a$; MEIrank - ranks of the multivariate ENSO index (MEI); PDO - the PDO index based on Mantua et al. (1997); Windsp - wind speed (wind component $u$ ); Winddir - wind direction (wind component $v$ ); Solarrad - solar radiation. 
(B)

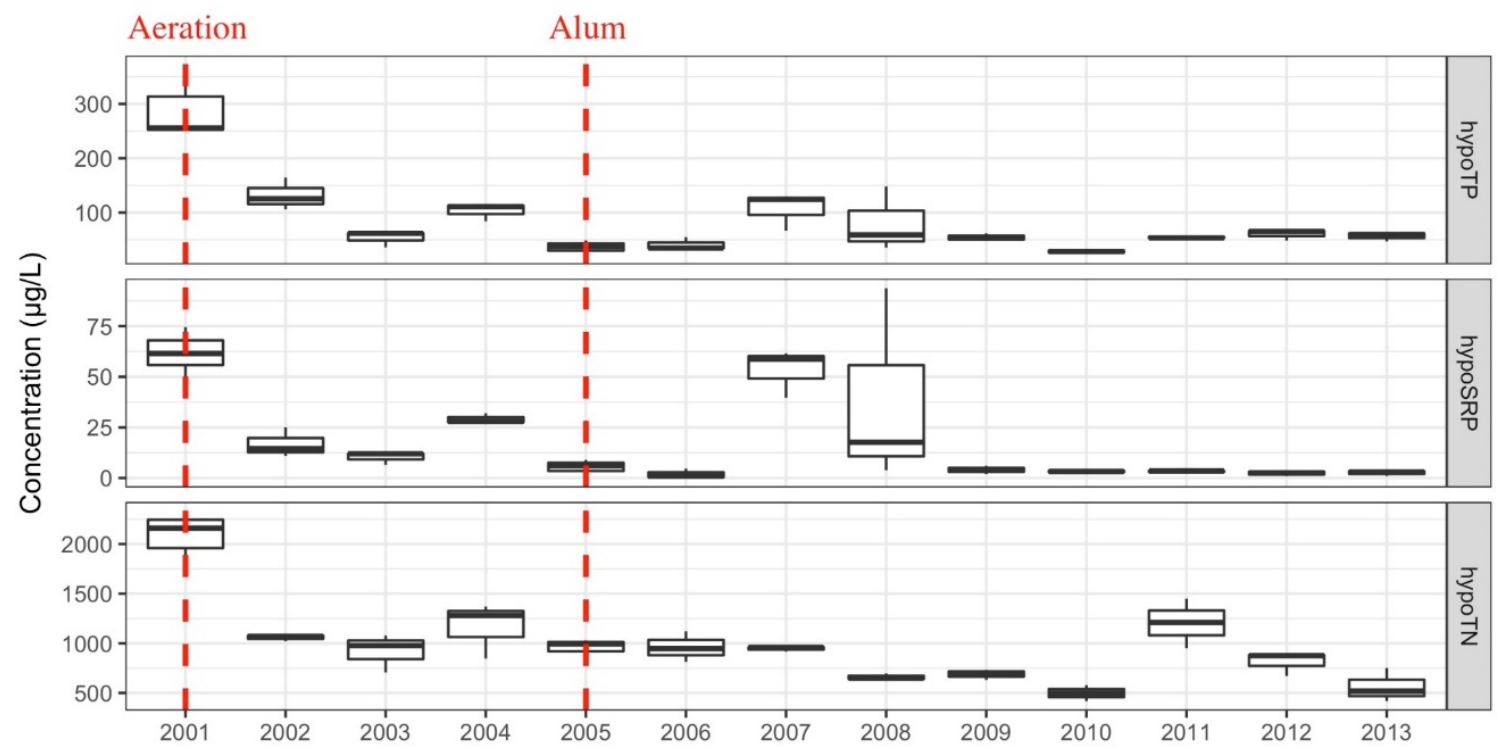

(C)

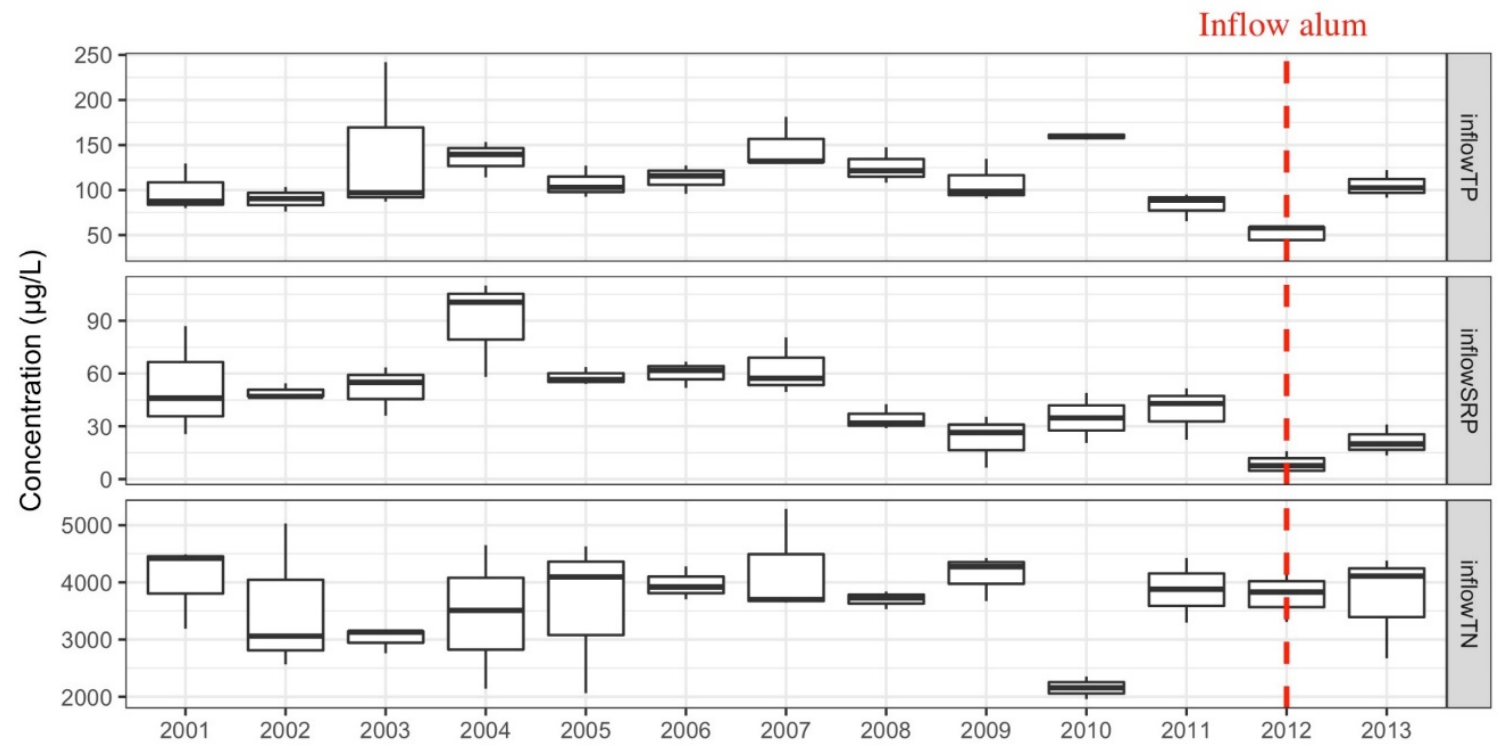

Figure 4: Continued. (B) hypolimnetic nutrients, (C) inflow nutrients. 
(D)
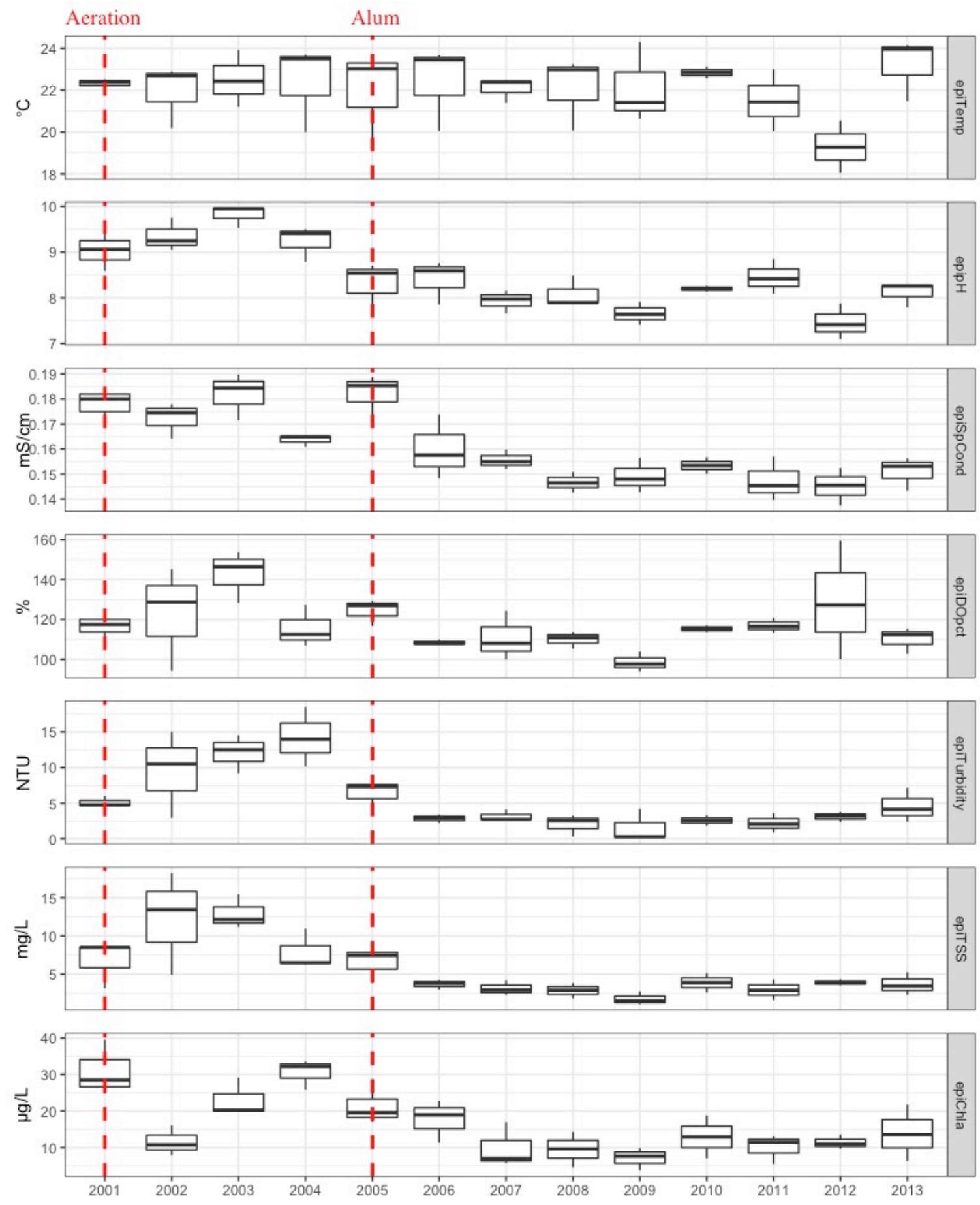

Figure 4: Continued. (D) other epilimnetic water quality variables. 
(E)
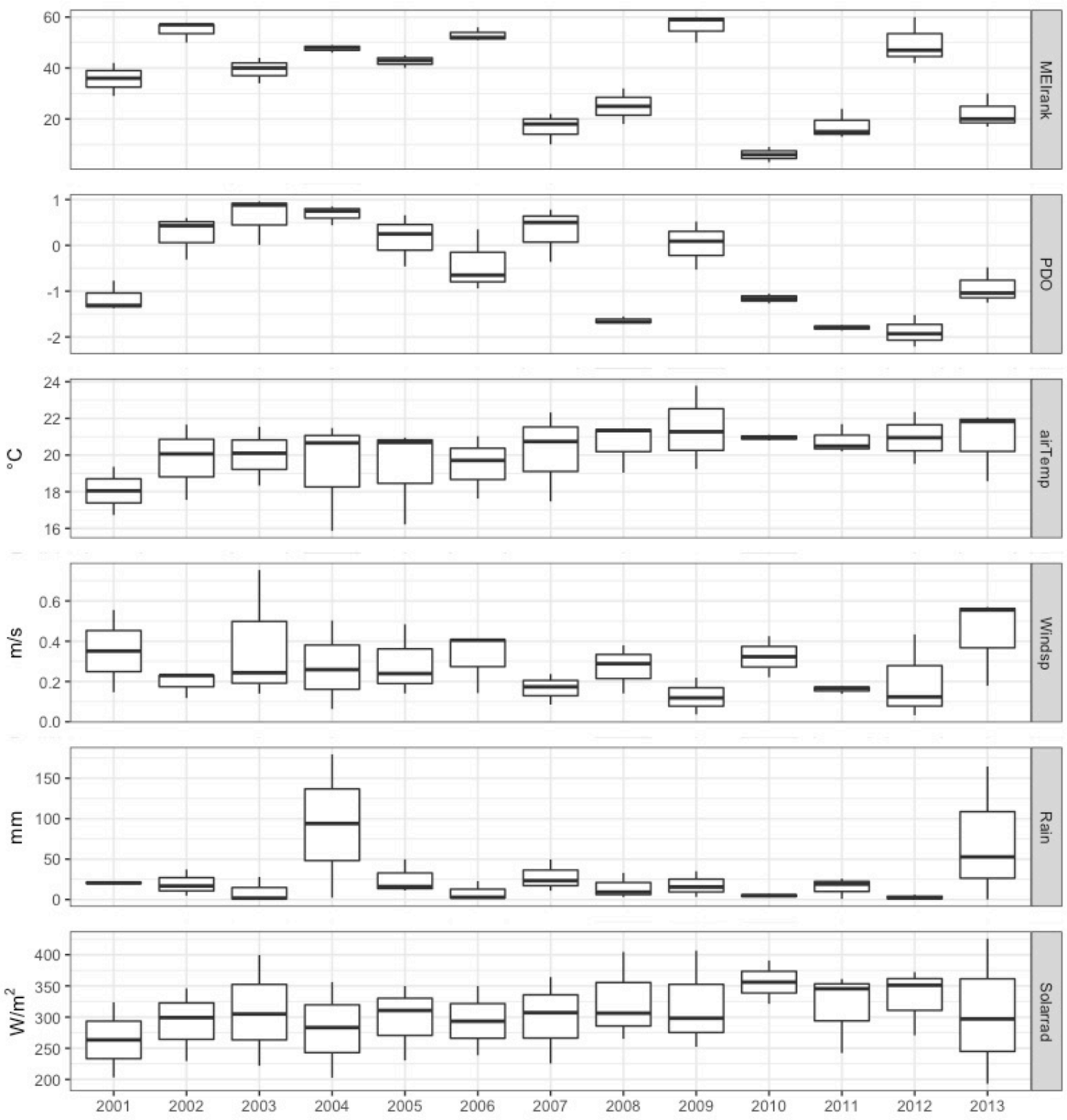

Figure 4: Continued. (E) climatic and meteorological variables. 

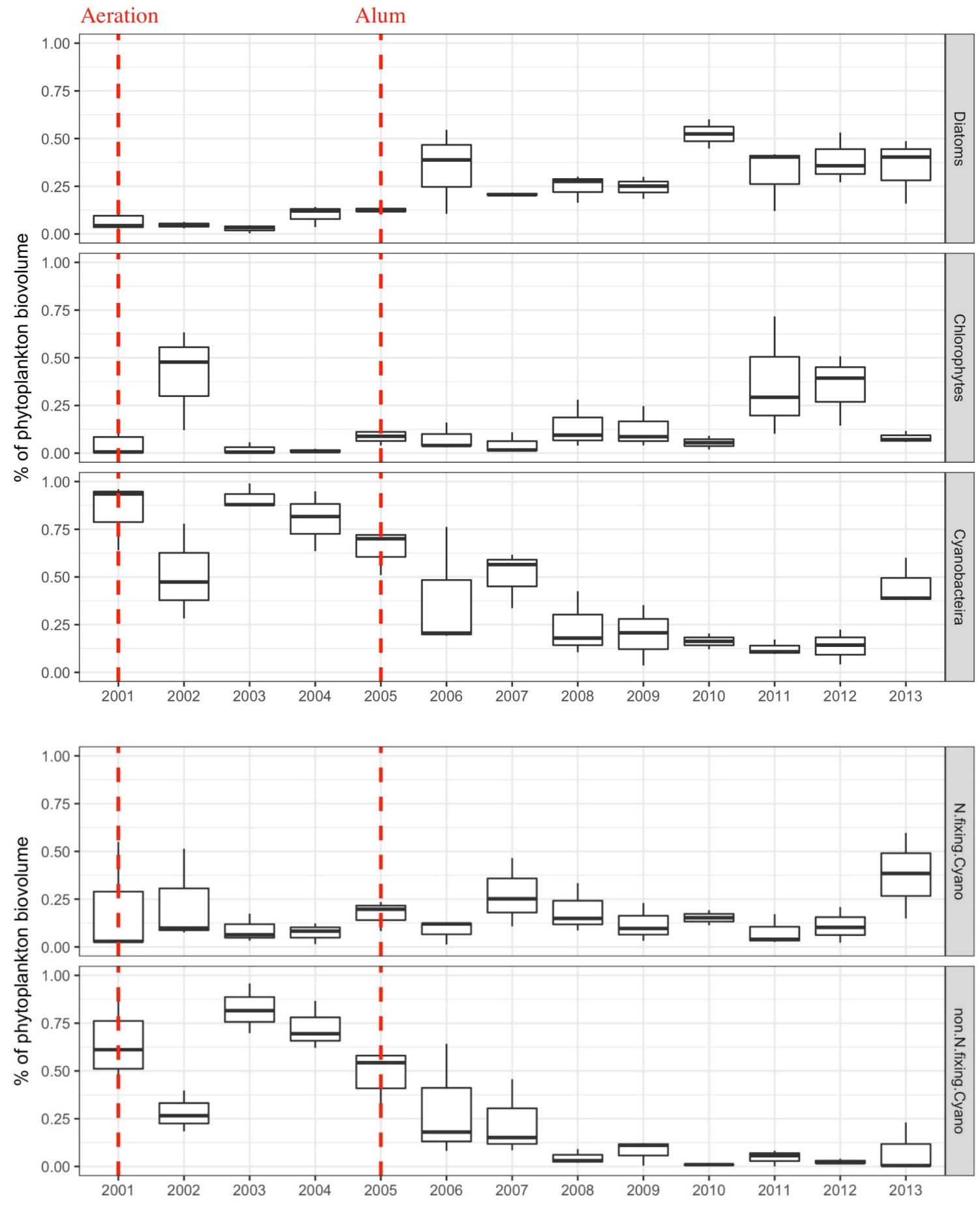

Figure 5: Boxplots showing year-to-year variations of the phytoplankton assemblages among the major taxonomic groups between July and September from 2001 to 2013 in the deep basin of Oswego Lake. 

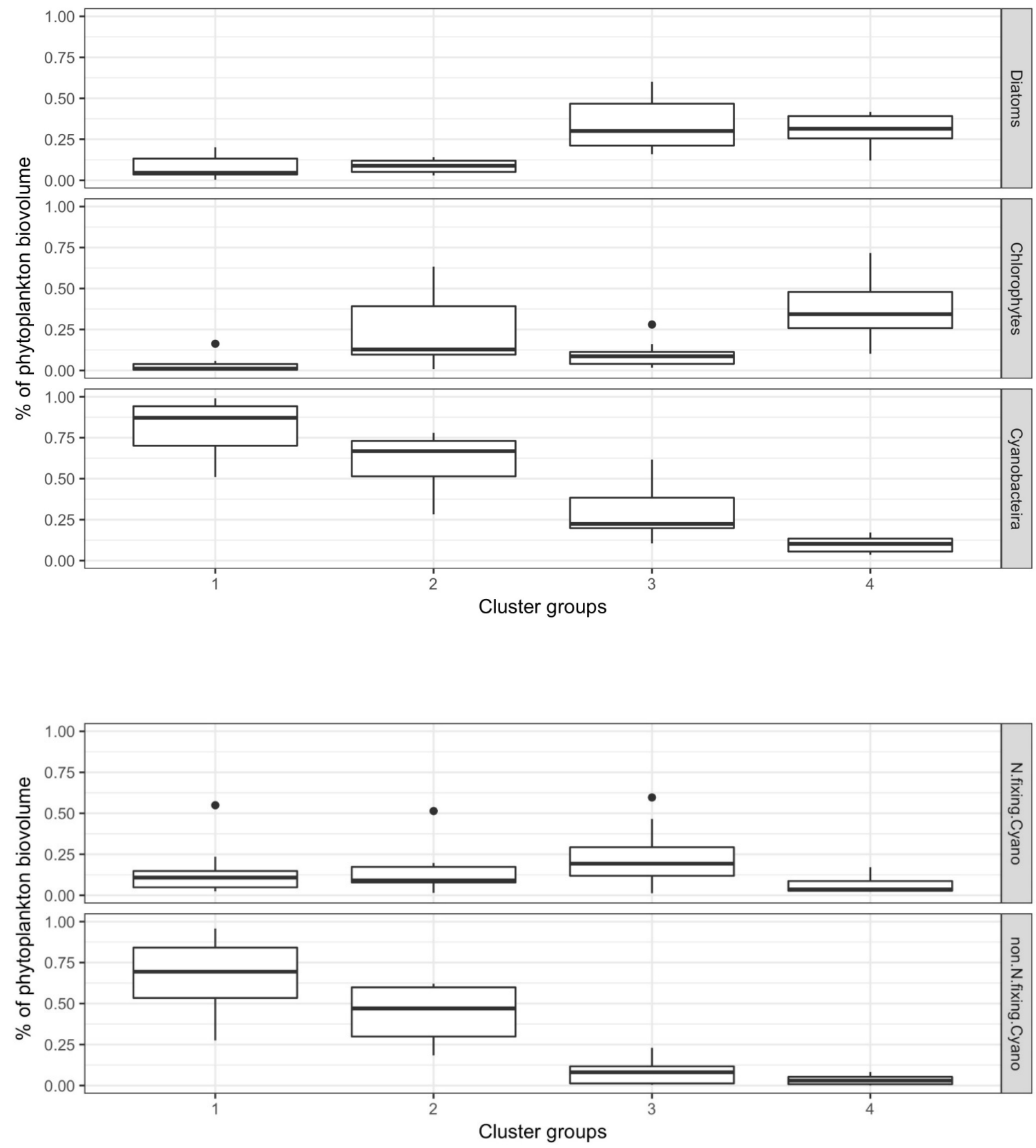

Figure 6: Boxplots showing comparison of relative abundance of the phytoplankton taxonomic groups among 4 cluster groups based on the cluster analysis. 

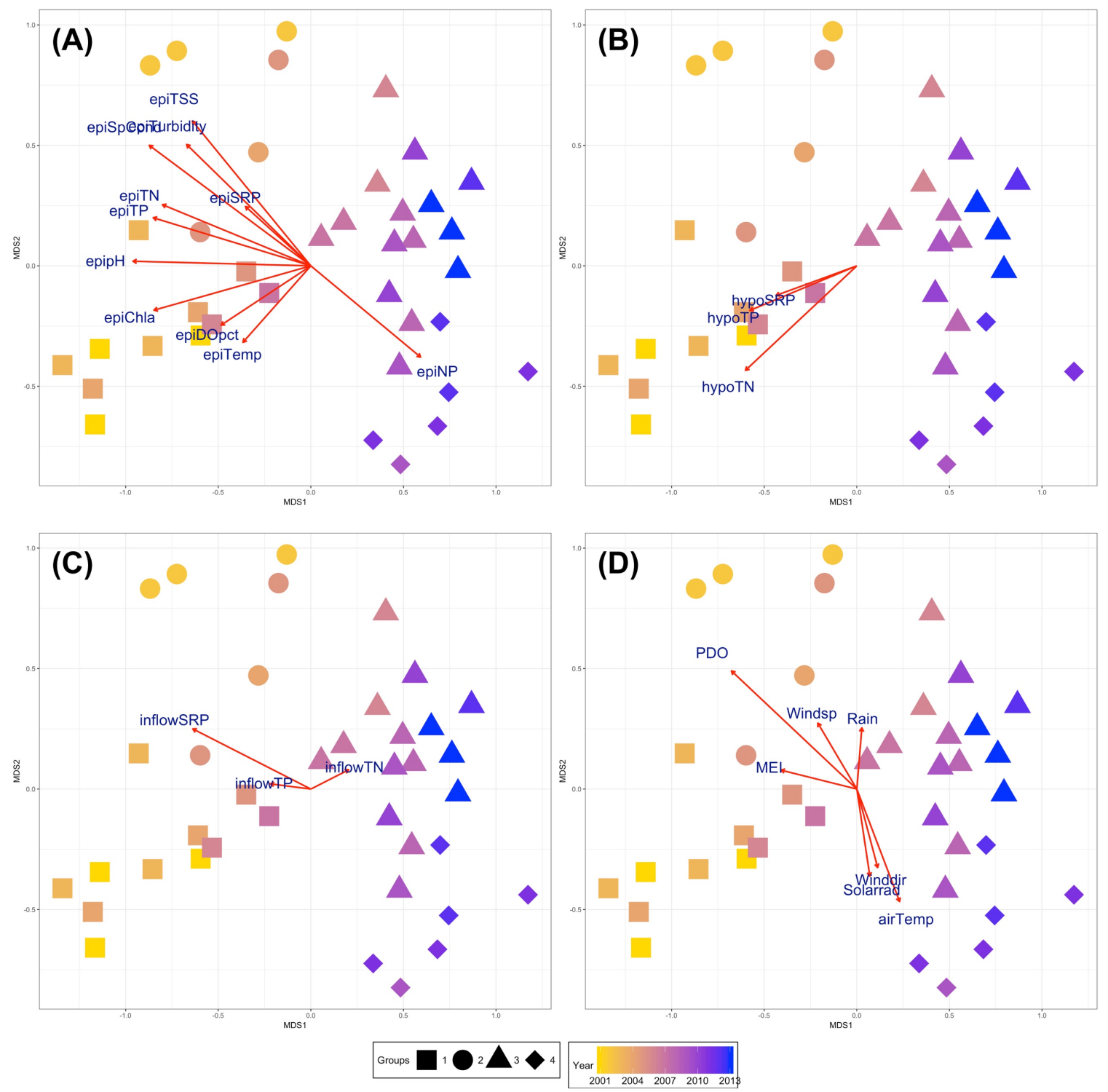

Figure 7: Plots of non-metric multidimensional scaling (NMDS) analysis showing temporal variation of the phytoplankton assemblages between July and September from 2001 to 2013 in the deep basin of Oswego Lake, superimposed with the cluster groups and with relation to major environmental variables of epilimnion (A), hypolimnion (B), Tualatin River inflow (C), and climate and meteorological conditions (D). Figure continued on the next page. 

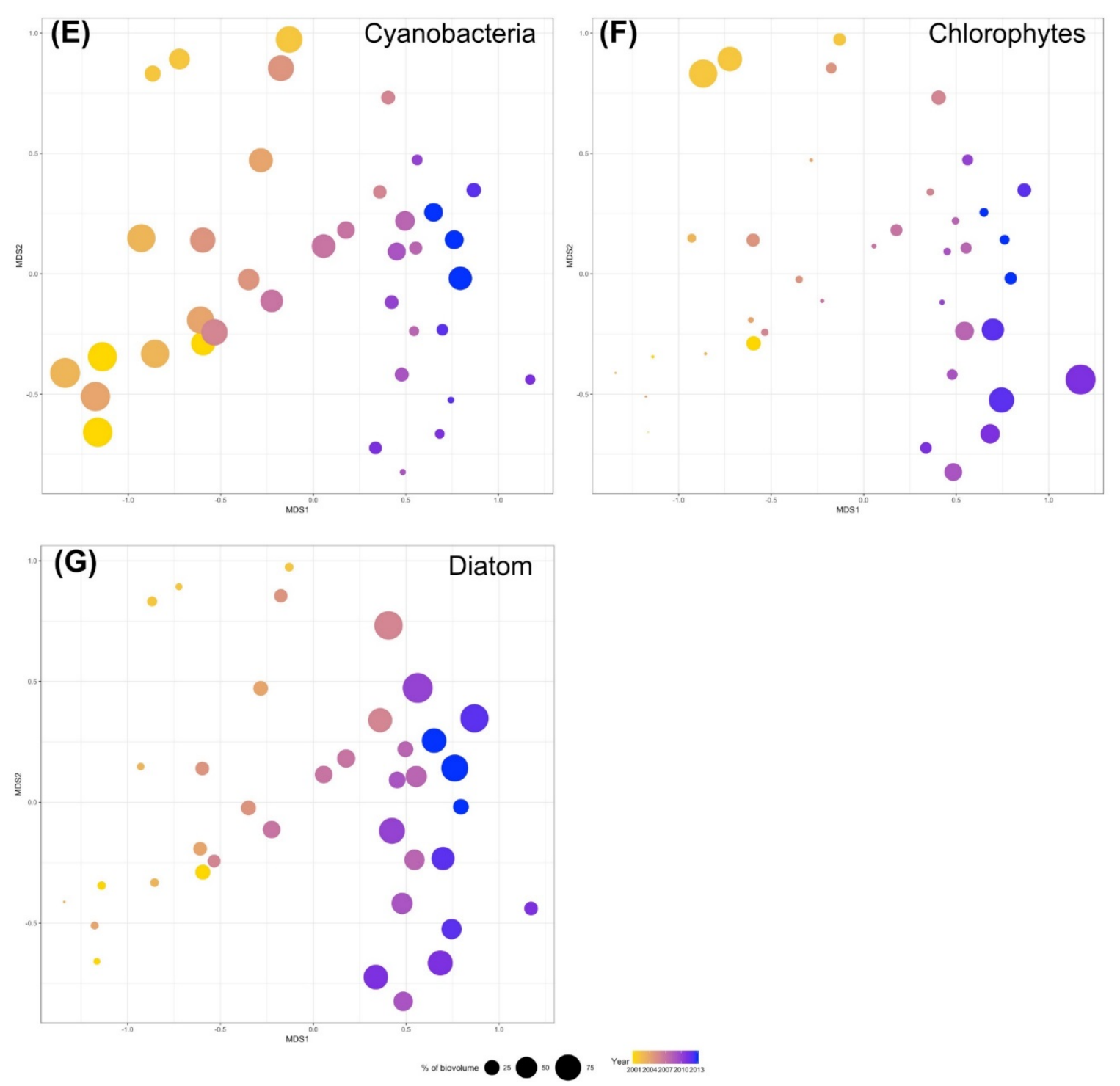

Figure 7 Continued. (E)-(G) are the same NMDS plot superimposed with \% of cyanobacteria (E), chlorophytes $(\mathrm{F})$ and diatoms $(\mathrm{G})$ in each sample (bubble size is proportional to the relative abundance of total phytoplankton biovolume). 


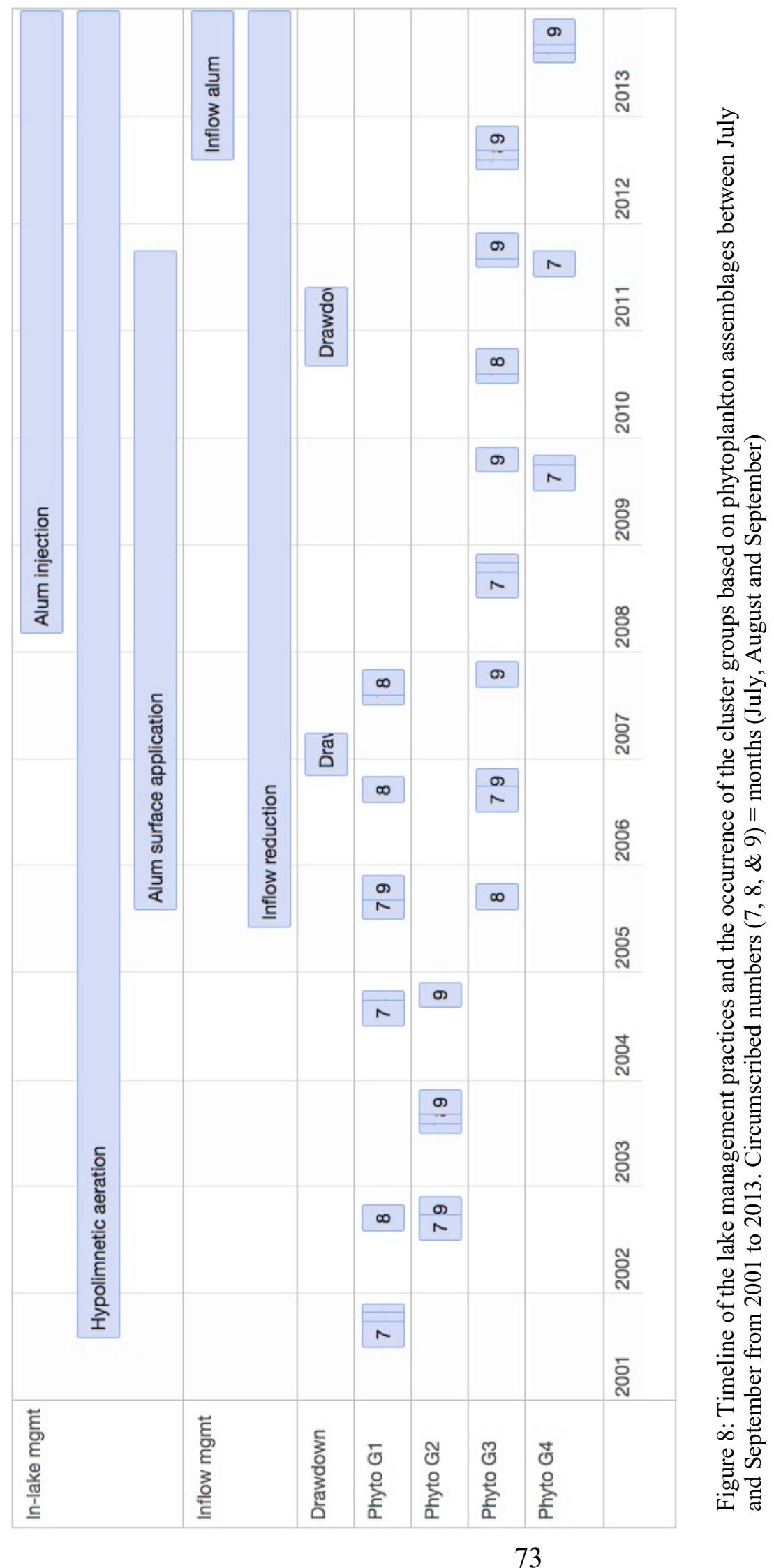




\section{References}

Abrams, M. M., \& Jarrell, W. M. (1995). Soil phosphorus as a potential nonpoint source for elevated stream phosphorus levels. Journal of Environmental Quality, 24(1), $132-138$.

Adrian, R., O'Reilly, C. M., Zagarese, H., Baines, S. B., Hessen, D. O., Keller, W., ... Winder, M. (2009). Lakes as sentinels of climate change. Limnology and Oceanography, 54(6), 2283-2297. http://doi.org/10.4319/lo.2009.54.6_part_2.2283

Aguiar, T. R., Rasera, K., Parron, L. M., Brito, A. G., \& Ferreira, M. T. (2015). Nutrient removal effectiveness by riparian buffer zones in rural temperate watersheds: The impact of no-till crops practices. Agricultural Water Management, 149, 74-80. http://doi.org/10.1016/j.agwat.2014.10.031

APHA. (2012). Standard methods for the examination of water and wastewater. American Public Health Association.

Badger, M. R., \& Price, G. D. (2003). CO2 concentrating mechanisms in cyanobacteria: molecular components, their diversity and evolution. Journal of Experimental Botany, 54(383), 609-622. http://doi.org/10.1093/jxb/erg076

Bakker, E. S., \& Hilt, S. (2016). Impact of water-level fluctuations on cyanobacterial blooms: options for management. Aquatic Ecology, 50(3), 485-498. http://doi.org/10.1007/s10452-015-9556-X

Beutel, M. W., \& Horne, A. J. (1999). A Review of the Effects of Hypolimnetic Oxygenation on Lake and Reservoir Water Quality. Lake and Reservoir Management, 15(4), 285-297. http://doi.org/10.1080/07438149909354124

Birch, S., \& McCaskie, J. (1999). Shallow urban lakes: a challenge for lake management. Hydrobiologia, 395-396, 365-377. http://doi.org/10.1023/A:1017099030774

Bonsal, B. R., Prowse, T. D., Duguay, C. R., \& Lacroix, M. P. (2006). Impacts of largescale teleconnections on freshwater-ice break/freeze-up dates over Canada. Journal of Hydrology, 330(1-2), 340-353. http://doi.org/10.1016/j.jhydrol.2006.03.022

Bormans, M., Maršálek, B., \& Jančula, D. (2016). Controlling internal phosphorus loading in lakes by physical methods to reduce cyanobacterial blooms: a review. Aquatic Ecology, 50(3), 407-422. http://doi.org/10.1007/s10452-015-9564-x

Bray, R. J., \& Curtis, J. T. (1957). An Ordination of the Upland Forest Communities of Southern Wisconsin. Ecological Monographs, 27(4), 325-349.

Butusov, M., \& Jernelöv, A. (2013). Phosphorus in the Organic Life: Cells, Tissues, Organisms. In Phosphorus: An Element that could have been called Lucifer (Vol. 9, pp. 13-18). New York: Springer. http://doi.org/10.1007/978-1-4614-6803-5

Carey, C. C., Ibelings, B. W., Hoffmann, E. P., Hamilton, D. P., \& Brookes, J. D. (2012). Eco-physiological adaptations that favour freshwater cyanobacteria in a changing climate. Water Research, 46(5), 1394-1407. 
http://doi.org/10.1016/j.watres.2011.12.016

Carlson, R. E. (1977). A trophic state index for lakes. Limnology and Oceanography, 22(2), 361-369. http://doi.org/10.4319/lo.1977.22.2.0361

Carmichael, W. W. (1997). The cyanotoxins. In Advances in botanical research (Vol. 27, pp. 211-256). Academic Press.

Carpenter, S. R. (2008). Phosphorus control is critical to mitigating eutrophication. In Proceedings of the National Academy of Sciences (Vol. 105, pp. 11039-11040). http://doi.org/10.1073/pnas.0806112105

Carpenter, S. R., Caraco, N. F., Correll, D. L., W.Howarth, R., Sharpley, A. N., \& Smith, V. H. (1998). Nonpoint pollution of surface waters with phosphorus and nitrogen. Ecological Applications, 8(3), 559-568. http://doi.org/10.1890/10510761(1998)008[0559:NPOSWW]2.0.CO;2

Carpenter, S. R., Kitchell, J. F., \& Hodgson, J. R. (1985). Cascading trophic interactions and lake productivity. BioScience, 35(10), 634-639.

Carslaw, D., \& Ropkins, K. (2018). Package ' openair .'

Cavole, L. M., Demko, A. M., Diner, R. E., Giddings, A., Koester, I., Pagniello, C. M. L. S., ... Franks, P. J. S. (2016). Biological Impacts of the 2013-2015 Warm-Water Anomaly in the Northeast Pacific: Winners, Losers, and the Future. Oceanography, 29(2). http://doi.org/10.5670/oceanog.2016.32

Clarke, K. R. (1993). Non-parametric multivariate analyses of changes in community structure. Australian Journal of Ecology, 18, 117-143.

Cooke, G. D., Welch, E. B., Peterson, S., \& Nichols, S. A. (2005). Restoration and management of lakes and reservoirs (3rd ed.). Boca Raton: CRC press.

Davis, T. W., Berry, D. L., Boyer, G. L., \& Gobler, C. J. (2009). The effects of temperature and nutrients on the growth and dynamics of toxic and non-toxic strains of Microcystis during cyanobacteria blooms. Harmful Algae, 8(5), 715-725. http://doi.org/10.1016/j.hal.2009.02.004

Dodds, W., K, Bouska, W. W., Eitzmann, J. L., Pilger, T. J., Pitts, K. L., Riley, A. J., ... Thornbrugh, D. J. (2009). Eutrophication of U.S. Freshwaters: Analysis of Potential Economic Damages. Environmental Science \& Technology, 43(1), 12-19. http://doi.org/10.1021/es801217q

Downing, J. A., Watson, S. B., \& McCauley, E. (2001). Predicting Cyanobacteria dominance in lakes. Canadian Journal of Fisheries and Aquatic Sciences, 58(10), 1905-1908. http://doi.org/10.1139/f01-143

Drenner, R. W., Baca, R. M., Gilroy, J. S., Ernst, M. R., Jensen, D. J., \& Marshall, D. H. (2002). Community responses to piscivorous largemouth bass: A biomanipulation experiment. Lake and Reservoir Management, 18(1), 44-51. http://doi.org/10.1080/07438140209353928

Dufrene, M., \& Legendre, P. (1997). Species Assemblages and Indicator Species : The 
Need for a Flexible Asymmetrical Approach. Ecological Monographs, 67(3), 345366.

Elliott, J. A. (2010). The seasonal sensitivity of Cyanobacteria and other phytoplankton to changes in flushing rate and water temperature. Global Change Biology, 16(2), 864876. http://doi.org/10.1111/j.1365-2486.2009.01998.x

Elser, J. J., Bracken, M. E. S., Cleland, E. E., Gruner, D. S., Harpole, W. S., Hillebrand, H., ... Smith, J. E. (2007). Global analysis of nitrogen and phosphorus limitation of primary producers in freshwater, marine and terrestrial ecosystems. Ecology Letters, 10(12), 1135-1142. http://doi.org/10.1111/j.1461-0248.2007.01113.x

EPA. (2015). A Compilation of Cost Data Associated with the Impacts and Control of Nutrient Pollution. Retrieved from http://www2.epa.gov/sites/production/files/201504/documents/nutrient-economics-report-2015.pdf

Foster, L. O. (2009). Lake Oswego. Charleston, S.C.: Arcadia Publishing.

Franczyk, J., \& Chang, H. (2009). The effects of climate change and urbanization on the runoff of the Rock Creek basin in the Portland metropolitan area, Oregon, USA. Hydrological Processes, 23(6), 805-815. http://doi.org/10.1002/hyp

Gensemer, R. W., \& Playle, R. C. (1999). The bioavailability and toxicity of aluminum in aquatic environments. Critical Reviews in Environmental Science and Technology, 29(4), 315-450. http://doi.org/10.1080/10643389991259245

Gibbons, H., \& Welch, E. B. (2004). Oswego Lake Limnological Analysis into the 2004 Cyanobacteria Bloom Event. A report to the Oswego Lake Corporation, Lake Oswego, Oregon.

Gibbons, M. (2013). Microscopic Methods: Taxonomic Analyses of Phytoplankton Samples. WATER Environmental Services, Inc.

Glazer, A. N. (1997). Structure and molecular organization of the photosynthetic accessory pigments of cyanobacteria and red algae. Molecular and Cellular Biochemistry, 18(2), 125-140.

Godomski, D. (2013). Laboratory Methods for TP, SRP, and TN. From Lillian's personal communication.

Golubic, S., \& Seong-Joo, L. (1999). Early cyanobacterial fossil record: Preservation, palaeoenvironments and identification. European Journal of Phycology, 34(4), 339348. http://doi.org/10.1080/09670269910001736402

Grange, S. K. (2014). Averaging wind speeds and directions. http://doi.org/10.13140/RG.2.1.3349.2006

Grime, J. P. (1977). Evidence for the Existence of Three Primary Strategies in Plants and Its Relevance to Ecological and Evolutionary Theory. The American Naturalist, 111(982), 1169-1194.

Hamilton, D. P., Salmaso, N., \& Paerl, H. W. (2016). Mitigating harmful cyanobacterial blooms: strategies for control of nitrogen and phosphorus loads. Aquatic Ecology, 
50(3), 351-366. http://doi.org/10.1007/s10452-016-9594-z

Harris, G. P., \& Baxter, G. (1996). Interannual variability in phytoplankton biomass and species composition in a subtropical reservoir. Freshwater Biology, 35(3), 545-560.

Hatch, L. K., Reuter, J. E., \& Goldman, C. R. (1999). Relative importance of streamborne particulate and dissolved phosphorus fractions to Lake Tahoe phytoplankton. Canadian Journal of Fisheries and Aquatic Sciences, 56(12), 2331-2339. http://doi.org/10.1139/f99-166

Heinzmann, B., \& Chorus, I. (1994). Restoration Concept for Lake Tegei, a Major Drinking and Bathing Water Resource in a Densely Populated Area. Environmental Science and Technology, 28(8), 1410-1416. http://doi.org/10.1021/es00057a006

Horppila, J., Peltonen, H., Malinen, T., Luokkanen, E., \& Kairesalo, T. (1998). Topdown or Bottom-up Effects by Fish: Issues of Concern in Biomanipulation of Lakes. Restoration Ecology, 6(1), 20-28. http://doi.org/10.1046/j.1526-100x.1998.00613.x

Huisman, J., \& Hulot, F. D. (2005). Population dynamics of harmful cyanobacteria. In J. Huisman, H. C. P. Matthijs, \& P. M. Visser (Eds.), Harmful cyanobacteria (Vol. 3, pp. 143-176). Dordrecht, The Netherlands: Springer.

Huser, B. J., Egemose, S., Harper, H., Hupfer, M., Jensen, H., Pilgrim, K. M., ... Futter, M. (2016). Longevity and effectiveness of aluminum addition to reduce sediment phosphorus release and restore lake water quality. Water Research, 97, 122-132. http://doi.org/10.1016/j.watres.2015.06.051

Huser, B. J., Futter, M., Lee, J. T., \& Perniel, M. (2016). In-lake measures for phosphorus control: The most feasible and cost-effective solution for long-term management of water quality in urban lakes. Water Research, 97, 142-152. http://doi.org/10.1016/j.watres.2015.07.036

Hutchinson, G. E. (1961). The paradox of the plankton. The American Naturalist, 95(882), 137-145.

Ibelings, B. W., Bormans, M., Fastner, J., \& Visser, P. M. (2016). CYANOCOST special issue on cyanobacterial blooms: synopsis - a critical review of the management options for their prevention, control and mitigation. Aquatic Ecology, 50(3), 595605. http://doi.org/10.1007/s10452-016-9596-x

IPCC. (2007). Climate Change 2007: The Physical Science Basis. Contribution of working group I to the fourth assessment report of the intergovernmental panel on climate change. (S. Solomon, D. Qin, M. Manning, Z. Chen, M. Marquis, K. B. Averyt, ... H. L. Miller, Eds.). Cambridge: Cambridge University Press. http://doi.org/10.1038/446727a

IPCC. (2014). Climate change 2014: Synthesis Report. Contribution of Working Groups I, II and III to the fifth assessment report of the Intergovernmental Panel on Climate Change. (R. K. Pachauri \& L. A. Meyer, Eds.). Geneva, Switzerland: IPCC.

Jernelov, A. (1970). Phosphate reduction in lakes by precipitation with aluminum sulfate. In 5th International Water Pollution Research Conference. New York: Pergamon 
Press.

Jöhnk, K. D., Huisman, J., Sharples, J., Sommeijer, B., Visser, P. M., \& Stroom, J. M. (2008). Summer heatwaves promote blooms of harmful cyanobacteria. Global Change Biology, 14(3), 495-512. http://doi.org/10.1111/j.1365-2486.2007.01510.x

Johnson, B. S. (2009). Longitudinal Transport Dynamics of Phosphorus and Sediment in a Small Urban Stream. Portland State University.

Johnson, D. M. (1985). Atlas of Oregon lakes. Oregon State University Press.

Katsiapi, M., Mazaris, A. D., Charalampous, E., \& Moustaka-Gouni, M. (2012). Watershed land use types as drivers of freshwater phytoplankton structure. Hydrobiologia, 698(1), 121-131. http://doi.org/10.1007/s10750-012-1095-z

Keddy, P. A. (1992). Assembly and Response Rules: Two Goals for Predictive Community Ecology. Journal of Vegetation Science, 3(2), 157-164.

King, D. L. (1970). The Role of Carbon in Eutrophication. Journal (Water Pollution Control Federation), 42(12), 2035-2051.

Kosten, S., Huszar, V. L. M., Bécares, E., Costa, L. S., van Donk, E., Hansson, L. A., ... Scheffer, M. (2012). Warmer climates boost cyanobacterial dominance in shallow lakes. Global Change Biology, 18(1), 118-126. http://doi.org/10.1111/j.13652486.2011.02488.x

Kotak, B. G., Kenefick, S. L., Fritz, D. L., Rousseaux, C. G., Prepas, E. E., \& Hrudey, S. E. (1993). Occurrence and toxicological evaluation of cyanobacterial toxins in Alberta lakes and farm dugouts. Water Research, 27(3), 495-506.

Lewandowski, J., Schauser, I., \& Hupfer, M. (2003). Long term effects of phosphorus precipitations with alum in hypereutrophic Lake Süsser See (Germany). Water Research, 37(13), 3194-3204. http://doi.org/10.1016/S0043-1354(03)00137-4

Lewis, W. M., Wurtsbaugh, W. A., \& Paerl, H. W. (2011). Rationale for control of anthropogenic nitrogen and phosphorus to reduce eutrophication of inland waters. Environmental Science and Technology, 45(24), 10300-10305. http://doi.org/10.1021/es202401p

Liboriussen, L., Søndergaard, M., Jeppesen, E., Thorsgaard, I., Grünfeld, S., Jakobsen, T. S., \& Hansen, K. (2009). Effects of hypolimnetic oxygenation on water quality: Results from five Danish lakes. Hydrobiologia, 625(1), 157-172. http://doi.org/10.1007/s10750-009-9705-0

Livingstone, D. M. (2003). Impact of secular climate change on the thermal structure of a large temperate central European lake. Climatic Change, 57(1), 205-225.

Livingstone, D. M., \& Dokuli, M. T. (2001). Eighty years of spatially coherent Austrian lake surface temperatures and their relationship to regional air temperature and the North Atlantic Oscillation. Limnology and Oceanography, 46(5), 1220-1227. http://doi.org/10.4319/lo.2001.46.5.1220

Lund, J. W. G. (1971). An artificial alteration of the seasonal cycle of the plankton 
diatom Melosira Italica subsp. subarctica in an English lake. Journal of Ecology, 59(2), 521-533.

Magnuson, J. J., Webster, K. E., Assel, R. A., Bowser, C. J., Dillon, P. J., Eaton, J. G., ... Quinn, F. H. (1997). Potential effects of climate changes on aquatic systems: Laurentian Great Lakes and Precambrian Shield region. Hydrological Processes, 11(8), 825-871. http://doi.org/10.1002/(SICI)1099-1085(19970630)11:8<825::AIDHYP509>3.0.CO;2-G

Mantua, N. J., \& Hare, S. R. (2002). The Pacific Decadal Oscillation. Journal of Oceanography, 58(1), 35-44. http://doi.org/10.1023/A:1015820616384

Mantua, N. J., Hare, S. R., Zhang, Y., Wallace, J. M., \& Francis, R. C. (1997). A Pacific interdecadal climate oscillation with impacts on salmon production. Bulletin of the American Meteorological Society, 78(6), 1069-1079.

Mazzarella, A., Giuliacci, A., \& Liritzis, I. (2010). On the 60-month cycle of multivariate ENSO index. Theoretical and Applied Climatology, 100(1-2), 23-27. http://doi.org/10.1007/s00704-009-0159-0

McCauley, E., Downing, J. A., \& Watson, S. (1989). Sigmoid Relationships between Nutrients and Chlorophyll among Lakes. Canadian Journal of Fisheries and Aquatic Sciences, 46(7), 1171-1175. http://doi.org/10.1139/f89-152

McGowan, S., Patoine, A., Graham, M., \& Leavitt, P. (2005). Intrinsic and extrinsic controls on lake phytoplankton synchrony as illustrated by algal pigments. Internationale Vereinigung Fur Theoretische Und Angewandte Limnologie Verhandlungen, 29(2), 794-798.

Moore, B. C., \& Christensen, D. (2009). Newman Lake restoration: A case study. Part I. Chemical and biological responses to phosphorus control. Lake and Reservoir Management, 25(4), 337-350. http://doi.org/10.1080/07438140903172907

Moore, B. C., Christensen, D., \& Richter, A. C. (2009). Newman Lake restoration: A case study. Part II. Microfloc alum injection. Lake and Reservoir Management, 25(4), 351-363. http://doi.org/10.1080/07438140903172923

Moore, B. C., Cross, B. K., Beutel, M., Dent, S., Preece, E., \& Swanson, M. (2012). Newman Lake restoration: A case study Part III. Hypolimnetic oxygenation. Lake and Reservoir Management, 28(4), 311-327. http://doi.org/10.1080/07438141.2012.738463

Moore, J. W., Schindler, D. E., Scheuerell, M. D., Smith, D., \& Frodge, J. (2003). Lake Eutrophication at the Urban Fringe, Seattle Region, USA. AMBIO: A Journal of the Human Environment, 32(1), 13-18. http://doi.org/10.1579/0044-7447-32.1.13

National Research Council. (1992). Restoration of aquatic ecosystems: science, technology, and public policy. National Academies Press.

Oberholster, P. J., Botha, A. M., \& Cloete, T. E. (2006). Toxic cyanobacterial blooms in a shallow, artificially mixed urban lake in Colorado, USA. Lakes and Reservoirs: Research and Management, 11(2), 111-123. http://doi.org/10.1111/j.1440- 
1770.2006.00297.x

ODEQ. (2001). Tualatin River Basin Watershed Final TMDL Main Report. Retrieved from http://www.environmental-

engineer.com/permits/docs/tmdl/or_final_tmdl/tualatin/a_tualatin_basin_or_final_t mdl_main_report_2001_sm.pdf

Oksanen, J., Blanchet, G. F., Kindt, R., Legendre, P., O’hara, R. B., Simpson, G. L., ... Wagner, H. (2013). vegan: Community Ecology Package.

Paerl, H. W., Gardner, W. S., Havens, K. E., Joyner, A. R., McCarthy, M. J., Newell, S. E., ... Scott, J. T. (2016). Mitigating cyanobacterial harmful algal blooms in aquatic ecosystems impacted by climate change and anthropogenic nutrients. Harmful Algae, 54, 213-222. http://doi.org/10.1016/j.hal.2015.09.009

Paerl, H. W., \& Huisman, J. (2008). Blooms Like It Hot. Science, 320(5872), 57-58. http://doi.org/10.1126/science. 1155398

Paerl, H. W., \& Paul, V. J. (2012). Climate change: Links to global expansion of harmful cyanobacteria. Water Research, 46(5), 1349-1363. http://doi.org/10.1016/j.watres.2011.08.002

Pan, Y., Guo, S., Li, Y., Yin, W., Qi, P., Shi, J., ... Zhu, J. (2018). Effects of Water Level Increase on Phytoplankton Assemblages in a Drinking Water Reservoir. Water, 10(3), 256. http://doi.org/10.3390/w10030256

Patrick, R., \& Reimer, C. W. (1966). The Diatoms of the United States: Exclusive of Alaska and Hawaii: Fragilariaceae, Eunotiaceae, Achnanthaceae, Naviculaceae Vol. 1. Academy of Natural Sciences of Philadelphia.

Patrick, R., \& Reimer, C. W. (1975). The Diatoms of the United States: Exclusive of Alaska and Hawaii: Entomoneidaceae, Cymbellaceae, Gomphonemaceae, Epithemiaceae Vol. 2. Academy of Natural Sciences of Philadelphia.

Paul, W. J., Hamilton, D. P., Ostrovsky, I., Miller, S. D., Zhang, A., \& Muraoka, K. (2012). Catchment land use and trophic state impacts on phytoplankton composition: A case study from the Rotorua lakes' district, New Zealand. Hydrobiologia, 698(1), 133-146. http://doi.org/10.1007/s10750-012-1147-4

Peterson, D. L., Silsbee, D. G., \& Redmond, K. T. (1999). Detecting long-term hydrological patterns at Crater Lake, Oregon. Northwest Science, 73(2), 121-130.

Pettersson, K. (1998). Mechanisms for internal loading of phosphorus in lakes. Hydrobiologia, 373-374, 21-25. http://doi.org/10.1023/A:1017011420035

Pilgrim, K. M., \& Brezonik, P. L. (2005). Treatment of lake inflows with alum for phosphorus removal. Lake and Reservoir Management, 21(1), 1-9. http://doi.org/10.1080/07438140509354407

Poos, M. S., \& Jackson, D. A. (2012). Addressing the removal of rare species in multivariate bioassessments: The impact of methodological choices. Ecological Indicators, 18, 82-90. http://doi.org/10.1016/j.ecolind.2011.10.008 
Prairie, Y. T., Duarte, C. M., \& Kalff, J. (1989). Unifying Nutrient-Chlorophyll Relationships in Lakes. Canadian Journal of Fisheries and Aquatic Sciences, 46(7), 1176-1182. http://doi.org/10.1139/f89-153

Prescott, G. W. (1975). Algae of the Western Great Lakes Area (Revised). Dubuque: Wm. C. Brown Co.

Prescott, G. W. (1980). How to know the freshwater algae (3rd ed.). Dubuque: Wm. C. Brown, Co.

Qin, B., Zhu, G., Gao, G., Zhang, Y., Li, W., Paerl, H. W., \& Carmichael, W. W. (2010). A drinking water crisis in Lake Taihu, China: Linkage to climatic variability and lake management. Environmental Management, 45(1), 105-112. http://doi.org/10.1007/s00267-009-9393-6

R Development Core Team. (2014). The R Project for Statistical Computing. Vienna: R Foundation for Statistical Computing.

Rapala, J., Sivonen, K., Lyra, C., \& Niemelä, S. I. (1997). Variation of microcystins, cyanobacterial hepatotoxins, in Anabaena spp. as a function of growth stimuli. Applied and Environmental Microbiology, 63(6), 2206-2212.

Reichwaldt, E. S., \& Ghadouani, A. (2012). Effects of rainfall patterns on toxic cyanobacterial blooms in a changing climate: Between simplistic scenarios and complex dynamics. Water Research, 46(5), 1372-1393. http://doi.org/10.1016/j.watres.2011.11.052

Retallack, G. J., \& Burns, S. F. (2016). The effects of soil on the taste of wine. GSA Today, 26(5), 4-9. http://doi.org/10.1130/GSATG260A.1

Reynolds, C. S. (2006). The ecology of phytoplankton. Cambridge University Press.

Reynolds, C. S., Oliver, R. L., \& Walsby, A. E. (1987). Cyanobacterial dominance: The role of buoyancy regulation in dynamic lake environments. New Zealand Journal of Marine and Freshwater Research, 21(3), 379-390. http://doi.org/10.1080/00288330.1987.9516234

Rigosi, A., Carey, C. C., Ibelings, B. W., \& Brookes, J. D. (2014). The interaction between climate warming and eutrophication to promote cyanobacteria is dependent on trophic state and varies among taxa. Limnology and Oceanography, 59(1), 99114. http://doi.org/10.4319/1o.2014.59.01.0099

Robarts, R. D., \& Zohary, T. (1987). Temperature effects on photosynthetic capacity, respiration, and growth rates of bloom-forming cyanobacteria. New Zealand Journal of Marine and Freshwater Research, 21(3), 391-399. http://doi.org/10.1080/00288330.1987.9516235

Rolland, A., Bird, D. F., \& Giani, A. (2005). Seasonal changes in composition of the cyanobacterial community and the occurrence of hepatotoxic blooms in the eastern townships, Québec, Canada. Journal of Plankton Research, 27(7), 683-694. http://doi.org/10.1093/plankt/fbi042 
Roy, A. H., Wenger, S. J., Fletcher, T. D., Walsh, C. J., Ladson, A. R., Shuster, W. D., ... Brown, R. R. (2008). Impediments and solutions to sustainable, watershed-scale urban stormwater management: Lessons from Australia and the United States. Environmental Management, 42(2), 344-359. http://doi.org/10.1007/s00267-0089119-1

Rubenson, R. M. (2016). The Influence of Stormwater Drains and Landscape Characteristics on Phosphorus Loading in an Urban Watershed. Portland State University.

Schindler, D. W. (1977). Evolution of phosphorus limitation in lakes. Science, 195(4275), 260-262. http://doi.org/10.1126/science.195.4275.260

Schindler, D. W. (2012). The dilemma of controlling cultural eutrophication of lakes. In Proceedings of the Royal Society B: Biological Sciences. The Royal Society. http://doi.org/10.1098/rspb.2012.1032

Schindler, D. W., Hecky, R. E., Findlay, D. L., Stainton, M. P., Parker, B. R., Paterson, M. J., ... Kasian, S. E. M. (2008). Eutrophication of lakes cannot be controlled by reducing nitrogen input: Results of a 37-year whole-ecosystem experiment. Proceedings of the National Academy of Sciences, 105(32), 11254-11258. http://doi.org/10.1073/pnas.0805108105

Schindler, D. W., \& Vallentyne, J. R. (2008). The Algal Bowl: Overfertilization of the World's Freshwaters and Estuaries. Edmonton, Alberta: The University of Alberta Press.

Schueler, T., \& Simpson, J. (2001). Introduction: why urban lakes are different. Watershed Protection Techniques, 3(4), 747-750.

Schütz, J. (2016). A comparison of two treatment methods to reduce internal phosphorous cycling in lakes : surface versus injection application. Swedish University of Agricultureal Sciences. Retrieved from https://stud.epsilon.slu.se/8750/19/schutz_j_160223.pdf

Settele, J., Scholes, R. J., Betts, R. A., Bunn, S., Leadley, P., Nepstad, D., ... Toboada, M. A. (2014). Terrestrial and inland water systems. In Climate Change 2014: Impacts, Adaptation, and Vulnerability. Part A: Global and Sectoral Aspects. Contribution of Working Group II to the Fifth Assessment Report of the Intergovernmental Panel on Climate Change (pp. 271-359). Cambridge, United Kingdom and New York, NY, USA: Cambridge University Press,. http://doi.org/31 March 2014

Shapiro, J. (1997). The role of carbon dioxide in the initiation and maintenance of bluegreen dominance in lakes. Freshwater Biology, 37(2), 307-323. http://doi.org/10.1046/j.1365-2427.1997.00164.x

Shapiro, J., Lamarra, V., \& Lynch, M. (1975). Biomanipulation: an ecosystem approach to lake restoration. Water Quality Management through Biological Control. Retrieved from http://www.indiana.edu/ lynchlab/PDF/Lynch2.pdf

Shimoda, Y., Azim, M. E., Perhar, G., Ramin, M., Kenney, M. A., Sadraddini, S., ... 
Arhonditsis, G. B. (2011). Our current understanding of lake ecosystem response to climate change: What have we really learned from the north temperate deep lakes? Journal of Great Lakes Research, 37(1), 173-193. http://doi.org/10.1016/j.jglr.2010.10.004

Smith, G. M. (1950). The Fresh-water algae of the United States. New York: McGrawHill Book Co. Inc.

Soltero, R. A., Sexton, L. M., Ashley, K. I., \& McKee, K. O. (1994). Partial and full lift hypolimnetic aeration of medical lake, WA to improve water quality. Water Research, 28(11), 2297-2308. http://doi.org/10.1016/0043-1354(94)90045-0

Sommer, U., Gliwicz, Z. M., Lampert, W. I., \& Duncan, A. (1986). The PEG-model of seasonal succession of planktonic events in fresh waters. Archiv Fur Hydrobiologie, 106(4), 433-471. http://doi.org/10.1111/j.1469-185X.1969.tb01218.x

Søndergaard, M., Jensen, J. P., \& Jeppesen, E. (2003). Role of sediment and internal loading of phosphorus in shallow lakes. Hydrobiologia, 506(1-3), 135-145. http://doi.org/10.1023/B:HYDR.0000008611.12704.dd

Southwood, T. R. E. (1977). Habitat, the templet for ecological strategies? Journal of Animal Ecology, 46(2), 337-365.

SRI. (1987). Lake Oswego Lake and Watershed Assessment 1986-1987: Diagnostic and Restoration Analysis.

Suikkanen, S., Laamanen, M., \& Huttunen, M. (2007). Long-term changes in summer phytoplankton communities of the open northern Baltic Sea. Estuarine, Coastal and Shelf Science, 71(3-4), 580-592. http://doi.org/10.1016/j.ecss.2006.09.004

Thomas, J. a., Funk, W. H., Moore, B. C., \& Budd, W. W. (1994). Short Term Changes In Newman Lake Following Hypolimnetic Aeration With The Speece Cone. Lake and Reservoir Management, 9(1), 111-113. http://doi.org/10.1080/07438149409354738

Triest, L., Stiers, I., \& Onsem, S. Van. (2016). Biomanipulation as a nature-based solution to reduce cyanobacterial blooms. Aquatic Ecology, 50(3), 461-483. http://doi.org/10.1007/s10452-015-9548-x

Van der Molen, D. T., \& Boers, P. C. (1994). Influence of internal loading on phosphorus concentration in shallow lakes before and after reduction of the external loading. In Nutrient Dynamics and Biological Structure in Shallow Freshwater and Brackish Lakes (pp. 379-389). Dordrecht, The Netherlands: Springer.

Visser, P. M., Ibelings, B. W., Bormans, M., \& Huisman, J. (2016). Artificial mixing to control cyanobacterial blooms: a review. Aquatic Ecology, 50(3), 423-441. http://doi.org/10.1007/s10452-015-9537-0

Walsby, A. E. (1994). Gas Vesicles. Microbiological Reviews, 58(1), 94-144. http://doi.org/10.1146/annurev.pp.26.060175.002235

Ward Jr., J. H. (1963). Hierarchical grouping to optimize an objective function. Journal 
of the American Statistical Association, 58(301), 236-244.

Watson, S. B., McCauley, E., \& Downing, J. A. (1997). Patterns in phytoplankton taxonomic composition across temperate lakes of differing nutrient status. Limnology and Oceanography, 42(3), 487-495.

Wehr, J. D., \& Sheath, R. G. (2003). Freshwater Algae of North America: Ecology and Classification. San Diego: Academic Press.

Welch, E. B., \& Cooke, G. D. (1999). Effectiveness and Longevity of Phosphorus Inactivation with Alum. Lake and Reservoir Management, 15(1), 5-27. http://doi.org/10.1080/07438149909353948

Wetzel, R. G. (2001). Limnology: lake and river ecosystems. Gulf Professional Publishing.

Whitton, B. A., \& Potts, M. (2007). The ecology of cyanobacteria: their diversity in time and space. Springer Science \& Business Media.

Winder, M., \& Schindler, D. E. (2004). Climatic effects on the phenology of lake processes. Global Change Biology, 10(11), 1844-1856. http://doi.org/10.1111/j.1365-2486.2004.00849.x

Winder, M., \& Sommer, U. (2012). Phytoplankton response to a changing climate. Hydrobiologia, 698(1), 5-16. http://doi.org/10.1007/s10750-012-1149-2

Wolter, K. (1989). Modes of Tropical Circulation, Southern Oscillation, and Sahel Rainfall Anomalies. Journal of Climate, 2(2), 149-172.

Wolter, K., \& Timlin, M. S. (1993). Monitoring ENSO in COADS with a Seasonally Adjusted Principal Component Index. In Proc. of the 17th Climate Diagnostics Workshop.

Wolter, K., \& Timlin, M. S. (1998). Measuring the strength of ENSO events: How does 1997/98 rank? Weather, 53(9), 315-324.

Zamparas, M., \& Zacharias, I. (2014). Restoration of eutrophic freshwater by managing internal nutrient loads. A review. Science of the Total Environment, 496, 551-562. http://doi.org/10.1016/j.scitotenv.2014.07.076 
Appendices 


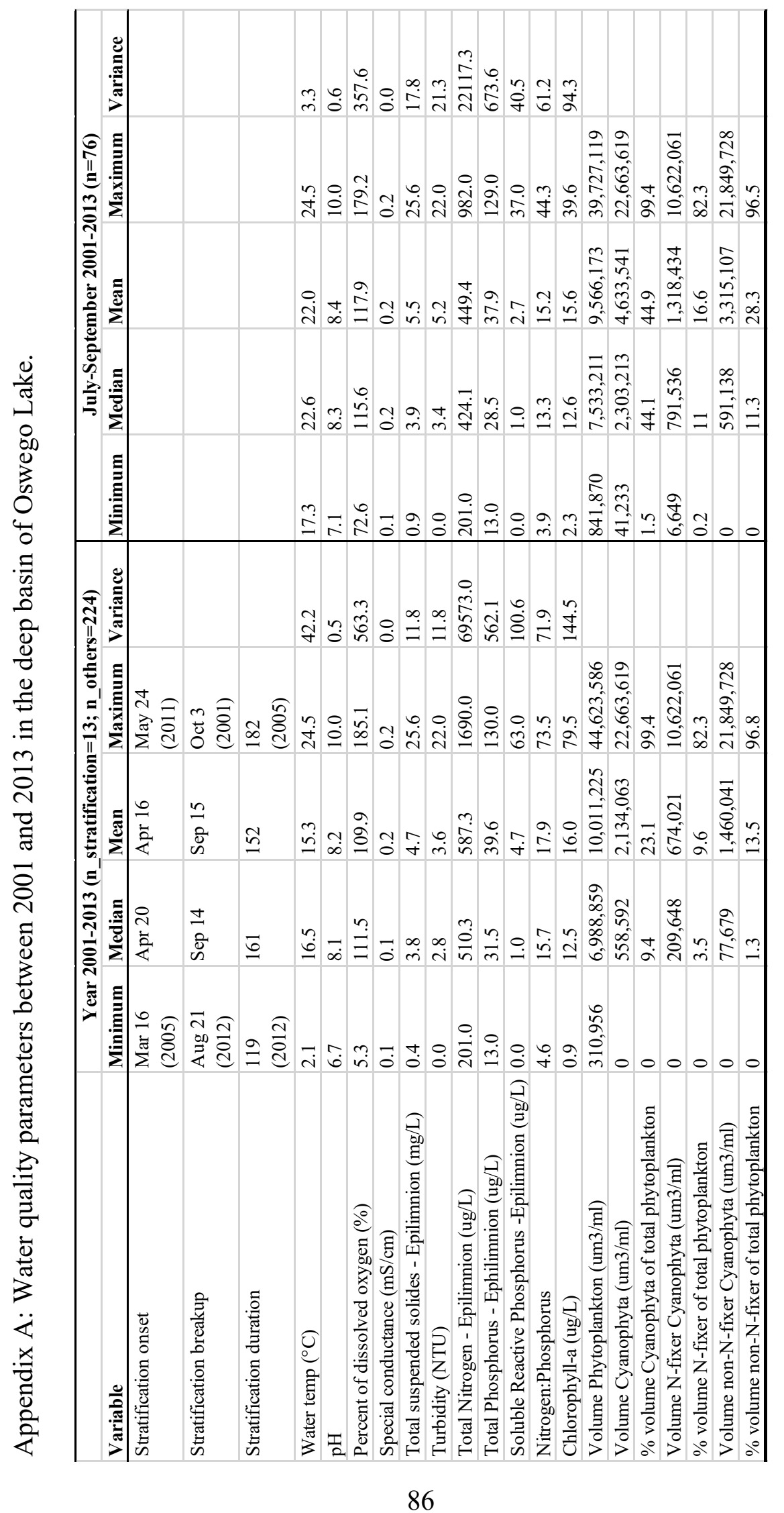


Appendix B: Field sampling and laboratory procedures.

Appendix B1: Total suspended solids

Field sampling

- Use Kemmerer sampler to collect water from specific depth(s)

- Fill $1 \mathrm{~L}$ bottle with sample

- Refrigerate when you return to marina until processing

Preparation of glass fiber filter

- Label aluminum cups, 1-10

- Install aspirator to faucet and connect via hose to flask

- Place rubber stopper end of magnetic filtering stage inside neck of filter flask

- Place glass fiber filter disk (Whatman 934-AH filter) wrinkle side up on filtering stage

- Place magnetic filtering cup over filter

- Turn on water to apply vacuum and wash disk with three successive $20 \mathrm{~mL}$ portions of D.I. water

- Continue vacuum to remove as much water as possible (3 minutes)

- Stop vacuum, remove filtering cup, and use filter forceps to transfer filter from the filtering stage to numbered aluminum cup in drying oven

- Repeat process until 9 filters have been prepared

- Dry in oven at $103^{\circ} \mathrm{C}$ for at least 1 hour

- Turn off oven and allow filter papers to reach room temperature (at least 1 hour, typically 90 minutes)

- Use forceps to move cooled cup and filter from oven to electric balance

- Record start weight on water quality lab worksheet

Filtering sample

- Set up filtering apparatus as outlined above

- Remove filter from aluminum cup and place on filtering stage

- Shake water sample to thoroughly homogenize

- Slowly turn on water to apply vacuum

- Start by pouring $300 \mathrm{~mL}$ of mixed sample into filtering apparatus

- Repeat until flow starts to slow

- Record filtered volume

- Wash graduated cylinder with 3 successive $10 \mathrm{~mL}$ volumes of D.I. water and pour each into filtering apparatus

- Wash interior of filtering cup with one $10 \mathrm{~mL}$ rinse of purified water 
- Continue suction for at least 1-3 minutes after filtration is complete. If the filter is being rewetted from splash back stop the vacuum, remove the stopper and sample from neck of flask, pour out water from flask, replace the stopper and sample, and reapply vacuum to continue filtering

- Stop vacuum, remove filtering cup, and use filter forceps to transfer filter from the filtering stage to original numbered aluminum cup in drying oven

- Repeat process for all samples

- Dry for at least one hour at $103^{\circ} \mathrm{C}$

- Turn off oven and allow filter papers to reach room temperature (at least 1 hour, typically 90 minutes)

- Use forceps to move cooled cup and filter from oven to electric balance

- Record final weight on lab sheet 
Appendix B2: Chlorophyll $a$

\section{Field data collection and filtering}

- Place GN-6 filter2 on filter plate and screw on filter funnel, attach hand vacuum pump to filter apparatus

- Use Kemmerer to collect water from specific depth

- Use graduated cylinder to measure $500 \mathrm{~mL}$ of sample water, add $0.5 \mathrm{~mL}$ saturated magnesium carbonate solution3

- Pour 300-500 mL of sample into filter funnel (volume will depend on particulate concentration)

- Do not exceed a vacuum of 15 inches mercury during filtration

- Rinse graduated cylinder with $10 \mathrm{~mL}$ volume of distilled water and pour into filter funnel

- Rinse walls of filter apparatus with distilled water

- Remove filter from plate with filter forceps, fold into quarters lengthwise and place in centrifuge tube

- Place tubes in cooler with ice pack

- Rinse graduated cylinder and filter apparatus with distilled water after each use

- Collect $1 \mathrm{QA} / \mathrm{QC}$ chlorophyll a sample from Outlet for ARI

- Follow procedures through remove filter from plate with filter forceps

- Place filter (UNFLODED) in sterile petri dish. Label, cover in foil. Ship with other samples to ARI

- Place tubes in a test tube rack and store in marina freezer with caps off under a towel until processed

\section{Laboratory analysis}

- Perform all work in subdued light to avoid chlorophyll degradation

- Fill centrifuge tube to the $10 \mathrm{Ll}$ mark with $90 \%$ aqueous acetone 4

- Sonicate sample for 10 seconds, rest for several seconds, and then sonicate for another 10 seconds

- Place sample in ice water, shaded from the light (under a towel)

- Repeat previous two steps for each sample, wiping off sonicator between samples with $100 \%$ acetone

- Allow samples to steep in ice water for 2 hours

- Remove from ice water and centrifuge samples for 20 minutes

Spectrophotometric Determination of Chlorophyll $a$

- Turn on spectrometer and allow to warm up at least 10 minutes prior to using

- Choose User Programs then Chl a 
- Fill cuvette with $3 \mathrm{~mL} \mathrm{90 \%} \mathrm{aqueous} \mathrm{acetone} \mathrm{and} \mathrm{place} \mathrm{into} \mathrm{spectrometer} \mathrm{well,} \mathrm{frosted}$ sides facing you and black number aligned with well arrow

- Zero spectrometer by pressing Zero. Remove cuvette and place aside for additional zeros

- Pipette $1.5 \mathrm{~mL}$ of $90 \%$ aqueous acetone into the other empty cuvette

- Pipette $1.5 \mathrm{~mL}$ from sample tube into the same cuvette

- This dilutes sample to $19.5 \mathrm{~mL}$ (the filter accounts for an additional $0.5 \mathrm{~mL}$ )

- Agitate cuvette gently then wipe sides with a Kimwipe

- Place cuvette into spectrometer well with the frosted sides facing you

- Press Read, record optical density at $750 \mathrm{~nm}$ and $664 \mathrm{~nm}$ on WQ lab worksheet

- Remove cuvette and add $0.1 \mathrm{~mL}$ ( $\sim 3$ drops) $0.1 \mathrm{~N}$ HCL, agitate gently, and let stand for $90 \mathrm{sec}$ (use timer)

- The sample will be a little cloudy initially, make sure it is completely clear before reading again

- Return cuvette to spectrometer well, frosted sides facing you and black number aligned with arrow

- Press Read, record optical density at $665 \mathrm{~nm}$ and $750 \mathrm{~nm}$ on WQ lab worksheet

- Empty cuvette into waste acetone container and rinse glass cuvette with $100 \%$ acetone

- Repeat for all samples, re-zeroing spectrometer after every three samples using cuvette filled with $3 \mathrm{~mL}$ 90\% aqueous acetone 
Appendix B3: Phytoplankton

\section{Field Collection}

- Collect phytoplankton sample using Kemmerer sampler from designated depth

- Rinse bottle with sample water and fill completely

- Add $3 \mathrm{~mL}$ Lugols solution1 per liter of sample water

- Close tightly and keep in cool, dry location until shipped (marina refrigerator)

\section{Laboratory Procedures}

- Place a GN-6 filter on top of filter apparatus support plate

- Connect tubing to water aspirator and turn water on slowly

- Shake sample water

- Rinse $100 \mathrm{~mL}$ graduated cylinder with sample water

- Shake sample water again

- Fill graduated cylinder with $50 \mathrm{~mL}$ of sample

- Add six drops of lugols to graduated cylinder

- Filter the $50 \mathrm{~mL}$ of sample and lugols

- Place filter paper in tent of aluminum foil labeled with sample location, date, and volume filtered

- Allow filter to dry for at least 2 days

- Place clean slide on paper towel

- Label slide with sampling station, date, and volume filtered (50 mL usually)

- Cut out square from a corner of the filter paper inside the X created by filtering support plate

- Put oil on slide and move around until entire filter paper is covered

- Pop any bubbles formed by oil

- Cover with cover slip

- Paint lots of clear nail polish around edges of cover slip

- Place in cabinet to dry

- Count 80-100 algae by moving frames

- Keep track of number of frames, algal species and power used 
Taxonomic analyses of phytoplankton samples by WES

(WATER Environmental Services, Inc.)

Microscopic methods, provided on 26 February 2013 by Maribeth V. Gibbons, Pres. WATER Environmental Services, Inc.

Phytoplankton identifications, enumerations, and cell volume determinations were made on lake water samples collected by Lake Oswego staff for each study date. All samples were preserved in the field with standard Lugol's (iodine) Solution and kept cool prior to shipping to WATER Environmental Services, Inc. for microscopic taxonomic analyses.

Taxonomic analysis was performed on a single $1.0 \mathrm{~mL}$ subsample of each well-mixed lake sample using a Sedgewick-Rafter counting chamber and Leitz compound microscope (@100X,400X magnification). The subsample volume held within the S-R chamber was allowed to settle for at least 15 minutes prior to microscopic viewing. Initially, the viewing chamber was scanned at low (40X) magnification to confirm an even distribution of algal cells before intensive identification@100 X power. For routinely processed samples, a transect counting methodology was used in which successive horizontal sweeps of the S-R chamber were made under $100 \mathrm{X}$ power so that the entire $1 \mathrm{~mL}$ subsample volume was analyzed. The entire chamber is covered by 11 transects with each transect composed of 28 fields of view, resulting in a total of 308 fields of view. For samples containing high cell densities of the most common form, (i.e., greater than 50 cells/colonies within one transect pass), at least one half of the volume of each $1 \mathrm{~mL}$ subsample was counted, resulting in a total of 154 fields of view. In that case, the entire $1 \mathrm{~mL}$ S-R chamber was also analyzed to enumerate all rare and very large forms, like Ceratium sp. Only algal cells presumed to be alive at the time of sampling (chloroplast reasonably intact in preserved sample) were counted. Replicate subsamples of a single sample selected from a group of 25 samples were analyzed as a statistical check for counting precision (e.g., Coefficient of Variation was sufficiently small). Average counts for each phytoplankton taxon were computed from subsample results, using appropriate multiplying factors if dilutions are necessary. Algal densities were typically reported in natural units as numbers of cells or colonies per $\mathrm{mL}$.

For each sample, cell dimensions of at least 10 organisms of each phytoplankter were computed to obtain average cell volume per taxon based on geometric shape. Cell volumes for each taxon were calculated for each lake sample analyzed. Determination of cell volume dimensions and identifications were made with a calibrated whipple disc at 400X (high dry magnification) using a Palmer-Maloney nannoplankton chamber $(0.1 \mathrm{~mL}$ volume) or at $1000 \mathrm{X}$ (oil emersion). Cell volumes were reported as cubic microns per $\mathrm{mL}$, and were converted to cubic millimeters per liter $\left(\mathrm{mm}^{3} / \mathrm{L}\right)$ for report presentation. Phytoplankton identifications were made to at least genus level wherever possible. 
Species identifications were conducted primarily according to Prescott $(1975,1980)$, Patrick and Reimer (1966, 1975), Smith (1950), and Wehr and Sheath (2003). Recent journal article sources were also consulted for certain Cyanobacterial identifications due to current revisions in the systematics of this group.

Literature Cited

Patrick, R. \& Reimer, C.W. (1966). The diatoms of the United States. Vol. 1. Acad of Nat Sci., Philadelphia. 688 pp.

Patrick, R. \& Reimer, C.W. (1975). The diatoms of the United States. Vol. 2, Part 1. Acad. of Nat. Sci., Philadelphia. 213 pp.

Prescott, G.W. (1975). Algae of the Western Great Lakes Area, Revised edition. Wm. C. Brown Co., Dubuque. 977 pp.

Prescott, G.W. (1980). How to know the freshwater algae, 3rd ed. Wm. C. Brown, Co., Dubuque. 293 pp. 15

Smith, G.M. (1950). The Fresh-water algae of the United States. McGraw-Hill Book Co. Inc. New York. 719 pp.

Wehr, J.D. \& Sheath, R.G. (Eds.). (2003). Freshwater Algae of North America: Ecology and Classification. Academic Press, San Diego. 918 pp. 
Appendix C: Wind rose diagram showing wind speed and wind direction across day time (5am - 9pm) between July and September from 2001 to 2013 at the weather station at Oswego Lake.

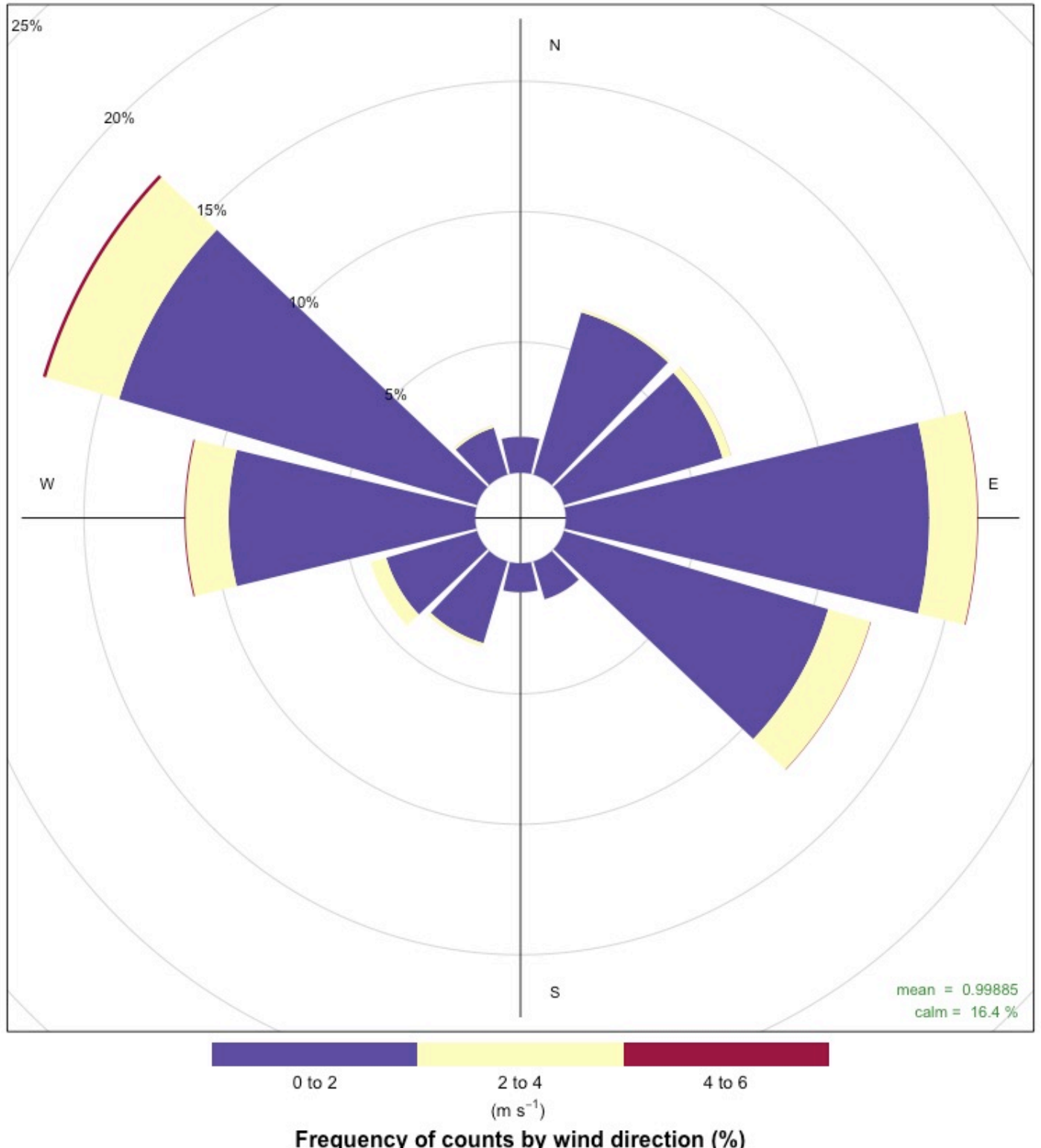

Frequency of counts by wind direction (\%) 
Appendix D: List of phytoplankton taxa and divisions. (The phytoplankton species included in this study were underlined.)

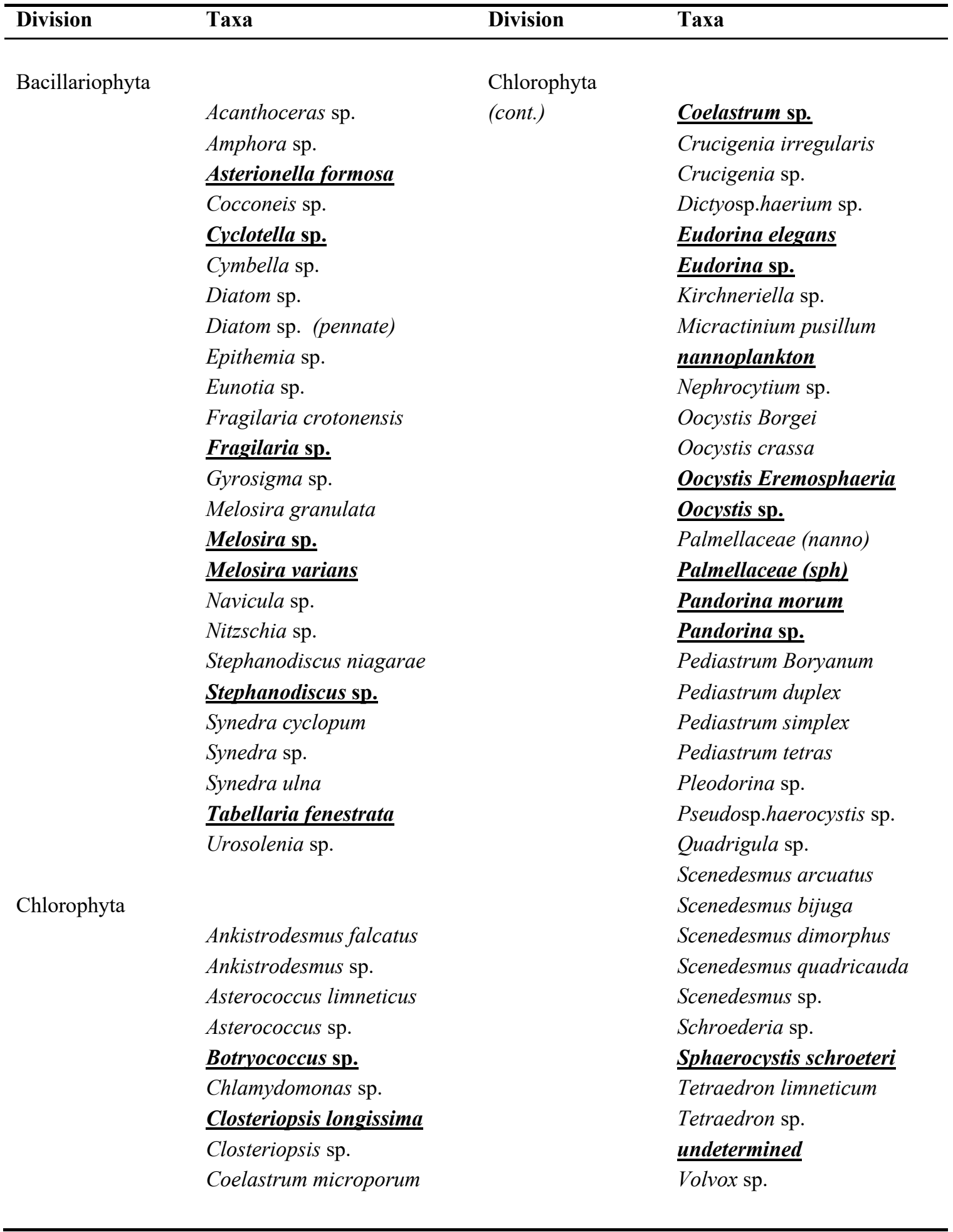


Appendix D: Continued

\begin{tabular}{|c|c|c|c|}
\hline Division & Taxa & Division & Taxa \\
\hline \multirow[t]{17}{*}{ Cyanobacteira } & & Charophyta & \\
\hline & & & Closterium sp. \\
\hline & & & Cosmarium sp. \\
\hline & Anabaena circinalis & & Staurastrum chaetoceros \\
\hline & $\overline{\text { Anabaena flos-aquae }}$ & & Staurastrum paradoxum \\
\hline & $\overline{\text { Anabaena limnetica }}$ & & $\overline{\text { Staurastrum pingue }}$ \\
\hline & Anabaena planctonica & & Staurastrum sp. \\
\hline & Anabaena sp. & & $\overline{\text { Zygnematales }}$ \\
\hline & Anabaena spiroides & & \\
\hline & Aphanizomenon flos-aquae & Chrysophyta & \\
\hline & $\begin{array}{l}\text { Aphanizomenon } \\
\text { issatschenkoi }\end{array}$ & & Chrysophyte (colonial) \\
\hline & Aphanizomenon sp. & & Chrysophyte (filamentous) \\
\hline & Aphanocapsa Grevillei & & Chrysophyte (unicell) \\
\hline & Aphanocapsa sp. & & Dinobryon bavaricum \\
\hline & Gloeotrichia echinulata & & Dinobryon divergens \\
\hline & Nostocaceae & & Dinobryon sp. \\
\hline & & & Mallomonas sp. \\
\hline \multirow[t]{18}{*}{ non-N-fixers } & & & Rhizochrysis limnetica \\
\hline & Anacystis sp. & & Rhizochrysis sp. \\
\hline & Chroococcaceae (colonial) & & Synura sp. \\
\hline & Chroococcus sp. & & \\
\hline & $\begin{array}{l}\text { Coelosp.haerium } \\
\text { Naegelianum }\end{array}$ & Cryptophyta & \\
\hline & $\frac{\text { Coelosphaerium } \mathbf{s p} .}{\text { Cyanophyte (colonia) }}$ & & $\frac{\text { cryptomonad }}{\text { Cryptomonas erosa }}$ \\
\hline & Cyanophyte (unicell) & & $\overline{\text { Cryptomonas ovata }}$ \\
\hline & Gomphosp.haeria lacustris & & Cryptomonas sp. \\
\hline & Gomphosp.haeria sp. & & Rhodomonas sp. \\
\hline & Lyngbya sp. & & \\
\hline & Merismopedia sp. & Euglenophyta & \\
\hline & Microcystis aeruginosa & & Trachelomonas sp. \\
\hline & Microcystis sp. & & Trachelomonas volvocina \\
\hline & $\begin{array}{l}\text { Oscillatoria sp. } \\
\text { Oscillatoriaceae }\end{array}$ & Pyrrophycophyta & \\
\hline & Oscillatoriales & & Ceratium hirundinella \\
\hline & $\overline{\text { Snowella } \mathrm{sp} .}$ & & dinoflagellate \\
\hline & Woronichinia sp. & & Peridiniales \\
\hline & & & Peridinium sp. \\
\hline
\end{tabular}


Appendix E: Phytoplankton relative abundance between July and September from 2001 to 2013 in the deep basin of Oswego Lake.

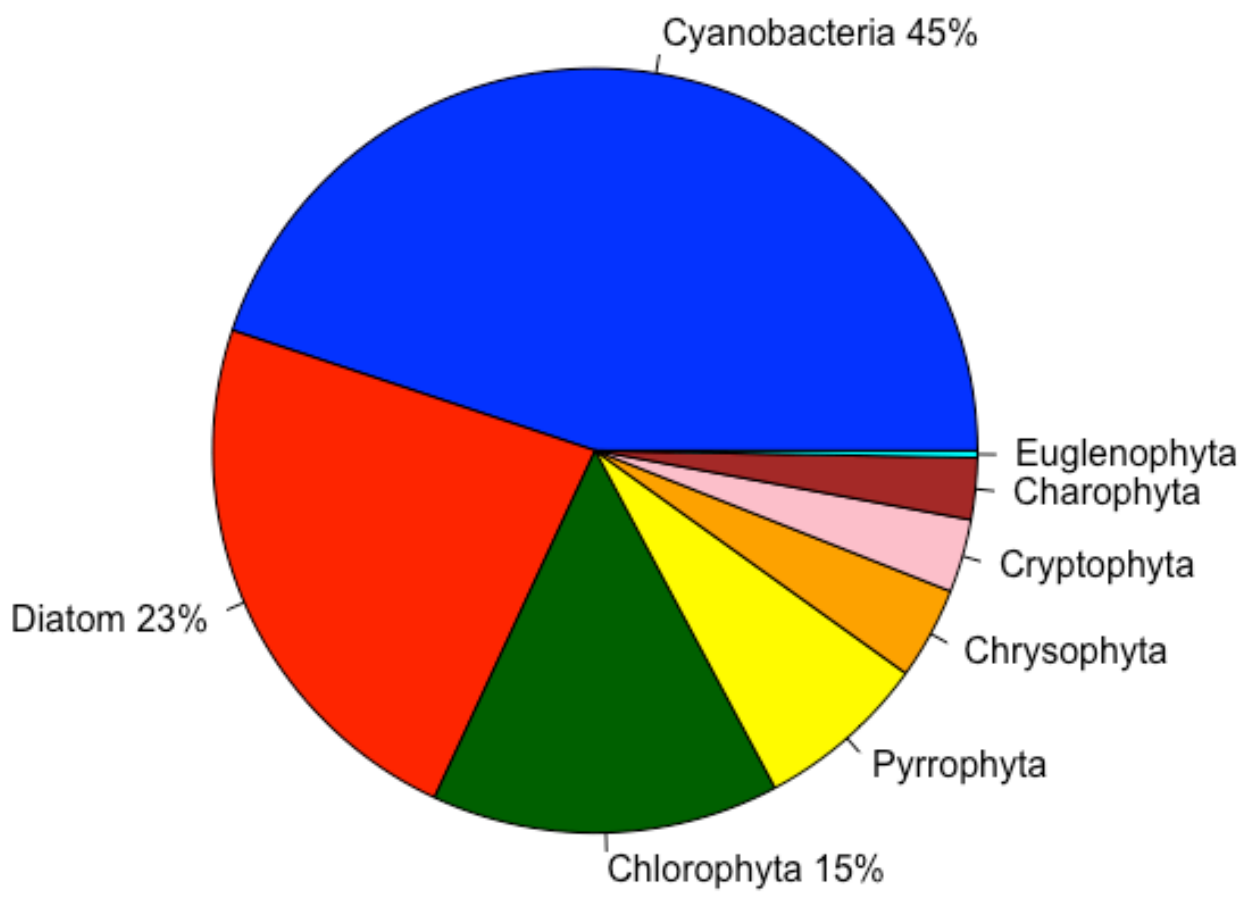


Appendix F: Cluster dendrogram of phytoplankton assemblages showing four groups.

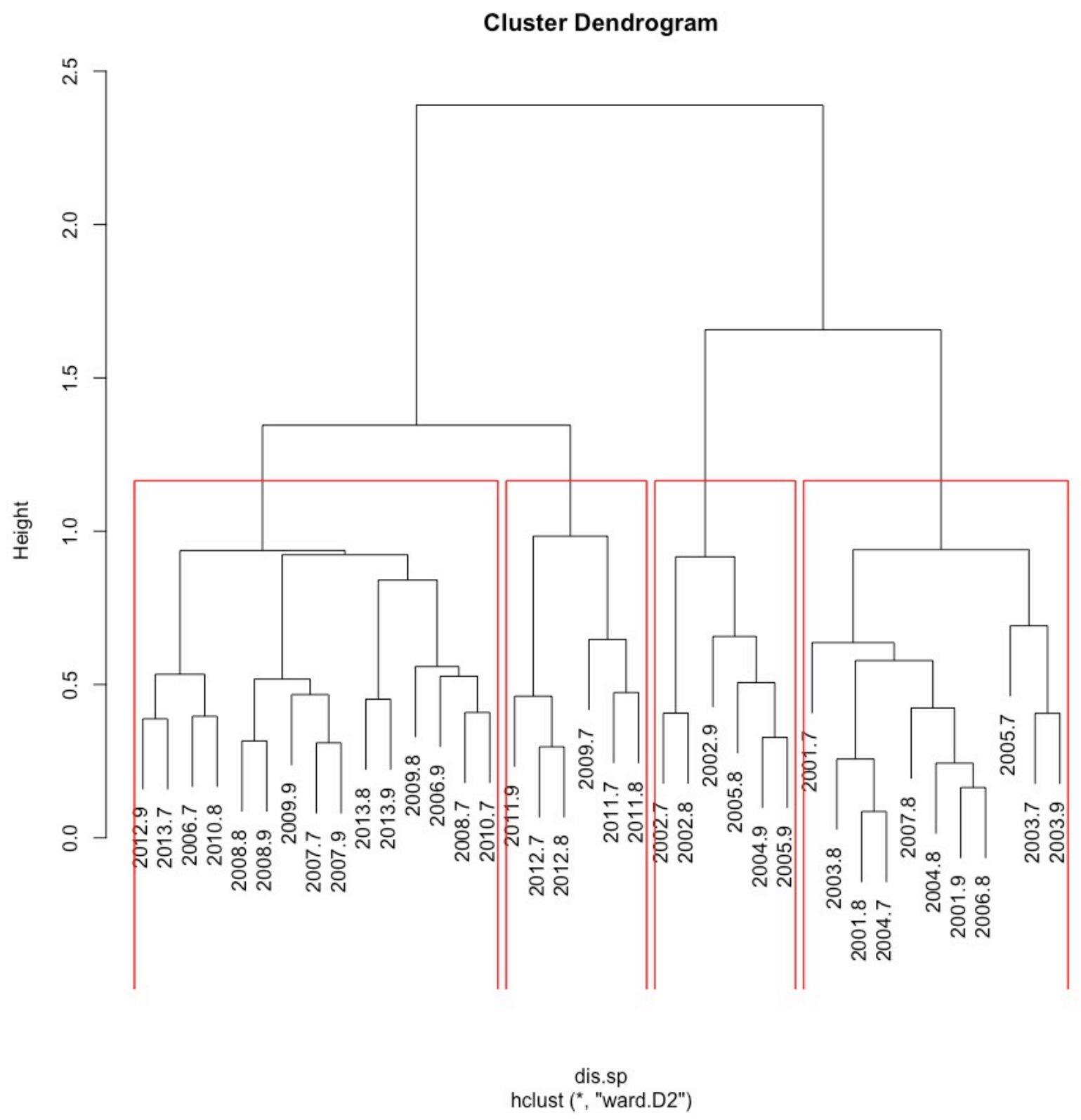


Appendix G: Boxplots showing comparisons of the July-August-September means of epilimnetic TP, SRP and chlorophyll $a$ for pre- and post-initial alum treatment in 2005. All differences were significant $(p<0.05)$ based on Welch Two Sample t-test.

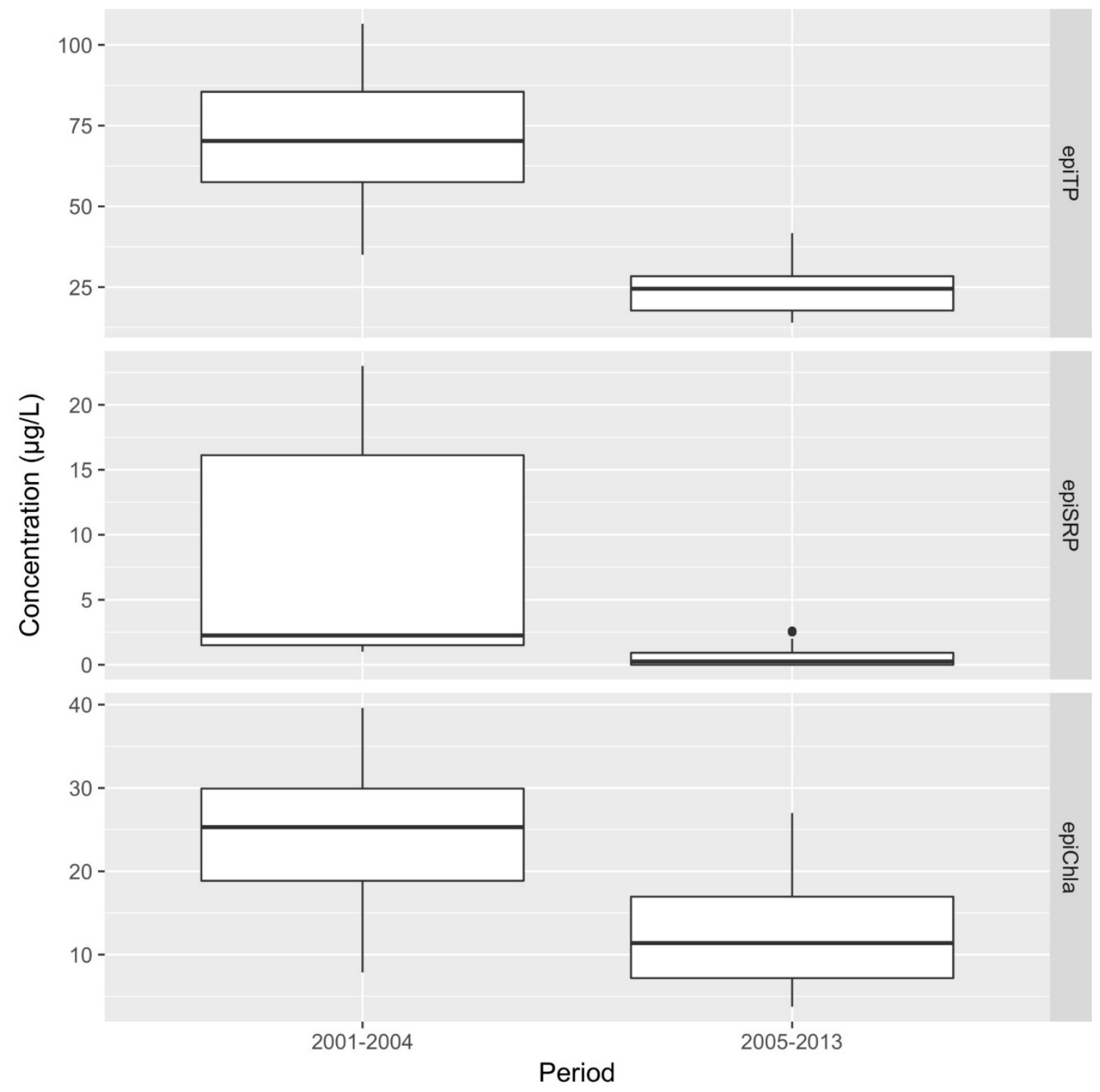


Appendix H: Time series of the multivariate ENSO index (MEI) and Pacific Decadal Oscillation (PDO) index between July and September from 2001 to 2013.

The stacked bar plot of MEI and PDO indices was generated based on Gershunov and Barnett (1998). They demonstrated that PDO seems to have a modulating effect on ENSO teleconnections in North America. They showed that typical El Niño patterns are strong and consistent only during the positive phases of PDO and typical La Niña patterns are consistent only during the negative phases of PDO.

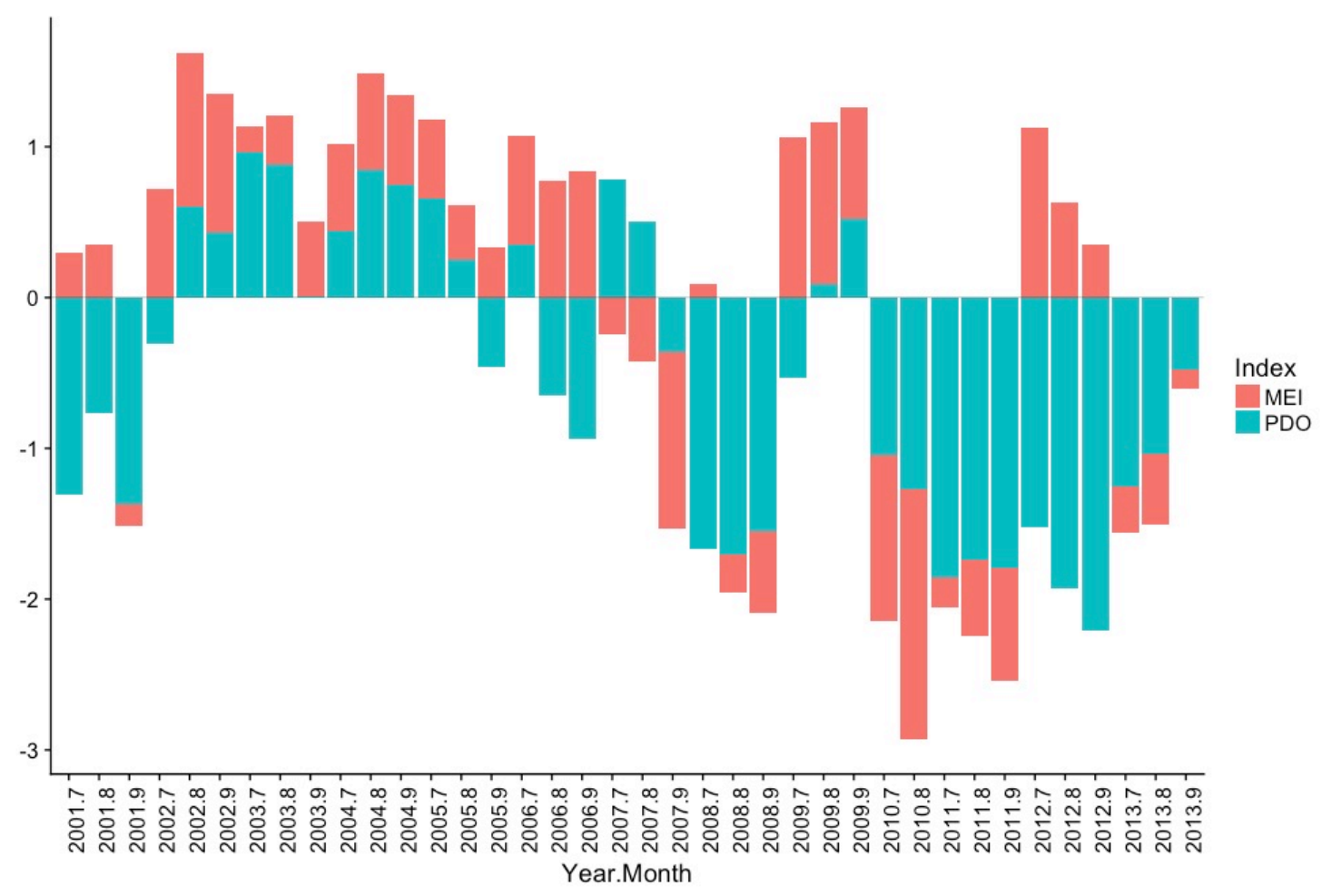

Reference:

Gershunov, A., \& Barnett, T. P. (1998). Interdecadal modulation of ENSO

teleconnections. Bulletin of the American Meteorological Society, 79(12), 2715-2726. 
Appendix I: Time series of the multivariate ENSO index (MEI), showing the study period between 2001 and 2013 and two extreme El Niño events (1997-1998 and 2015-2016).

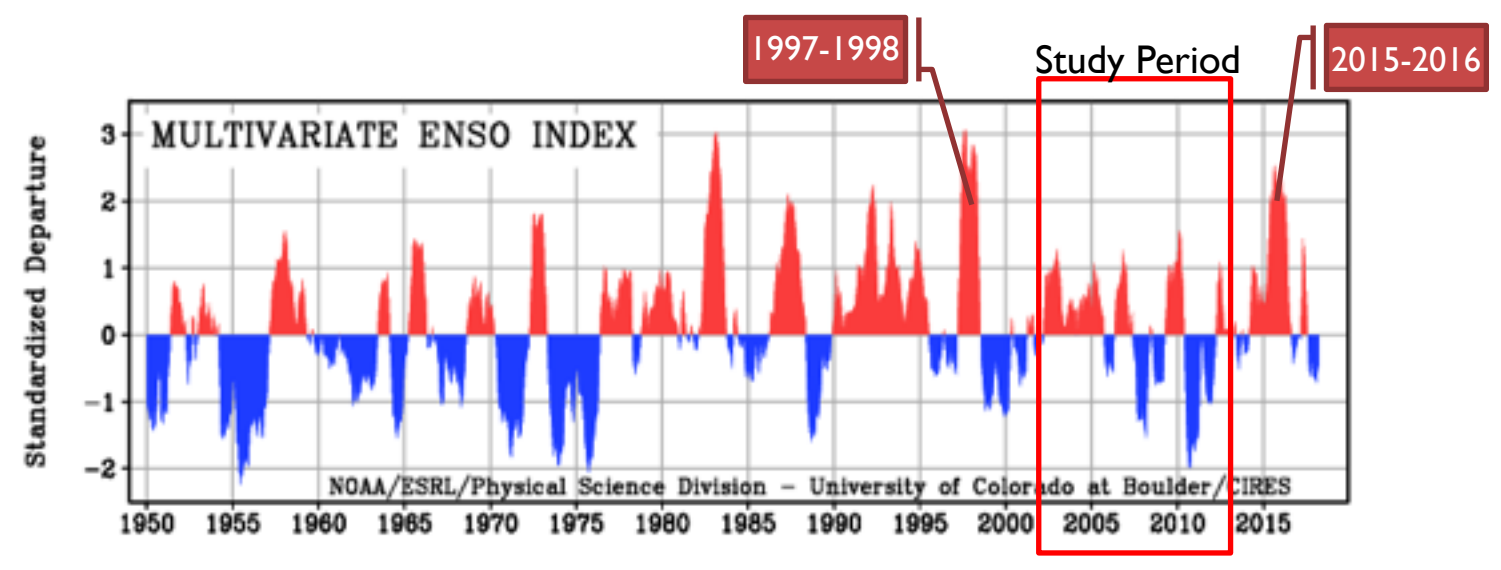


Appendix J: Boxplots of cyanobacteria, epilimnetic water temperature and rainfalls between July and September from 2001 to 2013.

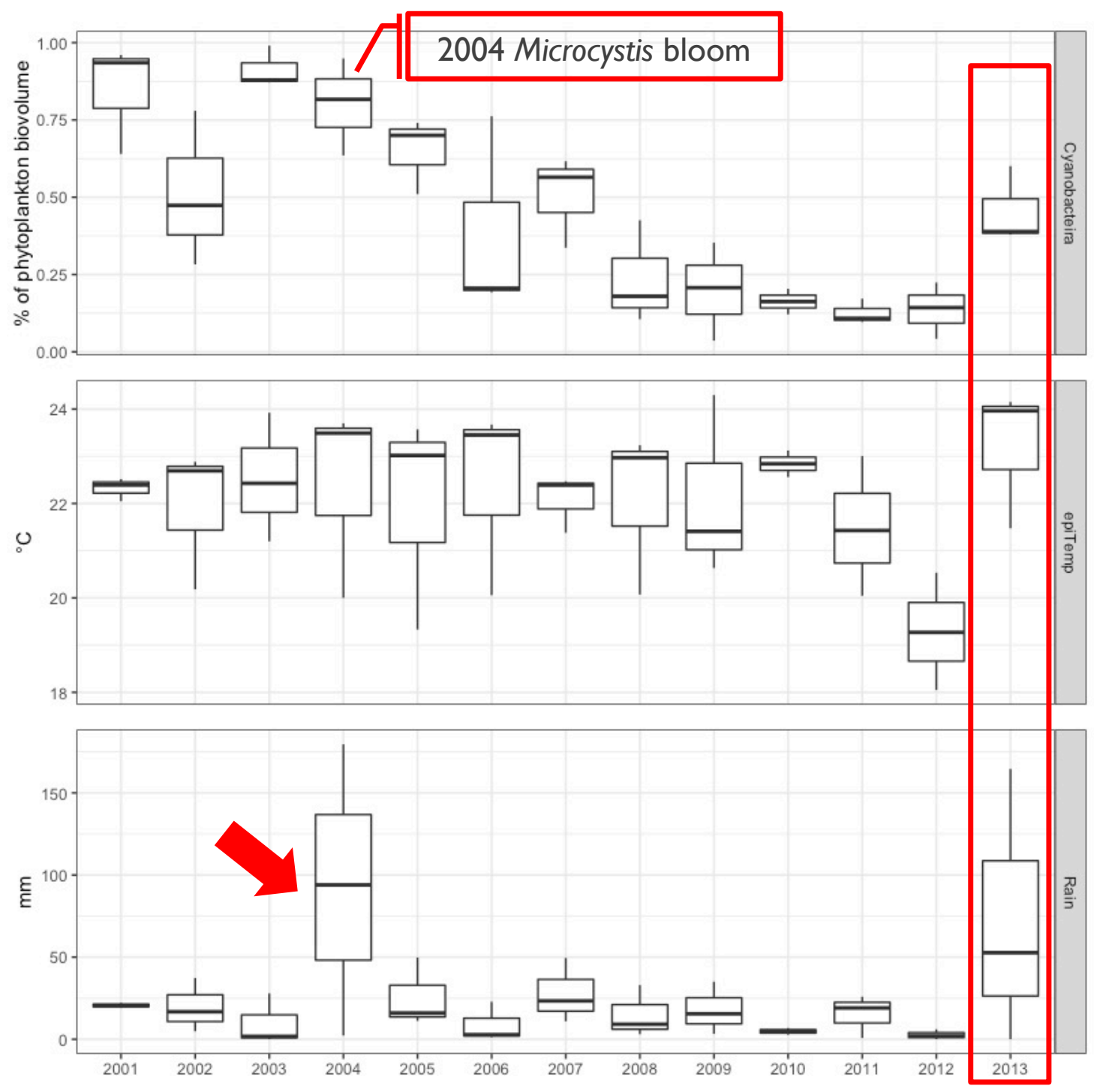

